San Jose State University

SJSU ScholarWorks

Master's Theses

Master's Theses and Graduate Research

Fall 2012

\title{
A descriptive study of old-growth Sequoia sempervirens growth form and canopy structure on a pygmy forest ecotone in Mendocino County
}

Zuhayl Rochin Lambert

San Jose State University

Follow this and additional works at: https://scholarworks.sjsu.edu/etd_theses

\section{Recommended Citation}

Lambert, Zuhayl Rochin, "A descriptive study of old-growth Sequoia sempervirens growth form and canopy structure on a pygmy forest ecotone in Mendocino County" (2012). Master's Theses. 4239. DOI: https://doi.org/10.31979/etd.txz7-5ktw

https://scholarworks.sjsu.edu/etd_theses/4239

This Thesis is brought to you for free and open access by the Master's Theses and Graduate Research at SJSU ScholarWorks. It has been accepted for inclusion in Master's Theses by an authorized administrator of SJSU ScholarWorks. For more information, please contact scholarworks@sjsu.edu. 
A DESCRIPTIVE STUDY OF OLD-GROWTH Sequoia sempervirens GROWTH FORM AND CANOPY STRUCTURE ON A PYGMY FOREST ECOTONE IN MENDOCINO COUNTY

\author{
A Thesis \\ Presented to \\ The Faculty of the Department of Environmental Studies \\ San José State University \\ In Partial Fulfillment \\ of the Requirements for the Degree \\ Master of Science
}

by

Zuhayl Rochin Lambert

December 2012 
(C) 2012

Zuhayl Rochin Lambert

ALL RIGHTS RESERVED 
The Designated Thesis Committee Approves the Thesis Titled

\title{
A DESCRIPTIVE STUDY OF OLD-GROWTH Sequoia sempervirens GROWTH FORM AND CANOPY STRUCTURE ON A PYGMY FOREST ECOTONE IN MENDOCINO COUNTY
}

by

Zuhayl Rochin Lambert

\begin{abstract}
APPROVED FOR THE DEPARTMENT OF ENVIRONMENTAL STUDIES
SAN JOSE STATE UNIVERSITY
\end{abstract}

December 2012

Dr. William Russell

Dr. Rachel O’Malley

Dr. Susan C. Lambrecht
Department of Environmental Studies

Department of Environmental Studies

Department of Biological Science 


\section{ABSTRACT \\ A DESCRIPTIVE STUDY OF OLD-GROWTH Sequoia sempervirens GROWTH FORM AND CANOPY STRUCTURE ON A PYGMY FOREST ECOTONE IN MENDOCINO COUNTY}

by Zuhayl Rochin Lambert

The tallest tree in the world is the coast redwood, Sequoia sempervirens, a species endemic to a 16-km-wide coastal belt extending from Big Sur, California, to southern Oregon. Old-growth redwood forests are home to other plant and animal species that depend on structural characteristics that have formed over hundreds of years. While a great deal of research regarding growth form and structure has taken place on highly productive stands, little work has been done on marginal sites, where redwoods are on the edge of their ecological tolerance. In the Northern California County of Mendocino, hydrophobic spodosol are host to endemic and adapted species called "pygmy." Such species include the rare bolander pine (Pinus contorta spp. bolanderi), pygmy cypress (Cupressus pygmaea), and a number of Ericaceous shrubs. However, the coast redwood has also been observed growing in this soil type.

Using previous soil and vegetation characterizations across the ecotone of the pygmy forest, this study focused on the structural characteristics of Sequoia sempervirens in a stunted stand of old-growth coast redwood in Mendocino County, California. Stepwise linear regression analysis showed total tree height and size to be correlated with soil nutrient levels as expected, but the number of epiphytes in the canopy of pygmy coast redwoods was not correlated with canopy complexity as expected. Instead, epiphyte abundance was significantly correlated with fire hollow volumes, suggesting fire to be a factor in canopy plant communities. 


\section{ACKNOWLEDGEMENTS}

First and foremost, I would like to thank my husband, Matthew Lambert, who spent countless hours in the field carrying heavy equipment, crawling through thick vegetation, climbing to the very top of the tallest trees, taking notes on the ground and in the canopy, and challenging me throughout the research. His help also extended outside the field by providing excellent editing skills and analysis. The help he has provided throughout this project is endless, and there is not enough praise to fully describe his support throughout the entire graduate research process.

I would also like to thank Gregory Eugene McKenna for being such a patient and graceful tree-climbing mentor. He excitedly jumped into the research project without expecting to be compensated, and his excitement continued throughout the field season. His ability to ease my very first repel from $30 \mathrm{~m}$ exemplified his pure love for the skill. I am very grateful to have had such a skilled, fun, loving field assistant during the treeclimbing phase of the project.

I am grateful for my committee members. First, I would like to thank Dr. Will Russell for guiding my research and providing valuable advice during the thesis process. His overwhelming wisdom established a high standard during my graduate research project and academic process. Dr. Rachel O’Malley guided me through the development of the project's methods and statistics. Dr. Susan Lambrecht introduced me to California's plants communities, enthusiastically provided academic and research advice, and field equipment. 
Also, I would like to thank the Michael Lee Environmental Foundation Board Members for encouraging environmental awareness through education and imperative research. The awarded scholarship assisted me to pay for essential research expenses, however, most importantly it inspired me to continue promoting environmental stewardship.

Lastly, I would like to thank Maribel Zarate for cheerfully and gracefully assisting me during the wettest weekend of the field season, and Elizabeth Lanham for generously providing her credentialed skills in GIS. Christopher P. Lee for lending his imaging skills. Athena, the faithful canine, who steadfastly kept watch of the equipment during field days that were spent in the canopy, and for bringing excitement to the project.

But I am most thankful for the pygmy Sequoia sempervirens. During my data collection, their quiet yet strong presence made me feel at ease, and gave a sense security and purpose. Their tenacity to establish themselves in such edaphic environments goes to show that there are no limits in life. 


\section{TABLE OF CONTENTS}

Page

List of Tables ix

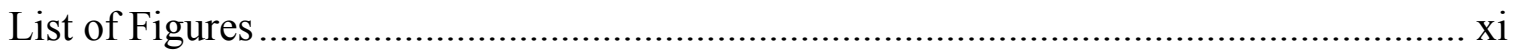

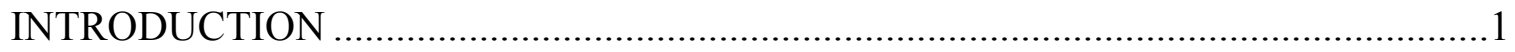

Motivation..............................................................................................

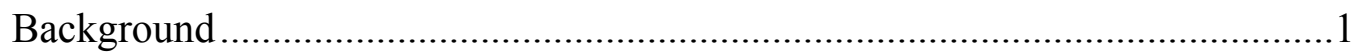

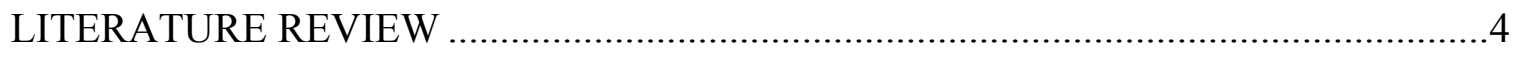

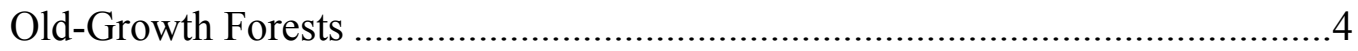

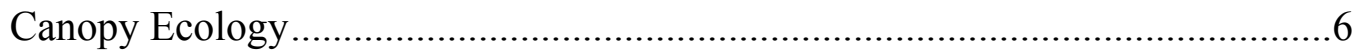

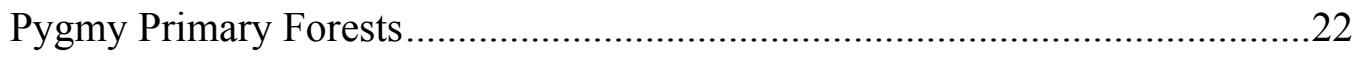

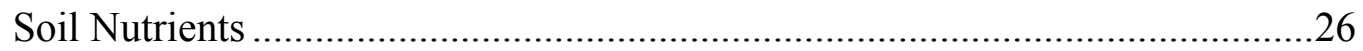

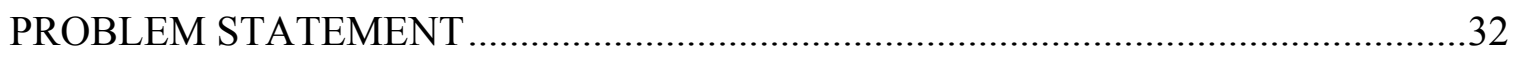

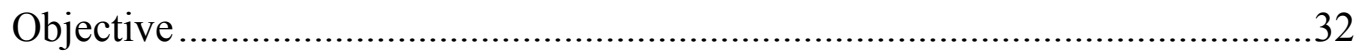

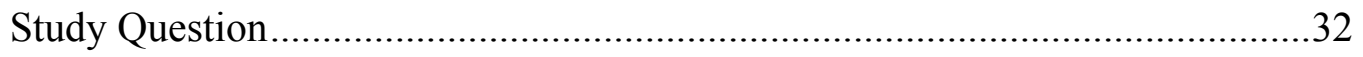

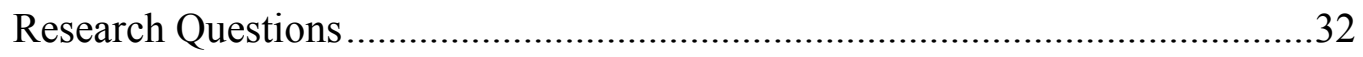

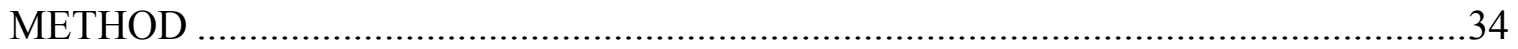

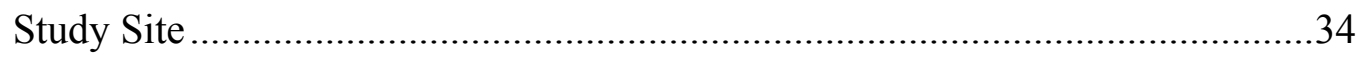

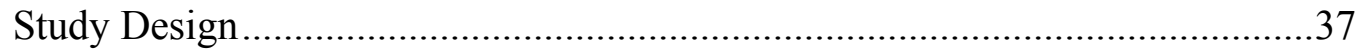

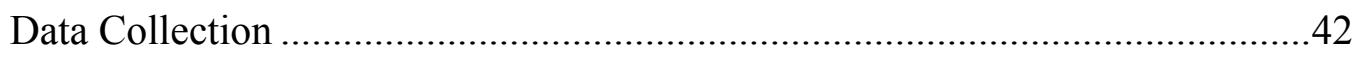

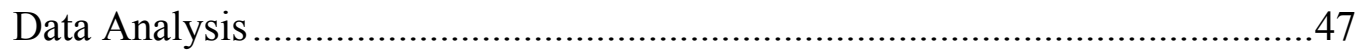

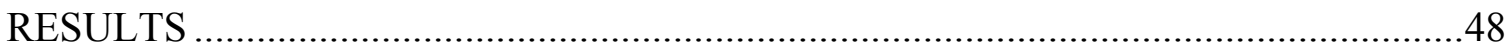

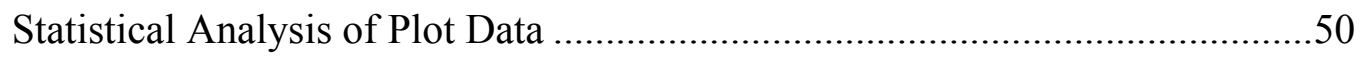




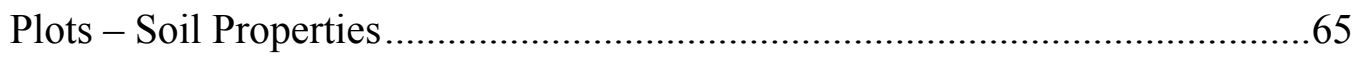

Individual Plot Descriptions - Structural Characteristics.....................................69

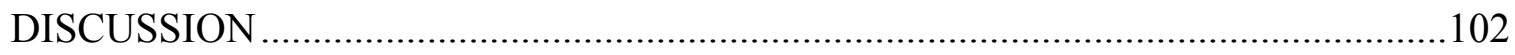

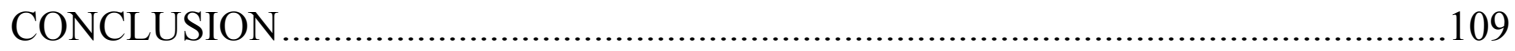

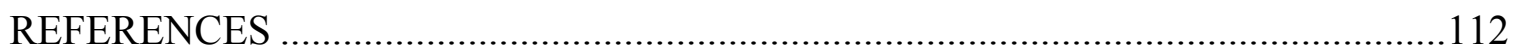

APPENDIX A: Pearson's Correlation with Maximum Height and Soil

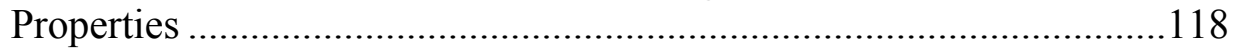

APPENDIX B: Pearson's Correlation with Maximum DBH and Soil

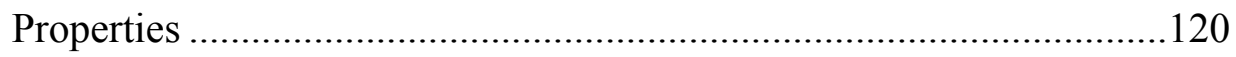

APPENDIX C: Pearson's Correlation with Stand Density and Soil Properties ..............122

APPENDIX D: Pearson's Correlation with Fire Hollow Volume, Soil

Properties, and Tree Structures .........................................................124

APPENDIX E: Pearson's Correlation with Canopy Complexity, Soil

Properties, and Tree Structures .........................................................127 


\section{LIST OF TABLES}

Page

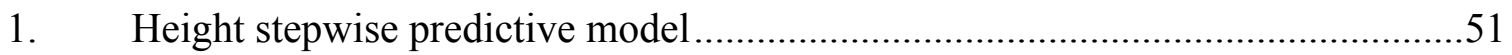

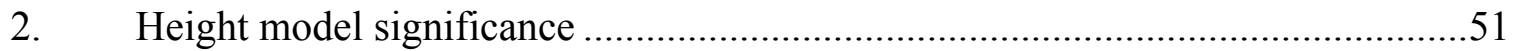

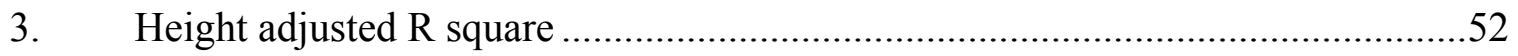

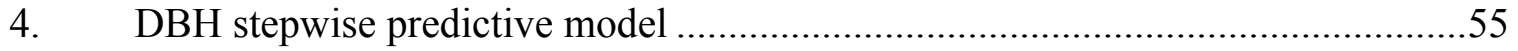

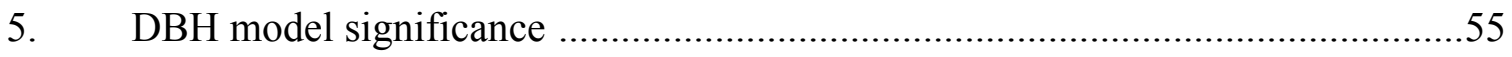

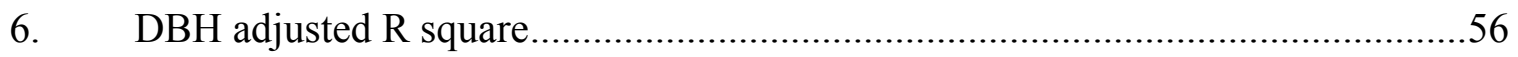

7. Number of stems per plot stepwise predictive model ....................................58

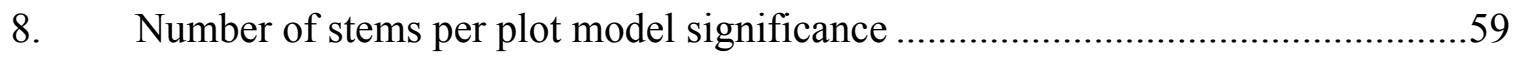

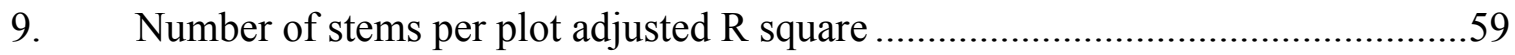

10. Pearson's correlation between number of epiphytes, fire hollows, canopy complexities, and maximum $\mathrm{DBH}$ and tree height .........................................63

11. Epiphytes stepwise predictive model.......................................................64

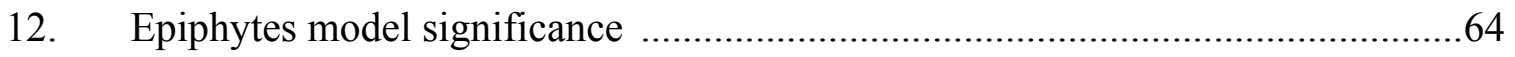

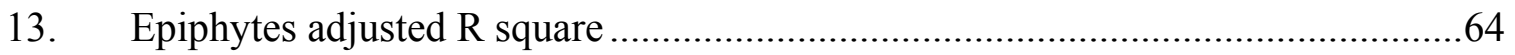

14. Cation exchange capacity and percent cation saturation in the 16 sampled plots .66

15. Levels of soil nutrients and percentage of water holding capacity in the 16 sampled plots

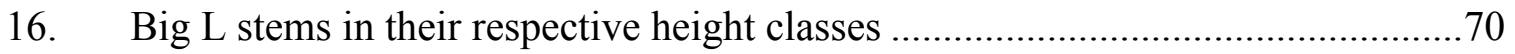

17. Structural characteristics of 16 stems within the FG plot ................................ 71

18. ABC stems structural characteristics in the extreme pygmy stratum ..................74 


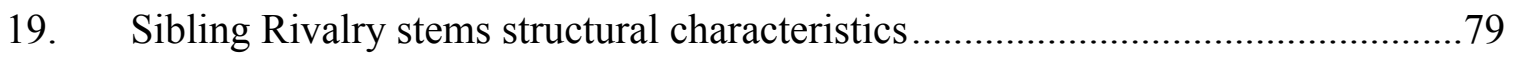

20. YO canopy complexity at the edge of the short and tall pygmy strata ................81

21. Chuy, Hans, and R2 structural characteristics within the YG plot ......................81

22. McKenna Grove stems in respective height classes within the tall pygmy

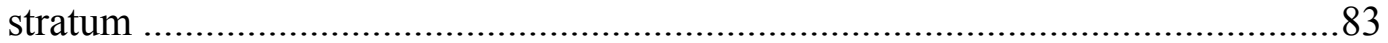

23. Hogs Grove stems in respective height classes within the tall pygmy stratum .....84

24. Santa Barbara stems in respective height classes in the tall pygmy stratum .........86

25. Charles Grove stems in respective height classes within the tall pygmy stratum

26. Louie hierarchical ranks within the Russell Grove in the transitional stratum......89

27. Umbrella Grove stems structural characteristics in the transitional stratum .........91

28. Inish Man approximate hierarchical ranks in the pygmy redwood stratum .........95

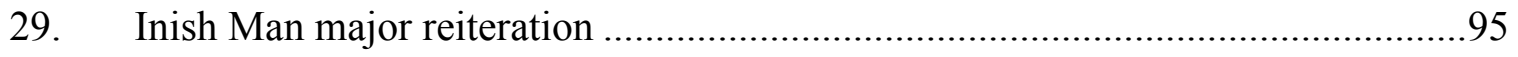

30. El Patron hierarchical ranks in the pygmy redwood stratum .............................96

31. Owl Tree approximate hierarchical ranks in the pygmy redwood stratum...........99

32. Athena hierarchical ranks at the edge of the pygmy redwood stratum...............100 


\section{LIST OF FIGURES}

Page

1. Ecological staircase in Mendocino County from west to east ...........................25

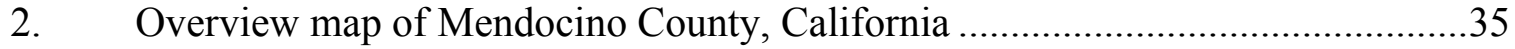

3. Map of the forest age classes and pygmy forest in the Russell Unit of the

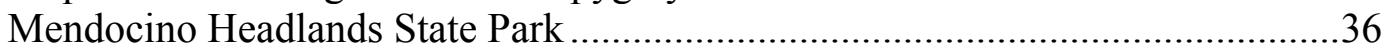

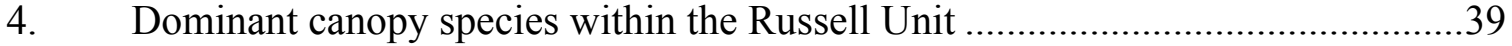

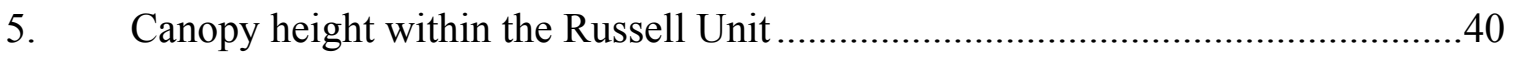

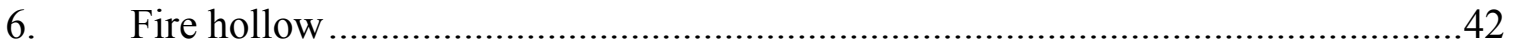

7. Map of 16 sampled plots within the Russell Unit...........................................49

8. Tree height and potassium stepwise linear regression partial scatter plot ............52

9. Tree height and water-holding capacity stepwise linear regression partial

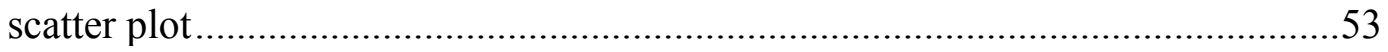

10. $\mathrm{DBH}$ and phosphorous stepwise linear regression partial scatter plot..................56

11. DBH and cation exchange capacity stepwise linear regression partial

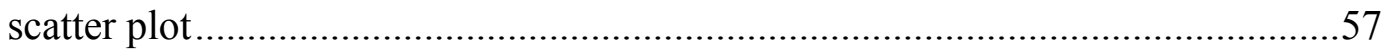

12. Number of stems per plot and maximum height simple scatter plot ...................60

13. Number of epiphytes and fire hollow volume simple scatter plot ......................65

14. Water-holding capacity histogram with normality distribution curve ..................68

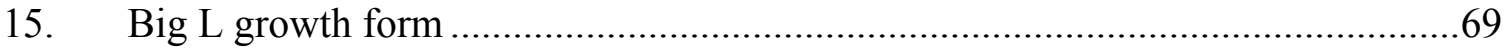

16. Big L stems in the extreme pygmy stratum with organic layer to scale ...............70

17. Seedling BO structural growth form within the FG plot in the extreme pygmy stratum

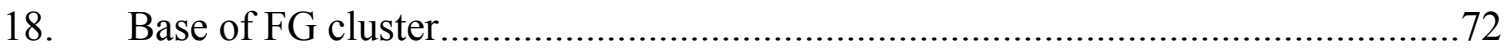


19. Stem map for the ABC cluster in the extreme pygmy stratum ............................75

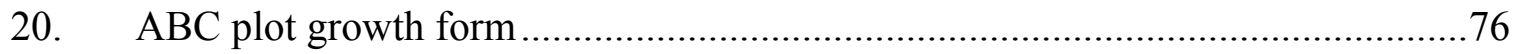

21. Vagabond plot in the short pygmy stratum ................................................ 77

22. Sibling Rivalry burl in the short pygmy stratum ........................................ 78

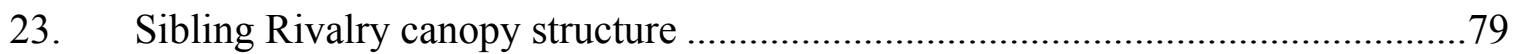

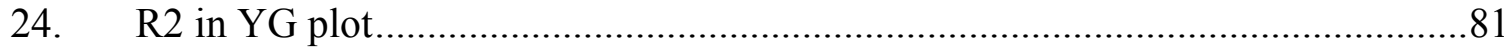

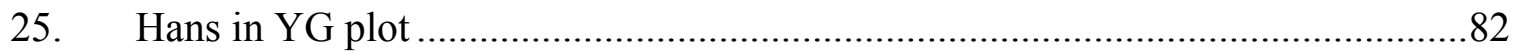

26. Epiphyte in Hogs Grove plot on main trunk within the tall pygmy stratum .........85

27. Santa Barbara stems' structural characteristics in the tall pygmy stratum ...........86

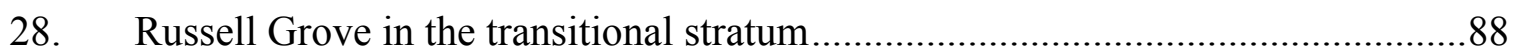

29. Aerial view of tree $\mathrm{F}$ in Umbrella Grove within transitional stratum..................90

30. Trees $\mathrm{E}$ and $\mathrm{F}$ in Umbrella Grove within transitional stratum.............................90

31. Inish Man fire hollow within pygmy redwood stratum .................................92

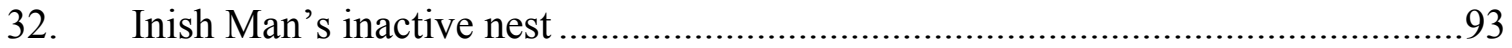

33. Leather fern (Polypodium scouleri) established on decaying limb in the canopy of Inish Man

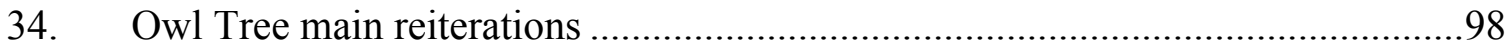

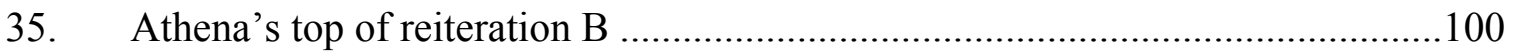

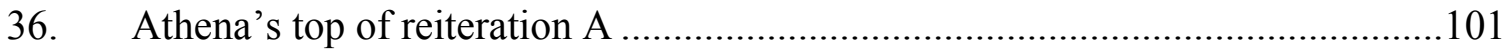




\section{INTRODUCTION}

\section{Motivation}

Old-growth Sequoia sempervirens forests form a unique ecosystem limited to the coastal fog belt in Northern California. Coast redwoods (henceforth in this document coast redwood and S. sempervirens will be used interchangeably) vary in size and structure within the range of the ecosystem, as well as within individual stands. Unusual structural characteristics, including reiterated trunks, large lateral branches, and fire hollows, support unique flora and fauna throughout the tree's several hundred-year lifespan. The habitats created by these structures contribute to the nesting and shelter of approximately 42 different threatened species, including the marbled murrelet (Brachyramphus marmoratus), spotted owl (Strix occidentalis caurina), and northern red-legged frog (Rana aurora aurora). Each of these species is on the brink of extinction due to the rapid disappearance of old growth habitats, resulting from timber harvesting management practices, and land conservation organizations promoting thinning to restore old-growth habitats. It is estimated that approximately $3-5 \%$ of original old-growth redwood forest remains. The goal of this research was to increase the level of knowledge concerning the rarest pockets of this quickly disappearing ecosystem, so that what is left can be managed and protected properly.

\section{Background}

The coast redwood is a species with fossil records dating back to the late Jurassic period, 208 million years ago (Sawyer et al., 2000a). During the Miocene epoch, 23.7 million years ago, the coast redwood distribution was widespread in the northern 
hemisphere (Sawyer et al., 2000a). With climate changes and tectonic movement, the species became endemic to a $16.1 \mathrm{~km}$-wide belt extending from Big Sur, California to Southern Oregon (Johnston, 1994). Recent studies demonstrate that the coast redwood belt is diminishing at its southern edge and expanding in the northern region (Sawyer et al., 2000a). Furthermore, coast redwoods tend to be more productive in inland canyons due to intolerance to coastal salt spray near the ocean. The fog formed along the coast travels through these canyons where the coast redwood has developed a dependency on fog for water availability during dry periods (Dawson, 1998). Dawson's (1998) study demonstrated that about $34 \%$ of water input in coast redwood forests comes from fog interception from the redwood canopy. Nevertheless, only 3-5\% of the primary oldgrowth coast redwood forest remains as a result of logging and development (Russell \& Hageseth Michels, 2010; U.S. Department of Agriculture, 2003).

In addition, the coast redwood's increase in wood production continues through maturity. Sillett et al. (2010) have demonstrated that coast redwood increases in wood production through maturity, with continuous wood production even in the oldest and largest redwood stands. In Northern California, research projects have been carried out to understand the structural characteristics that make old-growth coast redwood canopy forests appealing to a number of different species (Sillett \& Van Pelt, 2000a; Van Pelt \& North, 1996). These studies focused either on single trees or on a larger distribution of trees in old-growth forests on productive slopes or alluvial flats.

In Northern California, near old-growth stands of S. sempervirens, an edaphic formation known as spodosol is found. This substrate is poor in nutrients and highly 
acidic, and its drainage is slow. Endemic and locally adapted dwarf species referred to as "pygmy" occupies this soil type. Some of the species include bolander pine (Pinus contorta spp. bolanderi), pygmy cypress (Cupressus pygmaea), and a number of Ericaceous shrubs (Northup, Dahlgren, \& Yu, 1995; Westman, 1975; Westman \& Whittaker, 1975). On occasion, coast redwoods have been observed growing within the pygmy forests. Westman and Whittaker (1975) studied the productivity of plants inhabiting pygmy forests and adjacent communities, including the coast redwood, from five different areas in Northern California. Their research described the basal area, total canopy cover, and tree density in pygmy forests; however, the canopy characteristics were not considered.

This study is, thus, the first to carefully examine a range of coast redwood canopy structures from extreme pygmy forests across the ecotone to an old-growth pygmy $S$. sempervirens forest. It adds critical information to help understand coast redwood adaptation and reaction to extreme soil conditions, the ability to support epiphytic plants, and the potential to shelter canopy dwelling fauna. 


\section{LITERATURE REVIEW}

\section{Old-Growth Forests}

Limited suitable habitats make the coast redwoods highly susceptible to destructive anthropogenic activities, such as logging and development, especially in oldgrowth forests. Old-growth coast redwood forests are homes to species dependent on characteristics that form only over hundreds of years. Spies and Duncan (2009) describe changing definitions of the term "old-growth." Originally the term was used to describe a forest that had never experienced anthropomorphic activity, such as logging (Frelich \& Reich, 2003; Helms, 2004; Spies \& Duncan, 2009). Subsequently, some ecologists have defined it as a forest with heterogeneous canopy structures and in the mature stages of development (Spies \& Duncan, 2009). Frelich and Reich (2003) disagree with the latter definition because it disregards the importance of natural disturbances and colonizing young stands during the process of succession.

Frelich and Reich (2003) suggest the term "primary forest" for stands that have experienced natural disturbances and reproduction cycles without the involvement of humans. Frelich and Reich further assert that any definition using process-based and physical characteristics is essential. Helms (2004) explains the definition for old-growth changes when referring to specific trees, stands, or a particular forest. The life expectancy of a dominant species is also important when defining old-growth due to the high variability of life expectancy among vascular plants (Helms, 2004). For example, an alder can live up to 100 years, whereas the oldest living tree of any species is a bristlecone pine, at approximately 4,500 years old. Furthermore, the dominance of long- 
lived and short-lived species alternates during succession. Shade-intolerant species dominate a stand after disturbance; however, after several years, shade-tolerant species can out-compete the latter and become dominant (Frelich \& Reich, 2003). In Minnesota, USA, for example, the Department of Natural Resources defines old-growth as a stand of long-lived species, 120 years or older, dominating the landscape. A shade-intolerant stand of red pine can dominate for 120 years and more, but after 180 years, the shortlived shade-tolerant balsam fir begins to dominate the landscape, thus changing the oldgrowth status of the area. Frelich and Reich use this situation to illustrate how relying on age poses a conflict in forest management practices because it fails to take into account natural stand development and succession.

Helms (2004) also discusses influences of the tree species size. Old-growth trees adapted to soils with low nutrient availability display dwarfism, as in the case of the pygmy forest. In this case, the correlation between large wood volume and old-growth is invalid. Frelich and Reich (2003) support Helms's argument, because, ecologically, tree stature depends on the length of dry and wet seasons, and it can also be correlated with latitude and altitude.

An additional definition of old-growth involves the prevalence of complex canopy characteristics. Helms (2004) explains that using canopy characteristics to define oldgrowth is a way to avoid definitions that identify an old-growth stand as a set number of trees per plot. The latter method is mostly used in stands that have experienced logging activity, and the primary goal is to increase wood volume by thinning dense forest stands to reduce competition (Hayes et al., 1997). In the coastal redwood belt, old-growth coast 
redwood forests are defined by their canopy structure, presence of epiphytic vascular plants, and the vertebrate species dwelling in the canopy (Sillett \& Van Pelt, 2000a, 2000b, 2007; Spickler et al., 2006). Large lateral branches, trunk reiterations, established epiphytic vascular plants on developed arboreal soils, and birds and other vertebrates inhabiting coast redwood canopies are features researchers have commonly found in oldgrowth coast redwood trees (Sawyer et al., 2000c). Although the definition of old growth varies, for the purpose of this study, the term "old-growth" and primary forest will be used interchangeably.

\section{Canopy Ecology}

The term ecology was first used and defined in 1935 by A. G. Tansley, a British ecologist, who looked at a wide range of analyses from the sequence of events in the evolutionary processes of plants and animals to links between species (Lowman \& Rinker, 2004). Early research documented tree canopy simply as the top layer of the forest (Nadkarni, Parker, Rinker, \& Jarzen, 2004). With an increase in canopy research, the definition expanded to encompass the ecological sub-system that creates microhabitats for plants, vertebrates, and invertebrates (Nadkarni et al., 2004).

Since the 1970s, research on canopy flora and fauna has increased, bringing awareness to the importance of "maintaining the diversity, resiliency, and functioning of the forests they inhabit" (Nadkarni, 1994, p. 70). Erwin (1982) concluded that the number of canopy species thriving in tropical forests is usually twice as large as the fauna inhabiting the forest floors. Nadkarni (1994) further demonstrated that, at a community level, the fauna and flora living in forest canopies create symbiotic relationships by 
establishing support, food, and shelter. Nadkarni also described the forest canopies as having a significant effect on the different layers of the forest, starting at the forest floor and going all the way to the canopy. The existent microclimates within the canopy are more extreme than those on the forest floor; including lower levels of humidity, intense sunlight, higher water stress, and stronger wind speeds (Nadkarni, 1994). Nadkarni describes a study that measured wind speeds on a cloud ridge in Costa Rica that were $11.3 \mathrm{~m}$ per second in the canopy, versus the forest floor, where the wind speeds were $4 \mathrm{~m}$ per second.

Epiphytic plant communities hold a keystone role for nutrient cycling in the forest canopy. Because they do not have access to forest floor nutrients and water, they must intercept nutrients held in the atmosphere, often during storms and foggy conditions (Clark, Nadkarni, \& Gholz, 1998; Nadkarni, 1994). Epiphytes are also considered a keystone resource because during lean times, they provide shelter and nutrients to other species within the forest canopy by producing fruit and leaves (Nadkarni, 1994). Nadkarni (1994) describes how the shelter bryophytes, lichen, and arboreal soils provide in the canopy create microhabitats for invertebrates needing moisture to prevent desiccation. In Northern California, these symbiotic relationships have been studied by a number of researchers, from the growth of fern mats on accumulated arboreal soil in oldgrowth coast redwood canopies, to the use of old-growth coast redwood stands by bats (Myotis yumanensis and Lasionycteris noctivagans), to the use of epiphytic fern mats by the wandering salamander (Aneides vagrans) (Enloe, Graham, \& Sillett, 2006; Sillett \& Van Pelt, 2007; Spickler et al., 2006; Zielinski \& Gellman, 1999). 
For these relationships to develop, however, a well-developed structural support is needed, including large lateral branches, fire hollows, and reiterations in the canopy. Sillett and McCune (1998) found that two of the Douglas fir canopy lichen associates, Lobaria oregana and Pseudocyphellaria rainierensis, were more abundant in old-growth forest than in younger stands. They proposed that thick long-lived branches provide support during the formation of these epiphytic mats where environmental conditions, such as sunlight exposure, are less than likely to change (Sillett \& McCune, 1998). In Southwestern Washington, Ishii, Ford, and Dinnie (2002) found that a 450-year-old Douglas fir produced up to 10,000 foliated epicormic shoots from primary or secondary branches. Within the same research area, Van Pelt and Nadkarni (2004) took a groundlevel approach to document the structural characteristics of a chronosequence of 50- to 950-year-old Douglas fir forests. The younger stands showed a uniform structural growth, with structural diversity absent, whereas the older stands had significantly higher structural complexities in the canopy layer.

Characteristics \& Associates: Sequoia sempervirens stands. The $S$. sempervirens is a monoecious plant species, having both male and female cones within the same tree (Sawyer et al., 2000c). Two to five seeds (female) are produced under the scales in 2 to $3 \mathrm{~cm}$ cones (Little, 1980; Stuart \& Sawyer, 2001). The male cones form pollen. Coast redwoods are also able to reproduce asexually. When the parent tree is in decline, it will regenerate by sprouting clones at its base (Douhovnikoff, Cheng, \& Dodd, 2004). 
The characteristics of coast redwood forests vary from the southern edge of its distribution to its northern range. The northern range is defined as the area from Southwestern Oregon down to Humboldt Bay in California. The central range begins south of Humboldt Bay and extends to the northern limits of San Francisco, and the southern range begins south of San Francisco and continues to the mountainous coastal range to Monterey County (Sawyer et al., 2000b). Annual moisture and soil characteristics are variable within regions and across different slopes. The Franciscan formation of metamorphosed rocks is the common parent material of the coast redwood belt, especially in the northern section (Sawyer et al., 2000b; Waring \& Major, 1964). The U. S. Department of Agriculture (1988) described the soils of the redwoods forest as deep and highly productive; however, spodosol soils are formed adjacent to old-growth coast redwood stands in the central region.

Northern range. In the northern region, deposits from sand and loose soil originate from marine and non-marine terraces (Sawyer et al., 2000b). Near Crescent City and Humboldt Bay, redwoods are found on alluvial flats and terraces with minimum water saturation. Winter and spring bring cool weather and high levels of precipitation, including some snow. In areas of Del Norte and Northern Humboldt Counties, the annual precipitation is around $250 \mathrm{~cm}$ (Sawyer et al., 2000b; Waring \& Major, 1964). The species associated with the northern region of the redwood forests are mainly conifers in the overstory layer. Douglas fir (Pseudotsuga menziesii) is an associate of redwoods from the southern to the northern part of the coast redwood belt, with its density increasing in the dryer eastern slopes (Johnston, 1994; Sawyer et al., 2000b). Other 
associates found in the northern part of the coast redwood belt are grand fir (Abies grandis), Port-Orford-cedar (Chamaecyparis lawsoniana), sitka spruce (Picea sitchensis), western hemlock (Tsuga heterophylla), western red cedar (Thuja plicata), tanoak (Notholithocarpus densiflorus), and red alder (Alnus rubra) (Mahony \& Stuart, 2000; Zinke, 1988). Zinke (1988) showed an increase in hardwoods such as the presence of madrone (Arbutus menziesii) and black oak (Quercus kelloggii) further inland. The west to east transition from redwood vegetation type to redwood-Douglas fir-hardwood corresponds with a decrease in precipitation of $76.2 \mathrm{~cm}$ (Zinke, 1988). Transects in Big Lagoon, California, from west to east, showed coast redwoods first appearing at $1.6 \mathrm{~km}$ inland from the ocean and dropping out at $16 \mathrm{~km}$ away from the coast (Zinke, 1988).

The tallest redwood trees are found in the northern region, specifically in productive alluvial flats terraces, with some reaching heights over $107 \mathrm{~m}$, and overall accounting for over $70 \%$ of live trees (Sillett et al., 2010). Species found in the understory layer are mainly in the Rosaceae and Ericaceae families, including huckleberries, and a number of ferns and herbaceous species (Zinke, 1988). Mahony and Stuart (2000) classified community type near Crescent City, California in the following order: coast redwood-Douglas fir/coast rhododendron (Sequoia sempervirensPseudotsuga menziesii/Rhododendron macrophyllum), coast redwood-western hemlock/huckleberry (Sequoia sempervirens-Tsuga heterophylla/Vaccinium ovatum), coast redwood/sword fern (Sequoia sempervirens/Polystichum munitum), coast redwoodwestern hemlock/sword fern (Sequoia sempervirens-Tsuga heterophylla/ Polystichum munitum), coast redwood-western hemlock/salmon berry (Sequoia sempervirens-Tsuga 
heterophylla/Rubus spectabilis), coast redwood-red alder/salmon berry (Sequoia sempervirens-Alnus rubra/Rubus spectabilis) (p. 55).

Central range. The central range of the redwood belt shows topographical characteristics that are more mountainous; these include steep slopes and narrow canyons (Sawyer et al., 2000b; Zinke, 1988). Sawyer et al. (2000b) describe the terrain in the central range as more mountainous, with King Peak measuring over $1230 \mathrm{~m}$ above sea level (asl). The soils in the central portion of the coast redwood belt are more variable; however, Franciscan bedrock is still the most common parent material (Sawyer et al., 2000b). In the Mount St. Helena range, soils are composed of lava flow or Franciscan rocks associated with igneous material lacking sand (Sawyer et al., 2000b). In the central range, the marine terraces including those supporting pygmy forest vegetation are most prevalent (Sawyer et al., 2000b; Zinke, 1988).

Within the central range are the ecological staircases that support pygmy forests. The soils supporting the pygmy forest are highly acidic and nutrient deficient soils called spodosol. The ecotone between pygmy and nutrient rich forests with less acidic, more fertile soils has been described as abrupt in terms of changes in vegetation, water saturation, and soils, with only a few species tolerating the harsh soil conditions (Aitken \& Libby, 1994; Northup, Dahlgren, \& McColl, 1998; Zinke, 1988). Nevertheless, solitary redwood trees have been found occupying these infertile soils (Jenny, 1973; Sawyer et al., 2000b; Westman \& Whittaker, 1975).

Annual precipitation in the central region is similar to that of the northern region of the coast redwood belt, $250 \mathrm{~cm}$, but with warmer summers and inland fog that lasts 
only through the morning (Sawyer et al., 2000b). Central range coast redwood associates, however, are distinct from those of the northern range. Zinke's (1988) research at Anchor Bay showed grand fir disappearing in the central portion of the redwood belt; he also documented a continuous presence of tanoak and madrone from west to east. Coast redwood tree distribution typically ends at around $12 \mathrm{~km}$ east from the ocean, with Douglas fir dominating the vegetation inland from that point (Zinke, 1988). According to Zinke, the coast redwood stand furthest to the east is $71.6 \mathrm{~km}$ from the coast, located close to Angwin, CA.

Research by Giusti (2004) in Montgomery woods, $48 \mathrm{~km}$ east of the coastal town of Mendocino, found a higher density of tanoaks, but redwoods showed a total dominance in a 5.46 ha area, with Douglas fir following close behind. Other species found in the central range include big-leaf maple (Acer macrophyllum), bay laurel (Umbellularia californica), red alder (Alnus rubra), sword fern (Polystichum munitum), redwood sorrel (Oxalis oregana), rhododendron (Rhododendron macrophyllum), huckleberry (Vaccinium ovatum), salal (Gaultheria shallon), and azalea (Rhododendron occidentele) (Giusti, 2004). Other research carried out in a range of environmental conditions and past anthropogenic disturbances showed associations of coast redwood/tanoak/huckleberry (Sequoia sempervirens/Notholithocarpus densiflorus/Vaccinium ovatum), as well as coast redwood-Douglas fir-California bay (Sequoia sempervirens-Pseudotsuga menziesii-Umbellularia californica); the sampled areas were in Marin County and San Mateo County. 
Southern range. The southern portion of the redwood range is ecologically distinct from the northern and central range (Sawyer et al., 2000b; Zinke, 1988). Although the coast redwood belt averages $16 \mathrm{~km}$ in width, it is more variable and coast redwoods are found closer to the ocean in the southern portion of the range (Zinke, 1988). Old-growth coast redwood stands are few in this area due to logging during the early 1900s. They are limited to canyons on slopes and alluvial flats (Baker et al., 2006). Baker et al. (2006) describe a maximum elevation range of $1154 \mathrm{~m}$ asl. The annual precipitation from west to east is highly variable due to tall mountains preventing the "penetration of maritime air masses and orographic effects" (Baker et al., 2006, p. 940). Annual precipitation can exceed $100 \mathrm{~cm}$ (Baker et al., 2006; Sawyer et al., 2000b).

Still, Zinke (1988) found that coast redwood trees were the main conifers in Santa Cruz County from $5 \mathrm{~km}$ to $19 \mathrm{~km}$ from the coast. Douglas fir, tanoak, and madrone were still present, but at much lower densities than in the central ranges. At $19 \mathrm{~km}$ from the coast, the coast redwood-dominated vegetation is broken up by chaparral, with coast live oak (Quercus agrifolia) and chamise (Adenostoma fasciculatum) present. At $32 \mathrm{~km}$, coast redwood reappears in small patches and after that, the vegetation changes to chaparral (Zinke, 1988). At the southern tip of the redwood belt, redwood stands are found just a few meters from the coast and on wet canyon bottoms (Zinke, 1988).

The vegetative associations in the southern region are coast redwood-tanoakcoulter pine (Sequoia sempervirens-Notholithocarpus densiflorus-Pinus coulteri) and coast redwood-tanoak-redwood sorrel (Sequoia sempervirens-Notholithocarpus densiflorus-Oxalis oregana) (Mahony \& Stuart, 2004). At the lower elevations, 
associations of coast redwood/bracken-chain fern (Sequoia sempervirens /Pteridium aquilinum-Woodwardia fibriata) and coast redwood/sword fern-trillium (Sequoia sempervirens/Polystichum munitum-Trillium ovatum) are found, whereas, in the wet, higher elevation, terraces the coast redwood-big-leaf maple/California polypody (Sequoia sempervirens-Acer macrophyllum/Polypodium californicum) associations are formed (Sawyer et al., 2000b). The redwood-tanoak/round fruited sedge-Douglas's iris (Sequoia sempervirens-Notholithocarpus densiflorus/Carex globosa-Iris douglasiana) association is formed on convex slopes above $243.8 \mathrm{~m}$ in elevation (Borchert, Segotta, \& Purser, 1988; Sawyer et al., 2000b). The frequency of hardwoods such as madrone, bay laurel, red alder, and big-leaf maple increases with distance from the coast (Zinke, 1988).

Canopy ecology of S. sempervirens. Redwood trees at a young age share similar growth characteristics of other conifers in that they have an orthotropic and monopodial main trunk, in other words, a straight vertical growth with branches originating from a single axis (Harris \& Harris, 2001; Sillett \& Van Pelt, 2007). Shigo (1998) defines monopodial as excurrent growth, which is the result of pronounced apical dominance, creating a growth form similar to that of a Christmas tree. In contrast, decurrent growth is in the form exhibited by trees with rounded crowns, such as oaks (Shigo, 1998). With age, coast redwood canopy structure losses its strong excurrent form, which may be the result of exposure to various extreme weather conditions or to genetics. They develop codominant trunks high in the canopy, which Shigo (2008) describes as the codominance as the growth between two shoots at the tip of the same stem. As these canopy structures 
increase in size and with age, they can provide shelter and support to flora and fauna within the canopy.

Giusti (2004) described that old-growth forest structure and composition is a result of random natural catastrophic disturbances, creating an ecosystem unique and difficult to replicate. Coast redwood trees are tolerant to such catastrophic events. Large snags, dead standing or downed trees, are ecologically important in old-growth forests (Hanson, 2010). Hanson (2010) describes snags as infrequent, endangered, and ecologically important in all forests types. In addition, redwoods have the ability to send out vertical sprouts from their roots after being buried during flood events, thus creating a multistoried root system (Johnston, 1994; Stone \& Vasey, 1968). Coast redwoods' ability to sprout is not limited to the root system. They can also sprout from the main trunk, branches, and limbs after injury from windstorms or to gain access to sunlight in nearby canopy gaps (Johnston, 1994; Sillett \& Van Pelt, 2000a, 2000b, 2007).

The structural complexity found in the canopy of an old-growth coast redwood allows for the symbiotic relationships described by Nadkarni (1994) to develop. These relationships include supporting plants established within the canopy, which intercept moisture that then drips to the forest floor. These structural features provide shelter to nesting or resident vertebrate and invertebrate species, and enhance nutrient cycling. Furthermore, the ability of the redwood to sprout vegetatively from the main trunk and lateral branches, forming large reiterations that develop over several hundred years, allows for microhabitats to develop within the canopy. Reiterations result from significant change to the crown structure, such as increased access to light from a tree 
fall, a trunk breaking during extreme weather conditions, or simply a small sprout growing over time (Sillett, 1999). Some microhabitats are formed by arboreal soils or created from leaf litter, redwood bark, dead roots, and live roots, allowing other vascular epiphytes to grow and provide vertebrates and invertebrates shelter, food, and water (Sawyer et al., 2000b).

The scale of structural complexity in the coast redwood canopy is higher than that found in other conifers, including Douglas fir. The large reiterations created by redwoods support significant amounts of biomass. The biomass of an epiphytic huckleberry (Vaccinium ovatum), for example, was recorded at $212 \mathrm{~kg}$, followed by a leather fern (Polypodium scouleri), measuring $196 \mathrm{~kg}$ (Sillett \& Van Pelt, 2007). In comparison, the canopy of an old-growth Sitka spruce supports the second greatest amount of biomass, up to $59 \mathrm{~kg}$ of epiphytic plants, and $131 \mathrm{~kg}$ of decomposing organic matter (Ellyson \& Sillett, 2003). Coast redwoods are able to support the biomass of epiphytic plants because of their branching structural characteristics, and epiphytic plants in turn create habitats for other species.

Within a 1-hectare plot, $60 \mathrm{~m}$ asl, in Prairie Creek Redwood State Park, Sillett and Van Pelt (2007) climbed 27 coast redwoods, collected data on epiphyte density, and monitored the canopy microclimates. They found 13 species usually rooted on the forest floor growing as vascular epiphytic plants in the crowns of the 14 largest trees within the plot. Most of the trees had over 100 reiterations between $35-85 \mathrm{~m}$ above ground in the canopy, with some of the trunks measuring over $260 \mathrm{~cm}$ in diameter (Sillett \& Van Pelt, 2007). The authors concluded that the presence of epiphytic plants assisted in the 
development of arboreal soils. They found the arboreal soils originate from the decomposition of dead roots, mainly from leather ferns. Further research was carried out within this 1-hectare plot of a single tree named Iluvatar.

The Iluvatar redwood tree reached a height of $91.5 \mathrm{~m}$, a total stemwood volume of $1,032.8 \mathrm{~m}^{3}$, and a diameter at breast height (DBH) of $6.1 \mathrm{~m}$ (Sillett \& Van Pelt, 2000b). Iluvatar has a total of 134 reiterated branches, with one reiteration described as "a trunk from a trunk from a trunk from a trunk from a trunk from a trunk from the main trunk" (Sillett \& Van Pelt, 2000b, p. 11). The reiteration is called Trunk 1, which supports 54 other trunks. It has a $2.6 \mathrm{~m}$ basal diameter coming out of the main trunk, and it is $23.7 \mathrm{~m}$ long. In addition, trunks on Trunk 1 have fused together, displaying an interconnected complexity where it is difficult to determine where one branch ends and another begins. The canopy flora consisted of five species of epiphytes. The dominant epiphytic plant was leather fern, followed by huckleberry. The plants were found on reiterations that supported thick layers of canopy humus (Sillett \& Van Pelt, 2000b).

Sillett and Van Pelt (2000a) used linear regressions to calculate relationships between canopy structures, such as basal diameter of reiterations, wood volume, total length, and height of branch origin. Linear regressions were also used to measure relationships between crown mapping and epiphytes (Sillett, 1999). Van Pelt and Sillett (2008) also used linear regression analysis to predict the development of the canopy structures of 70 individual Pseudotsuga menziesii. It was calculated that bark thickness was strongly and significantly correlated with diameter of branches $\geq 4 \mathrm{~cm}$, which allowed for the calculation of cambium surface. Linear regression identified a strong and 
significant correlation between foliar units (a unit used to quantify leaves, bark, cambium, and wood by counting clusters of stems and leaves) and branch size. This was done by using the measured basal diameter, length and leaf mass of a $>4 \mathrm{~cm}$ branch. Overall, the study concluded that tree size and canopy complexity was strongly correlated with tree age; and incremental growth potential was correlated with the measured diameter at breast height of the main trunk over a five-year period.

Sillett and Van Pelt (2000a) also mapped the canopy of the $16^{\text {th }}$ tallest redwood, the Redwood Creek Giant, in Redwood National Park. It is $109.8 \mathrm{~m}$ tall, had a base diameter of $5.6 \mathrm{~m}$, and its diameter at $65 \mathrm{~m}$ was over $3 \mathrm{~m}$. This tree had a total of 148 reiterations originating from the main trunk, other branches, and limbs. The canopy of the tree started at over $50 \mathrm{~m}$, and its crown diameter was over $25 \mathrm{~m}$ at a height of $100 \mathrm{~m}$. The Redwood Creek Giant also provided habitat to a diversity of epiphytes, including the tallest epiphytic tree ever recorded, a California Bay Laurel (Umbellularia californica), growing at $98.3 \mathrm{~m}$. Within the canopy, the deepest arboreal soil measured more than 50 cm (Sillett \& Van Pelt, 2000a).

Enloe et al. (2006) describe arboreal soils as soils made of decomposing organic material from decaying epiphytic plants and leaf litter, found in the canopy of old-growth forests. Their research, carried out at Prairie Creek Park and Jedediah Smith Park, found the physical composition of soil within the two trees studied generally consisted of redwood bark, loose litter, dead rhizome, unrecognizable decomposing plant material, and fine roots, and they recorded macrofauna, predominantly millipedes and centipedes. Nitrogen content was very consistent in all horizons for both trees; it did not change with 
depth. Calcium, magnesium, potassium, and sodium were also recorded for all horizons for both trees. Calcium concentration was higher in the Prairie Creek Park. Waterholding capacity increased with depth in soils that were in crotches, but soils on limbs were unable to hold water due to drainage. Enloe et al. (2006) concluded that as organic matter decomposes, it increases the soil ability to hold nutrients and water; in addition, for arboreal soils to form, the tree must be large, with stable lateral branches and crotches.

Fauna inhabiting old-growth S. sempervirens. A total of 202 amphibians, reptiles, birds, and mammals are known to occupy the redwood forests (Cooperrider et al., 2000). LaHaye and Gutiérrez (1999) concluded that for a forest to support life "the structure of the forest is as important as its age" (p. 329). Cooperrider et al. (2000) determined old-growth redwood forests provide shelter and food to 42 vertebrate species listed by the state of California and federal agencies as species of special concern, threatened, or endangered; and four invertebrate species were endangered or threatened. A number of old-growth coast redwood forest characteristics provide shelter and food for these species. Redwoods are home to anadromous salmonids, which provided food to non-aquatic animals, like black bears, grizzly bears (which are extinct from the region), wolverines (listed as endangered in California, with a small number of unconfirmed sightings), and bald eagles (Cooperrider et al., 2000).

The wandering salamander (Aneides vagrans) has been recently found to live in temperate old-growth coast redwood canopies, favoring the tunnels found under damp mats of epiphytic ferns (Spickler et al., 2006). It breathes through its skin, a process that 
requires constant moisture. Prior to Spickler et al.'s (2006) research, this species was described as a terrestrial salamander until the discovery of a clutch of eggs from a felled redwood. At tree-level, salamander abundance was correlated to the amount of water storage by ferns and size of fern mats in crotches; these areas have the highest moistureholding capacity in the canopy (Enloe et al., 2006; Spickler et al., 2006).

The marbled murrelet (Brachyramphus marmoratus) is listed as an endangered species (Cooperrider et al., 2000). It is a small, private seabird that travels inland to its nesting site from the ocean. The two remaining marbled murrelet populations in California are found in an old-growth coast redwood forests in Northern California, and in an old-growth coast redwood patch in the southern range in California (Baker et al., 2006). Baker et al. (2006) found nesting sites located around $9 \mathrm{~km}$ inland, on the lower half of the slope, and near streams. They hypothesized the nests sites were near streams, and streams are used as a flying corridor to and from the ocean. A total of 17 nests were found, with $41 \%$ on redwoods trees with an average $\mathrm{DBH}$ of $244 \mathrm{~cm}$ and the remaining nests were found on Douglas firs with an average DBH of $186 \mathrm{~cm}$ (Baker et al., 2006). The hypothesis underlying Douglas fir preference over redwood is the number of available limbs; Douglas fir trees had four times more limbs greater than $10 \mathrm{~cm}$ in diameter than redwood trees (Baker et al., 2006).

Zielinski and Gellman (1999) researched bat use of redwood trees with large fire cavities within small patches of remnant old-growth, as well as in contiguous forests of old-growth coast redwood trees. Bats favor trees with large cavities for roosting. They occupy these cavities year round. Zielinski and Gellman's results showed guano data 
suggesting that bats use old-growth patches more than contiguous forests. However, it was concluded that the guano data could have been from multiple bats, or an individual traveling from patch to patch of old-growth stands (Zielinski \& Gellman, 1999). Mazurek and Zielinski (as cited in U. S. Department of Agriculture, 2003) recorded other species using large cavities in an old-growth coast redwood stand in Mendocino, California. Pygmy nuthatches (Sitta pygmaea) were observed bringing food into the cavity followed by vocalization of younglings. Barn owl (Tyto alba) droppings and food pellets were observed, as well as nesting violet-green swallows (Tachycineta thalassina) (U. S. Department of Agriculture, 2003).

The spotted owl (Strix occidentalis caurina) is a federally endangered species depending on old-growth forests (Murphy \& Noon, 1992; Sawyer et al., 2000b). The northwestern portion of California is the southern limit of spotted owl habitat (LaHaye \& Gutiérrez, 1999; Murphy \& Noon, 1992). In the Klamath Mountains and along the coast ranges from the Southwestern Oregon border to Marin County, LaHaye and Gutiérrez (1999) discovered $83 \%$ of the nests were found on Douglas fir and $9 \%$ on coast redwoods, as well as a small percentage in other conifer and hardwood species. The nesting forest types are described as mixed conifer forest and redwood forest, with a preference in complex canopy structures created by large-diameter trees, and an understory layer of mature hardwoods (LaHaye \& Gutiérrez, 1999).

Invertebrates assist in imperative ecological processes in old-growth redwood forests, such as nutrient cycling, decomposition processes, disturbance and successional processes, and the successful reproduction and growth of fungi, plants, and vertebrates 
(Cooperrider et al., 2000). In an undisturbed forest in Oregon, invertebrates accounted for $85 \%$ of all species including vertebrates and vascular plants (Cooperrider et al., 2000). In this forest, Cooperrider et al. (2000) found that one square-meter of undisturbed soil was occupied by 200 to 250 species of invertebrates.

\section{Pygmy Primary Forests}

Endemic species and ecotypes adapted to, or became tolerant of, spodosols in Mendocino County, California, form the pygmy forest. These plant species include bolander pine (Pinus contorta spp. Bolanderi), pygmy cypress (Cupressus pygmaea), bishop pine (Pinus muricata) and a number of Ericaceous shrubs. These include glossy leaf manzanita (Arctostaphylos nummularia), redwood manzanita (Arctostaphylos columbiana), coast rhododendron (Rhododendron macrophyllum), western labrador tea (Rhododendron columbianum), and salal (Gaultheria shallon) (Jenny, 1973; Northup et al., 1995; Westman, 1975; Westman \& Whittaker, 1975). Jenny (1973) originally observed these species dominating the pygmy forest landscape; however, on rare occasions, he found a stunted "yellow-leafed struggling redwood tree" tolerating the nutrient deficient soils (p. 13). Westman and Whittaker (1975) studied the productivity of species, including the coast redwood, inhabiting pygmy forests and adjacent communities in five different areas in Northern California. They found edaphic conditions contributed to the physiognomy of the plant species within the terraces, since the pygmy cypress could reach heights well over $50 \mathrm{~m}$ in height in productive soils, and the vegetative changes from fertile soils to acidic soils were abrupt. Northup et al. (1998) 
found that the abrupt change occurs less than $10 \mathrm{~m}$ from the margins of the pygmy forests.

The pygmy forest is found on five coastal terraces in Mendocino County, California, that are a result of tectonic movements, wave activity, and fluctuation in sea level during the Pleistocene period (Aitken \& Libby, 1994). Wave action over time created the terraces, which at the same time were being pushed up by the fault block between the Navarro River and the Ten Mile River (Russell \& Woolhouse, 2012). The first terrace, closest to the ocean, is dominated by grassland with rich prairie soils, known as mollisols (Jenny, 1973); dating back approximately 150,000 years. The second terrace is approximately 285,000 years old, and it is host to the coast redwood (Aitken \& Libby, 1994; Jenny, 1973). In this terrace, podzolization is more apparent. The soil lacks an A horizon, which is the zone where organic matter is being decomposed and leached down to the subsequent horizons (Jenny, 1973; Johnston, 1994; Russell \& Woolhouse, 2012). The lower horizon, called the B horizon, is described by Russell and Woolhouse (2012) as an iron-stained, nutrient deficient, clay layer, containing low levels of organic matter. The third, fourth, and fifth terraces, where the extreme pygmy soils are found, have highly acidic soils, with a pH as low as 2.9 (Aitken \& Libby, 1994). The soil nutrients in these terraces have been completely leached. The fifth terrace is approximately 1 million years old (Aitken \& Libby, 1994; Westman \& Whittaker, 1975). If the Clements theory of succession were accepted, the fifth terrace would be the final succession in the pygmy forest ecosystem, with bishop pine being the climax species (Jenny, 1973; Northup et al., 
1995). Jenny (1973) describes the bishop pine as a species that is conservative in its nutrient uptake compared to the coast redwood and the Douglas fir.

The ash-grey podzol soil found below the organic layer is the result of extreme nutrient leaching. Podzol is formed by soil nutrients traveling down the soil column along with fine clay particles (Fox, 1976; Jenny, 1973). This weathering process continues through centuries, resulting in the development of a hardpan layer, usually found $30 \mathrm{~cm}$ below the surface, which limits root growth to the organic and ash-grey soil layers (Johnston, 1994; Russell \& Woolhouse, 2012). In Mendocino, the hardpan is formed during the formation of the second terrace. It is the product of organic matter from the conifers occupying this terrace, sand deposition from wind, soil erosion washed down from higher terraces, and nutrient leaching from the winter rains. Jenny (1973) describes the hardpan formation as the result of iron being released in the form of iron hydroxide cementing the negative quartz grains (p. 17) and resulting in the rust oxidizedcolored hardpan. This process occurred in each terrace, moving up like an escalator (Figure 1) (Fox, 1976), such that all five terraces have the "same mineralogical composition" (Jenny, 1973, p. 8) but large age difference.

Furthermore, the clay hardpan is extremely impermeable; thus, during the winter rains, prolonged flooding occurs, and water drains slowly to the lower terraces, which results in nutrient leaching (Aitken \& Libby, 1994). Nutrient concentrations in pooled water from rain runoff are lower than in water from rainfall $(\mathrm{Yu}$, Dahlgren, \& Northup, 1999). Also, the hardpan restricts plants' fibrous roots to the organic layer. Yu et al. (1999) measured most of the roots in the organic layer within the second terrace, whereas 
in the older terraces the roots were restricted to $60 \mathrm{~cm}$, which included the organic layer. Due to the significant amount of leaching, the only available nutrients are within the organic layer.

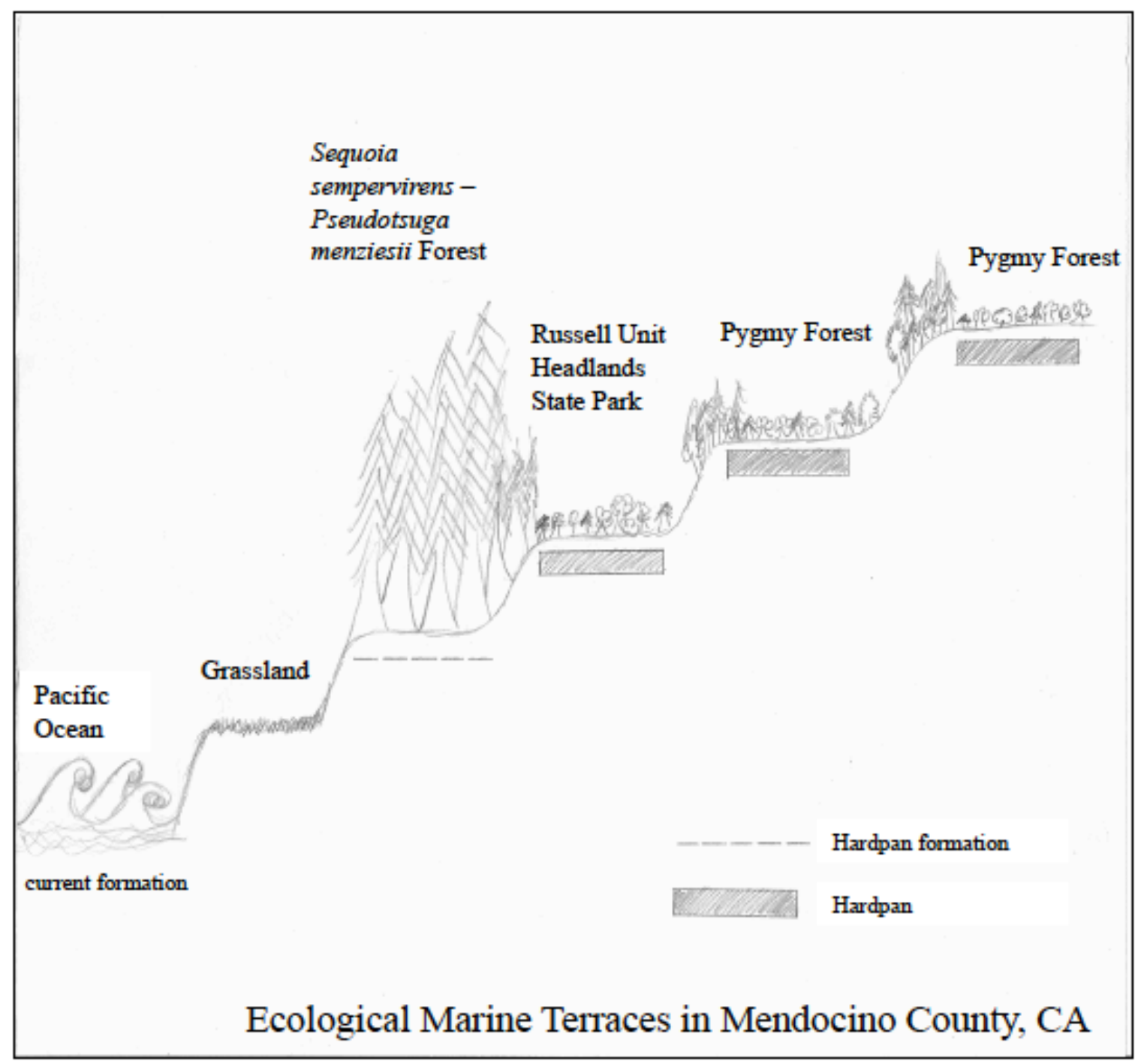

Figure 1. Ecological staircase in Mendocino County from west to east.

In Figure 1, each terrace shares the same mineralogical composition, but a different geological age. The Russell Unit Headlands State Park is a primary pygmy forest adjacent to the towering coast redwood-Douglas fir community. 


\section{Soil Nutrients}

Yu et al. (1999) found organic matter influenced available nutrients and plant growth within the pygmy forest. A well-drained mineral soil has between $1 \%$ and $6 \%$ organic matter in the topsoil and less in the subsoil (Brady, 1990, p. 12). Organic matter shelters absorbing roots from the acidic soils and releases polyphenols, such as tannins, into the soil that aid in the conservation of nutrients by enhancing edaphic conditions (Northup et al., 1998; Yu et al., 1999). Polyphenols are mostly stored in the leaves. Some species in the Ericaceae family are known to produce polyphenols, and some of these species have a high frequency within the pygmy forest (Yu et al., 1999). Yu et al. (1999) further describe polyphenols to be positively correlated with cation exchange capacity, which is also correlated with organic matter.

Hydrogen ions $(\mathrm{H})$ in the soil influence the availability of other nutrients to plants. It is an element found in carbohydrates and other compounds essential for plant growth (Soil Improvement Committee, California Fertilizer Association [SICCFA], 1980). It is a component of water. In soils, hydrogen bonding is responsible for adsorption and cohesion of water. The former process keeps water molecules attached to soil surfaces, whereas cohesion is responsible for the attraction of water molecules to each other (Brady, 1990). The two processes facilitate water movement through and retention in the soil particles. However, the amount of hydrogen alters the soil acidity, since acidity is determined by the amount of $\mathrm{H}$ ions in the soil $(\mathrm{pH})$. Brady (1990) calls the amount of Hydrogen ions in the soil "active acidity" (p. 218). 
Cation exchange capacity (CEC) is the measurement of the number of negatively charged sites on the soil particle micelles that determine the soil's ability to adsorb positive charged ions, cations $\left(\mathrm{K}^{+}, \mathrm{Na}^{+}, \mathrm{Ca}^{2+}, \mathrm{Mg}^{2+}, \mathrm{H}^{+}\right)$(Gliessman, 2007). $\mathrm{CEC}$ is measured in milliequivalents of cations per $100 \mathrm{~g}$ of dry soil. An equivalent is the measurement of a substance that can react with or replace one mole of $\mathrm{H}^{+}$. Since the amount of substance in an equivalent is often so small, milliequivalents is the preferred nomenclature. One centimole of charge per kilogram of soil equals 1 milliequivalent per 100 grams of soil (Brady, 1990). The ability of the soil particles to hold on to cations determines the availability of nutrients to the plant roots. If the CEC is small, then nutrients will be leached before the plant absorbs them. According to Brady's (1990, p. 203) table 7.7 on CEC of surface soils from different areas of the United States (1990), the soil orders with a CEC of $2-3 \mathrm{cmol} / \mathrm{kg}$ are sandy. Soil orders with an exchange capacity between 3 and $10 \mathrm{cmol} / \mathrm{kg}$ are characterized as sandy loam. The loam soil order has an exchange capacity between 11 and $16 \mathrm{cmol} / \mathrm{kg}$, and silt loam from $13-26 \mathrm{cmol} / \mathrm{kg}$. However, clay and clay loam have a low exchange capacity of Udult clay order from 4-5 $\mathrm{cmol} / \mathrm{kg}$ and a higher CEC in the Xeroll and Udalf orders. Also, hydrogen displaces nutrient cations, which causes nutrient leaching. The potential of hydrogen, $\mathrm{pH}$, is a measure of the amount of hydrogen ions in the soil. Decomposition of organic matter will also increase the number of hydrogen ions.

The percentage of water-holding capacity is a ratio of the water volume in the soil to the total volume of soil, and it is related to the total porosity of the soil. Soil porosity in compacted soils is low, thus negatively affecting water-holding capacity and 
permeability. Water has a higher likelihood of flowing out of saturated soils, than from soils with less moisture (Brady, 1990). From the soil orders, clay holds the most water content, followed by loam then sand. Brady (1990) describes clay particles as being glued to the water molecules; this inhibits the plant's ability to absorb more than half the molecules. Soil structure significantly influences water-holding capacity, such as porosity or compacted soils. Limiting the former can result in poor water-holding capacity, whereas the latter can act like clay particles and tightly hold on to the water molecules.

Sulfur is classified as a macronutrient. Plants absorb it through their roots in the form of sulfate ions, or through leaves in the form of gas in industrialized areas (Brady, 1990; SICCFA, 1980). It is a soluble compound that can be leached out rapidly from the soil. The adsorption rate of sulfur is dependent on abiotic factors, such as soil $\mathrm{pH}$, waterholding capacity, temperature, and porosity (Brady, 1990). Sulfur is necessary in the production of proteins and chlorophyll, uptake of phosphorus, and plant metabolism (Brady, 1990; Tucker, 1999). Sulfur deficiency in plants causes stunted growth and delayed maturity, small and thin weak plants, and yellowing of the leaves (SICCFA, 1980; Tucker, 1999). Nitrogen and sulfur deficiency symptoms may be distinguished in that yellowing of the leaves associated with sulfur deficiency and starts with younger leaves, whereas in nitrogen deficiency it begins in older leaves.

More than half the Phosphorus (P) plant needs comes from organic matter. Ideal levels of $\mathrm{P}$ are between 20 and $30 \mathrm{ppm}$. However, the amount of $\mathrm{P}$ available to plants is $0.01 \%$ of the total $\mathrm{P}$ in the soil (Brady, 1990, p. 353). The plant absorption of $\mathrm{P}$ is 
dependent on the soil $\mathrm{pH}$, and it can only be taken up as phosphates, $\mathrm{H}_{2} \mathrm{PO}_{4}, \mathrm{HPO}_{4}$, and $\mathrm{PO}_{4}$. However, in acidic soils, if $\mathrm{P}$ binds to iron and aluminum, it results in the formation of insoluble phosphates, such as $\mathrm{Al}(\mathrm{OH})_{2} \mathrm{H}_{2} \mathrm{PO}_{4}$ (Brady, 1990, p. 358; SICCFA, 1980). Consequently, aluminum greatly reduces the amount of $\mathrm{P}$ available to plants. Availability of $\mathrm{P}$ is at its maximum in soils with a $\mathrm{pH}$ between 6.5 and 7.0 (SICCFA, 1980). P is an essential element in plant growth, thus it is considered a primary nutrient (Tucker, 1999). It is involved in the breakdown of carbohydrates during photosynthesis, essential in numerous metabolic processes including nitrogen fixation, and is an important component in deoxyribonucleic acid (DNA) (Brady, 1990; SICCFA, 1980). In addition, $\mathrm{P}$ is a constituent of two compounds, adenosine diphosphate (ADP) and adenosine triphosphate (ATP), which are necessary to supply energy for chemical reactions. $\mathrm{P}$ is involved in nutrient transport and molecule formation, processes that require the use of large amounts of energy (Brady, 1990). It is also an element in phospholipids, which is used by cell membranes to regulate the movement in and out of the cell and organelles (Gliessman, 2007). Physical characteristics of P deficiencies include stunted growth, dark green foliage with dying ends, and delayed maturity (SICCFA, 1980).

Another primary nutrient is Potassium $(\mathrm{K})$, found in most soil types except sand (Brady, 1990). Between 90\% and 98\% is in unavailable forms to plants (SICCFA, 1980). Gliessman (2007) states K's function is more regulatory. K is involved in regulating the opening and closing of stomates, responsible for activating enzymes used in the breakdown of sugars, starch production, and metabolic processes (Brady, 1990). In 
addition, it facilitates the transportation of sugars and starches throughout the plant, making it a mobile element within the plant (Gliessman, 2007; SICCFA, 1980). K is dependent on $\mathrm{pH}$ levels. An increase in lime results in an increase in CEC, which causes a raise in $\mathrm{K}$ adsorption by soil particles. So as $\mathrm{CEC}$ increases, available $\mathrm{K}$ decreases (Brady, 1990). Also, high levels of Ca can negatively affect $\mathrm{K}$ absorption by the plant. Physical characteristics of K deficiency are retarded growth, desiccation of the tip of the leaves (from more mature to younger), and leaning in plants (a weak trunk) (SICCFA, 1980).

Magnesium $(\mathrm{Mg})$ is considered a secondary plant macronutrient because of its large buildup in the plants' tissues. It is an ingredient in chlorophyll, a molecule responsible for light absorption during photosynthesis (SICCFA, 1980; Tucker, 1999). Like $\mathrm{K}, \mathrm{Mg}$ is mobile within the plant during periods of $\mathrm{Mg}$ deficiency. It is also involved in the movement of carbohydrates throughout the plant. It activates functions in the production of DNA and Ribonucleic acid, RNA (Tucker, 1999). Brady (1990) points to leaching as one of the major causes of $\mathrm{Mg}$ deficiencies in humid regions. Sandy soils are also deficient in Mg. Symptoms of Mg deficiency are yellowing of older leaves; if the lack of the nutrient persists, the leaves will turn red with dead spots (Tucker, 1999). Low $\mathrm{pH}$ level in the soil is also a contributing factor in $\mathrm{Mg}$ deficiency.

Calcium $(\mathrm{Ca})$ is a secondary plant macronutrient. It is a stagnant element found in the cell wall, and responsible for the formation of new cells. It neutralizes toxic acids during the growing period, and absorbs nitrogen (Tucker, 1999). Deficiencies include die 
back of the meristem regions, including the roots, and a weak trunk. Tucker (1999) describes the plant structure as "short and stubby" during Ca deficiency periods.

Sodium $(\mathrm{Na})$ in soils is found in neutral soluble salts $(\mathrm{NaCl})$ and in insoluble yet exchangeable forms. Saline soils are high in neutral salt, $\mathrm{NaCl}$ or $\mathrm{Na}_{2} \mathrm{SO}_{4}$. Soils that pool $\mathrm{Na}$ with weak negatively charged ions $\left(\mathrm{HCO}_{3}{ }^{-}\right.$and $\left.\mathrm{OH}^{-}\right)$are called alkaline soils (Gliessman, 2007). Large amounts of salts can have a significant negative effect on plant growth due to the affects of salts on nutrient and oxygen availability (Brady, 1990). 


\section{PROBLEM STATEMENT}

Stunted coast redwood trees have been observed within the pygmy soil formation (Jenny, 1973; Russell \& Woolhouse, 2012; Sawyer et al., 2000b; Westman \& Whittaker, 1975). Though characterization of Sequoia sempervirens canopy has been researched thoroughly in highly productive stands, it has not been studied in proximity of the pygmy forest where soils are unproductive and the growth form of coast redwood is stunted. This comparative study of coast redwood growth form and canopy structure, from extreme pygmy forests through the ecotone with primary redwood forest, provides important information about the species's adaptation and reaction to extreme soil conditions and its underlying variability in its ability to support epiphytic plants and to shelter canopy dwelling fauna.

\section{Objective}

The objective of this research was to characterize the growth form and canopy structure of Sequoia sempervirens across an old-growth redwood/pygmy forest ecotone and add to the growing literature on variability within old-growth forests.

\section{Study Question}

How does the growth form and canopy structure of S. sempervirens differ across an old-growth redwood/pygmy forest ecotone?

\section{Research Questions}

\section{Q1: Stand characteristics.}

Question 1a. Is there a correlation between Sequoia sempervirens height and soil properties, such as important plant nutrients (calcium $\left[\mathrm{Ca}^{++}\right]$, magnesium $\left[\mathrm{Mg}^{++}\right]$, 
potassium $\left[\mathrm{K}^{+}\right]$, sodium $\left[\mathrm{Na}^{+}\right]$, Phosphorus $[\mathrm{P}]$, Sulfate-Sulfur $\left[\mathrm{SO}_{4}-\mathrm{S}\right]$ and hydrogen $\left.\left[\mathrm{H}^{+}\right]\right)$, Cation Exchange Capacity (CEC), soil water-holding capacity, and $\mathrm{pH}$ ?

Question $1 \mathrm{~b}$. Is there a correlation between $S$. sempervirens diameter at breast height and soil properties?

Question 1c. Is there a correlation between the number of trees per plot and soil properties?

Question 1d. Are fire hollows correlated with tree structures (BDH and height) and soil properties?

\section{Q2: Canopy characteristics.}

Question $2 a$. Is there a correlation between canopy complexity (hierarchical canopy structures), tree height, DBH, and soil properties?

Question $\mathbf{2 b}$. Is there a correlation between the quantity of epiphytic vascular plants and structural characteristics, such as canopy complexity (hierarchical canopy structures), tree height, DBH, and fire hollows? 


\section{METHOD}

\section{Study Site}

This study was conducted on the Russell Unit of the Mendocino Headlands State Park approximately $1 \mathrm{~km}$ east of the Pacific Ocean in northern California, near the coastal town of Mendocino, $200 \mathrm{~km}$ north of San Francisco, California (Figure 2). The area's average annual precipitation is approximately $99 \mathrm{~cm}$, with an average temperature of $12.5^{\circ} \mathrm{C}$ (Northup et al., 1995). Westman and Whittaker (1975) describe the area as having a Mediterranean climate with wet winters, summer droughts, and fog during the spring and summer (p. 493). The property is currently managed by the state of California, under the Department of Parks and Recreation (Figure 3). The study site is the pygmy forest located in the southeast section of the property. 


\section{Primary Pygmy Forest, Russell Unit}

Mendocino Headlands State Park, Mendocino, CA

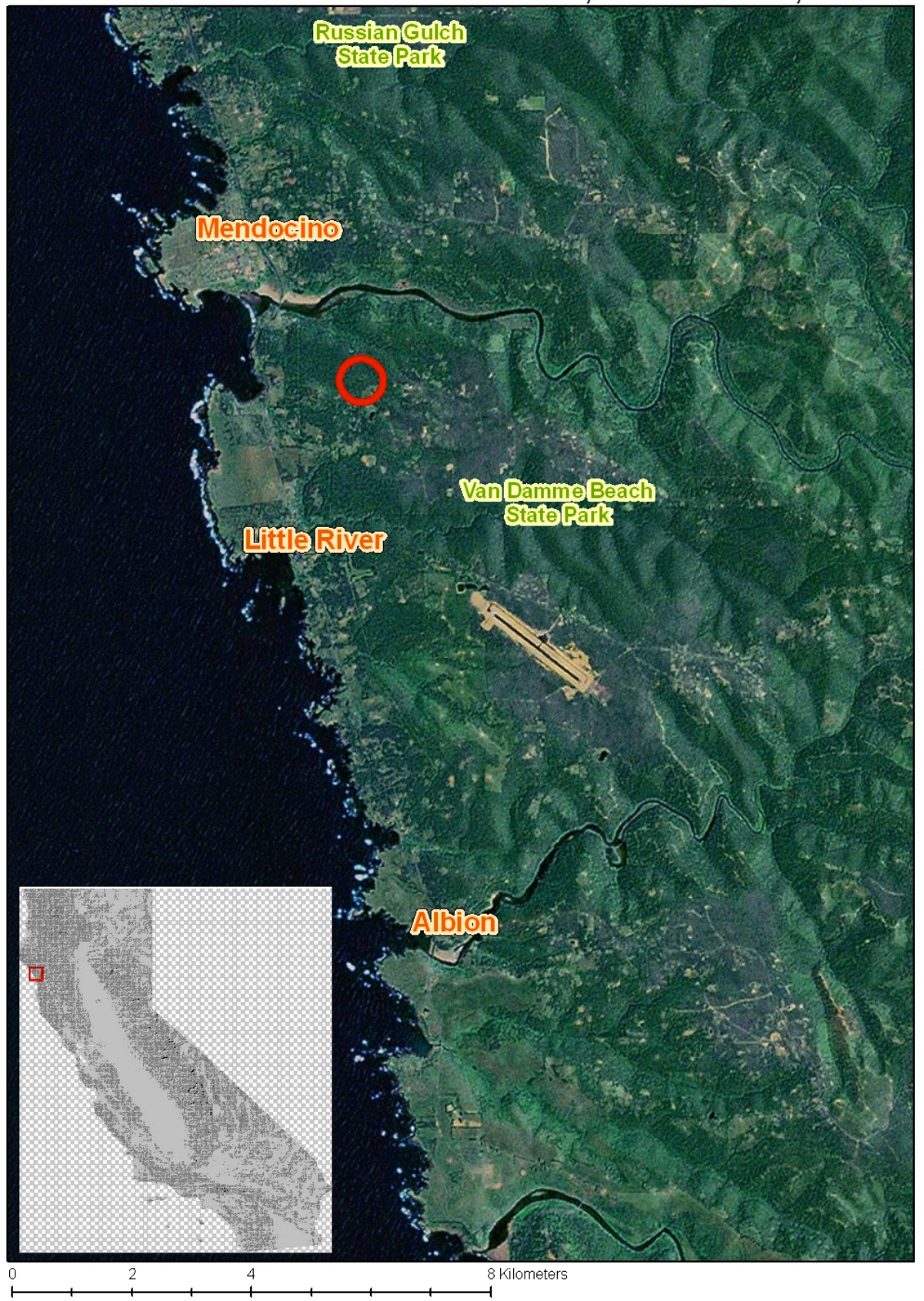

Map Developed by Elizabeth Lanham

Aerial imagery courtesy ESRI ArcGIS Online and data partners, including imagery from agencies supplied via the Content Sharing Program

Figure 2. Overview map of Mendocino County, California.

The red circle represents the Russell Unit of the Mendocino Headlands State Park. 
Russell Unit of the Mendocino Headlands State Park Estimated Old-Growth Distribution

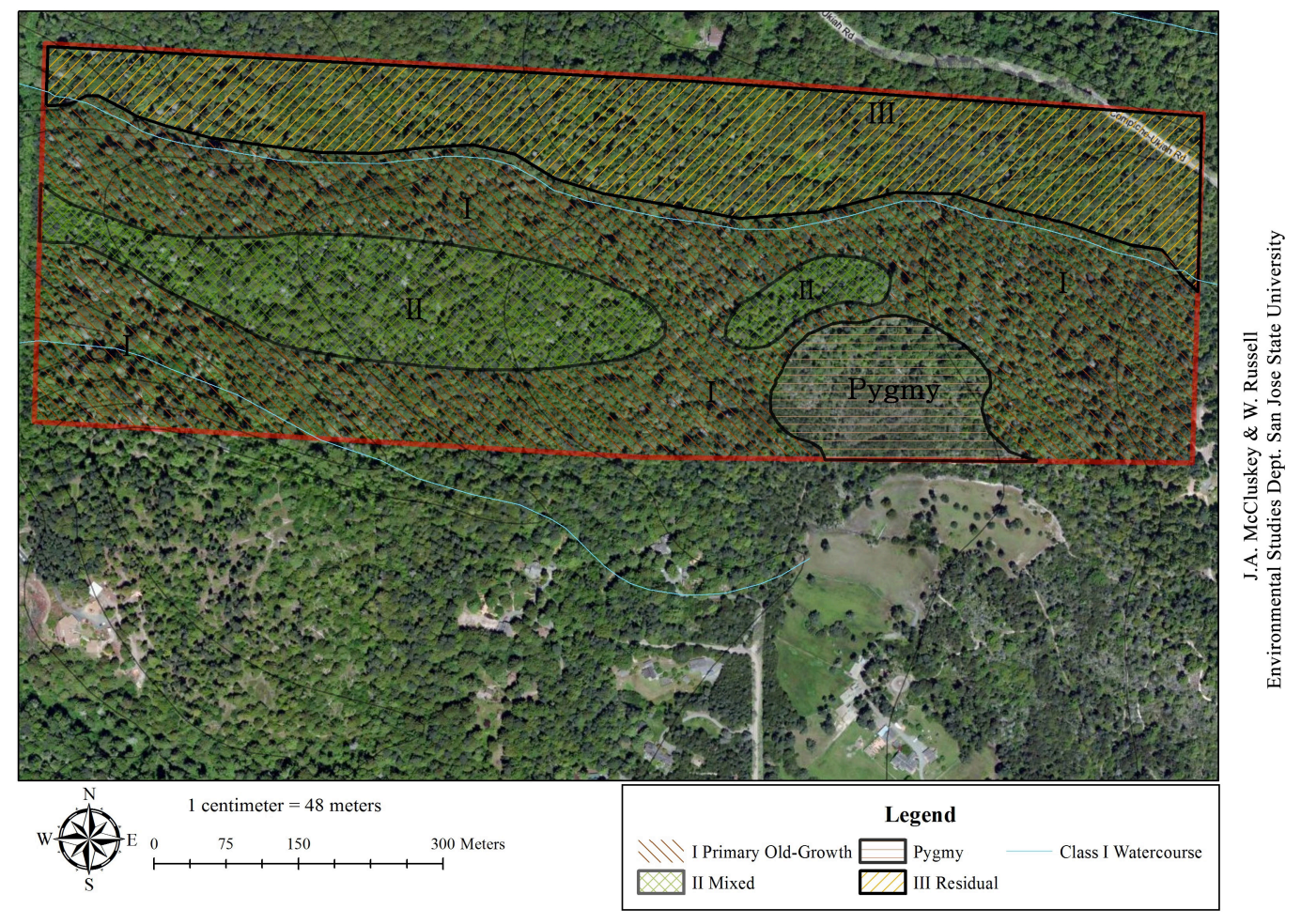

Figure 3. Map of the forest age classes and pygmy forest in the Russell Unit of the Mendocino Headlands State Park.

The ecotone of the pygmy forest in which the study was carried out, includes a stand of stunted old-growth S. sempervirens trees. Russell and Woolhouse (2012) characterized the growth of $S$. sempervirens at the study site, across the ecotone of the pygmy forests. Starting in the extreme pygmy vegetation and moving away toward the pygmy redwoods, categorizing them as shrub-like, young-looking with a single central leader, or full old-growth canopy development. Russell and Woolhouse found that change in height was associated with soil $\mathrm{pH}$ levels, and that increased distance from extreme pygmy soils had a positive effect on canopy height in S. sempervirens. They did 
not look at the canopy composition of the stunted old-growth $S$. sempervirens on the ecotone of the pygmy forest.

In the early 1900s, about one-third of the Russell Unit (Figure 3) was selectively logged. The Russell family purchased the property in the 1940s after which point logging ceased. After the death of Louis Russell in 1972, his wife, Ieda "Skilly" Russell, sold the property to the Trust for Public Lands at a small fraction of the property's worth so it would be protected from future logging and development. The property was then transferred to the California State Parks. Louis Russell was a man who steadfastly fought to protect in perpetuity the uniqueness of the site from loggers and developers. He died of a heart attack shortly after he testified against a proposed Timber Harvest Plan adjacent to the Russell Property at the Mendocino County Courthouse. Due to Louis Russell's heart condition, his doctor had strongly recommended against giving the speech (Dr. William Russell, personal communication, April 29, 2011).

\section{Study Design}

This study was a continuation of Russell and Woolhouse's (2012) study on the characterization of a pygmy forest in the Russell Unit Headlands State Park. The study site was broken down into five different strata by vegetation (Figure 4) and tree height (Figure 5) by Russell and Woolhouse, a method adapted from Westman and Whittaker (1975). In Figure 5, the size of the circle represents the height of the canopy. Each circle is a plot. Russell and Woolhouse identified and gave a description of each stratum in the following order: "Extreme pygmy" - the area where the shortest and most stunted vegetation is found. "Short pygmy" - the area with stunted vegetation, but with a gradual 
change in species composition and height. "Tall pygmy" - the area dominated by tall Ericaceae shrubs and large Bolander pine (Pinus contorta spp. contorta) and pygmy cypress (Cupressus goveniana ssp. pygmaea). "Transitional" - area where redwoods first begin to appear with codominant bolander pine and pygmy cypress. "Pygmy redwoods" - the area with stunted old-growth redwoods. This project used the above vegetation and canopy height characterization when selecting sample trees. 


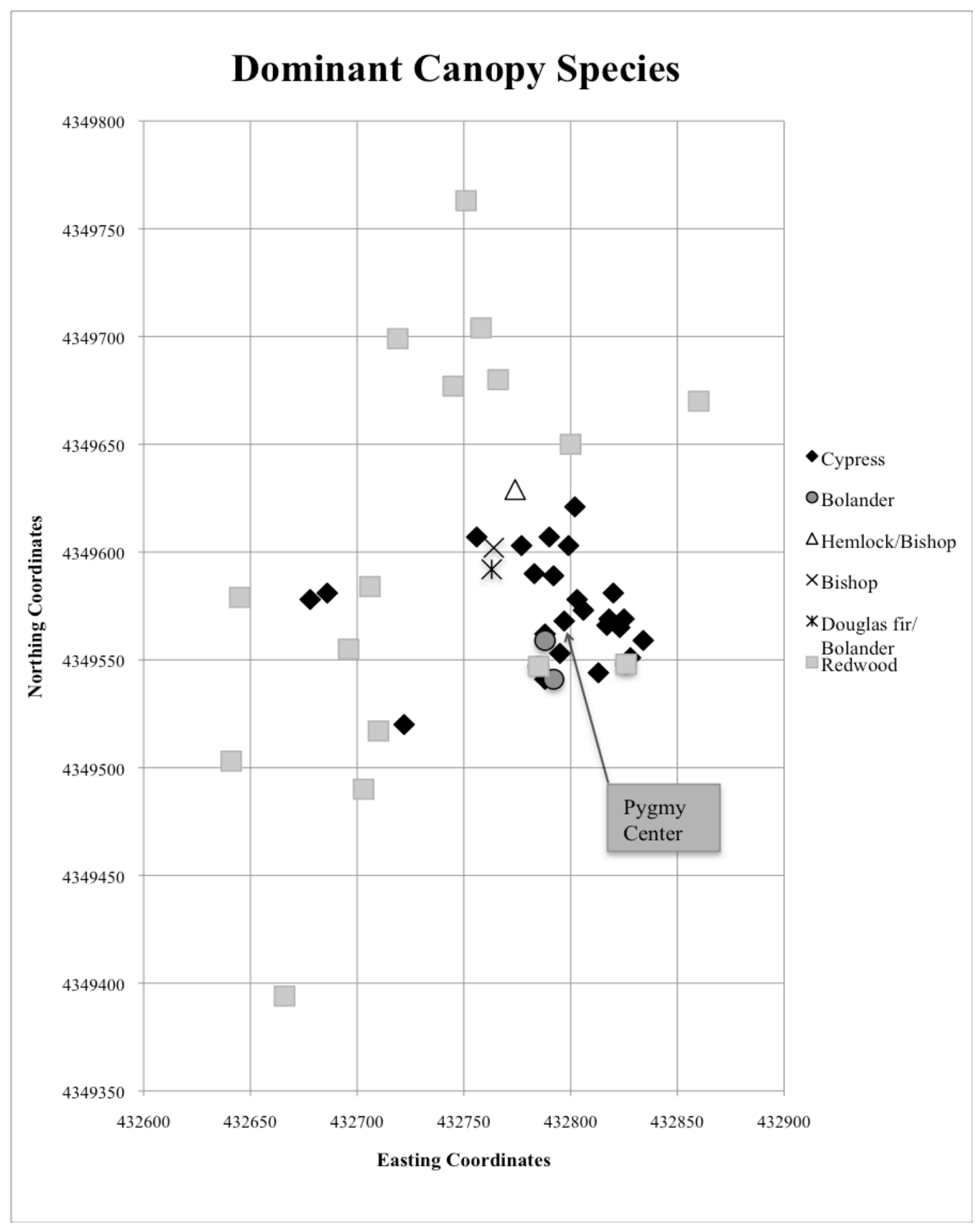

Figure 4. Dominant canopy species within the Russell Unit.

Cypress - Cupressus goveniana ssp. pygmaea. Bolander - Pinus contorta spp. contorta. Hemlock - Tsuga heterophylla. Bishop - Pinus muricata. Douglas fir - Pseudotsuga menziesii. Redwood - Sequoia sempervirens. Information gathered from Russell and Woolhouse data (2012). 


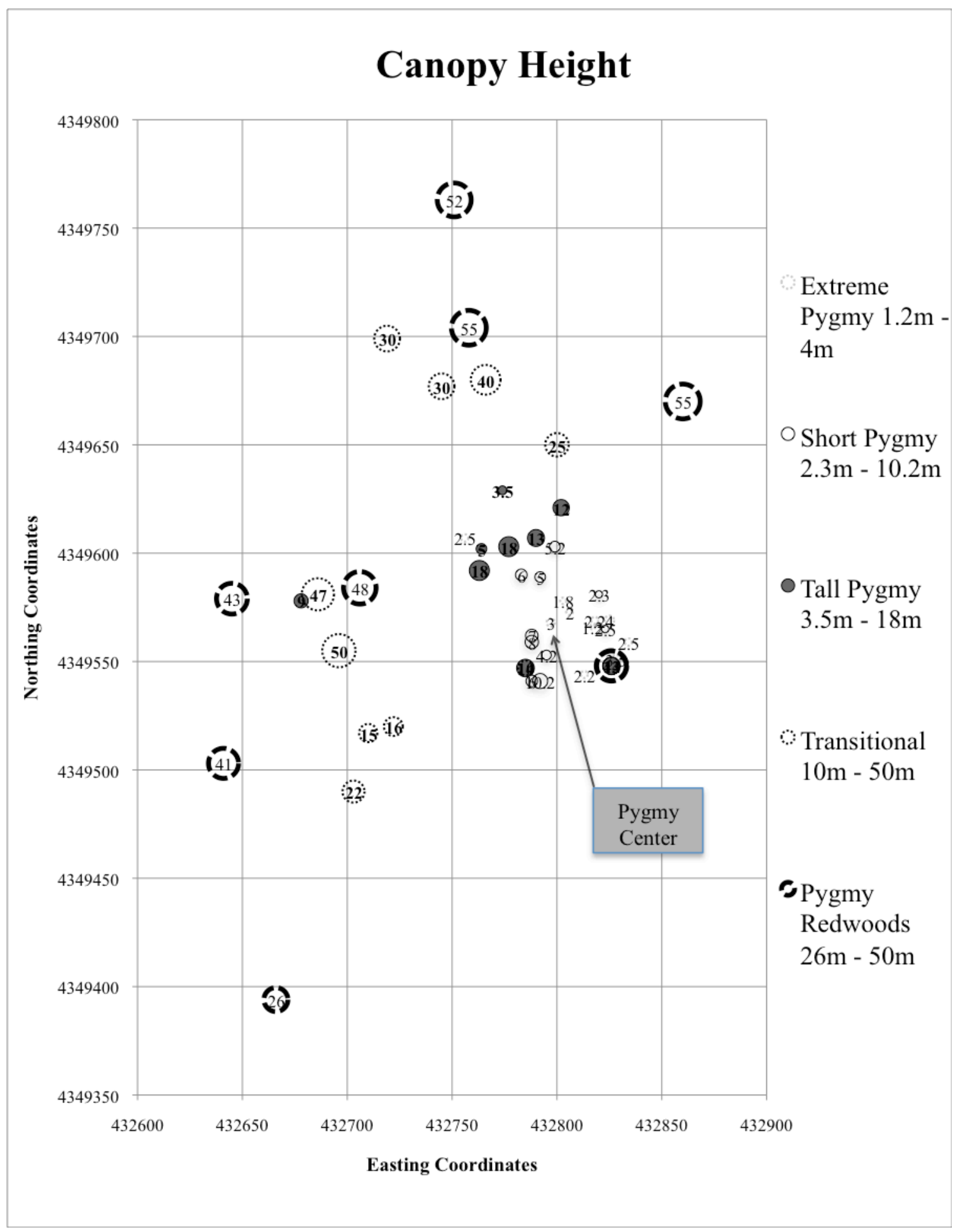

Figure 5. Canopy height within the Russell Unit.

Information gathered from Russell and Woolhouse data (2012). 
Plots were mapped using the universal transverse mercator (UTM) coordinates. Each plot was measured for maximum tree height and DBH, soil properties, and number of trees per plot. Coordinates from the canopy height and the dominant canopy species from Russell and Woolhouse (2012) data were mapped as a reference to choose the sample plots (Figures 4 and 5). Canopy characteristics were also evaluated within the same plots used for stand characteristics. The branch hierarchy method developed by Van Pelt and Sillett (2008) was used to quantify canopy complexity by looking at the number of combinations of hierarchy appendages. The method created by Van Pelt and Sillett gave a name and hierarchy level to each crown structure (i.e. trunk, limb, reiteration, and branch). Each combination of hierarchical appendages ended on a branch, the lowest in the hierarchy. The number of appendages for each combination represented a hierarchical rank. A limb was an appendage larger than a branch, whereas a reiteration was an appendage growing vertically, creating a new trunk. Last, the trunk was the origin of all hierarchical ranks.

A fire hollow was defined as a hollow where the internal height was greater than the height of the external opening (U. S. Department of Agriculture, 2003), and showing significant woodwound on the tree's fire scar (Figure 6). Shigo (1998) describes woodwound as the result of callus as nonrigid, uniform cells, lacking structure and function. Callus cells develop immediately around an injury and are produced by the cambium layer. As production increases, a callus becomes a woundwood. The cells become differentiated, rigid, and have different functions, which begin to "roll" over the injury, thus permanently covering the injured wood. 


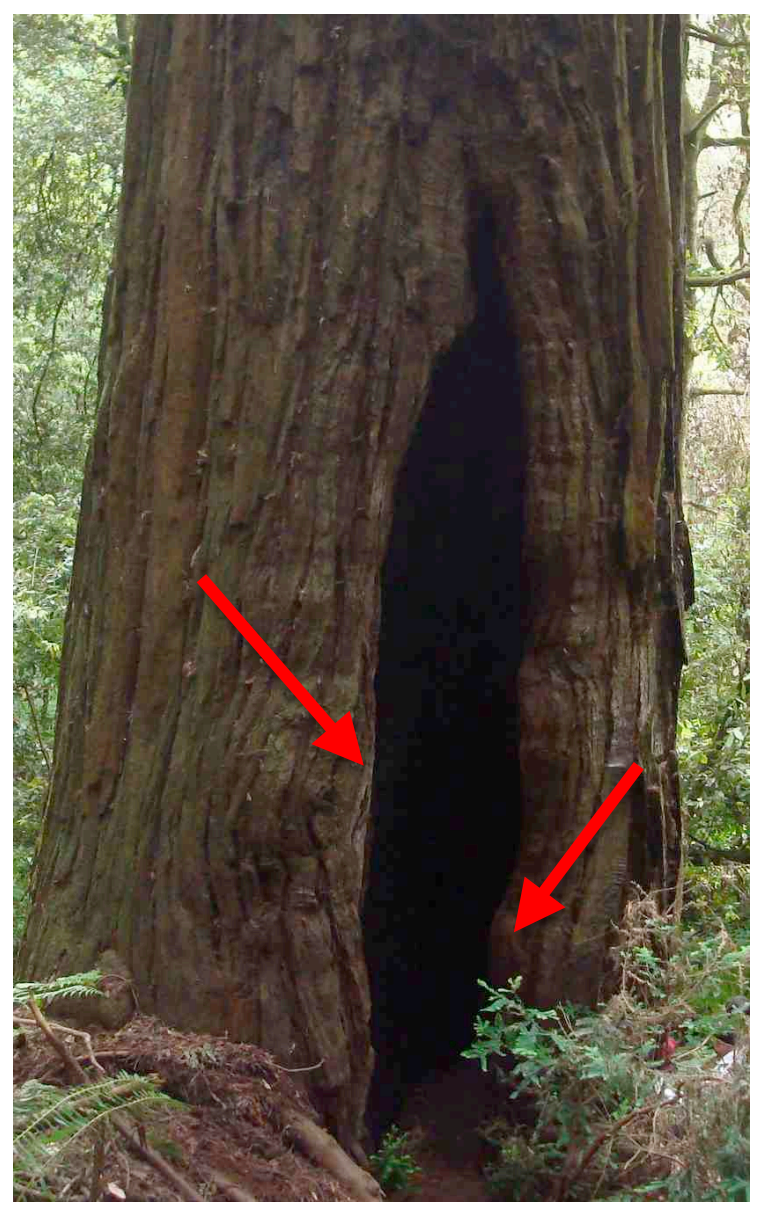

Figure 6. Fire hollow.

Arrows point to woodwound.

\section{Data Collection}

Stand level characteristics - height, DBH, number of stems, and fire hollows.

Russell and Woolhouse (2012) plotted 10 UTM coordinate points within each stratum

(Figure 5). Each coordinate was a $7 \mathrm{~m}$ diameter plot. In the extreme and short pygmy strata, the most dominant species were cypress and bolander pine; coast redwood dominance did not appear until the transitional strata (Russell \& Woolhouse, 2012). A survey was carried out to locate at least one coast redwood within these strata. It started 
in the center of the extreme pygmy stratum and circled out to the outer strata. Additional criteria were used to select individual trees for sampling, including climbing safety and significant canopy structures, such as large reiterations and epiphytic density. The study sought to characterize a representative sample of plots per strata. For every stratum, except the pygmy redwood stratum, all coast redwoods trees and clusters were characterized. In the pygmy redwood stratum, five plots were sampled. A Global Positioning System (GPS) was used to map the location of the sampled trees, and a code name was given.

Plot. Due to the uniqueness of the growth patterns of S. sempervirens within the study site, two definitions were used to define a plot. First, a lone tree was used as a plot if it was at least $2 \mathrm{~m}$ away from its nearest neighboring coast redwood. In areas where trees were clustered, a plot was defined as a group of trees within $2 \mathrm{~m}$ of each other. All the stems within each cluster were counted and grouped into height classes.

Height. The height of each tree was taken by using a measuring tape lowered from the highest foliage to the true ground. Sillett and Van Pelt (2007) describe true ground as the point equal to the average between the lowest and highest part of the base of the tree without tree litter or debris against the trunk. The height of trees that were not accessible through climbing or a ladder was measured using a Suunto Clinometer (Finland).

Diameter at breast height. The diameter of the main trunk of each tree was measured at $1.37 \mathrm{~m}(\mathrm{DBH})$ from the true ground using a forester diameter tape. 
Soil sample. Soil samples were collected $1 \mathrm{~m}$ from the base of the sampled tree, $10 \mathrm{~cm}$ below true ground. In plots where stem density was high, the sample was taken $1 \mathrm{~m}$ from the plot boundary. A marked $1 \mathrm{~m}$ probe was used to measure the duff layer depth. The soil sample point was selected based on accessibility, considering such factors as dense vegetation, large roots, and safety. A full bucket (approximately $450 \mathrm{ml}$ ) from a soil auger was collected and sent to A \& L Western Agricultural Laboratories (Modesto, California) for analysis. The following soil properties were analyzed: percent of organic matter, phosphorus (Weak Bray and Sodium Bicarbonate-P), parts per million (ppm) of extractable cations (potassium, magnesium, calcium, sodium), hydrogen, sulfate-S (ppm), $\mathrm{pH}$, cation exchange capacity (meq/100g), and percent cation saturation (computed). The soil analysis sample report with reference guide explanations from A \& L Plains Labs, Inc. describe the weak Bray test, P1, as the most accurate for soils with low $\mathrm{pH}$, and an ideal level of $\mathrm{P}$ is between $20 \mathrm{ppm}$ and $30 \mathrm{ppm}$. Water-holding capacity was measured using a FieldScout TDR 200 (Spectrum Technologies, Inc., Plainfield, Illinois) in January 2012. This device measures water-holding capacity by calculating the traveling time of an electromagnetic waveguide, which is dependent on the porosity and permeability of the soil.

Number of stems. All trees, poles, saplings, and seedlings within each plot were counted and placed into a height class. For the purposes of this study, a tree was defined as having a DBH greater than $30.48 \mathrm{~cm}$, following the Forest Service glossary for timber harvesting (Stokes, Ashmore, Rawlings, \& Sirois, 1989). A pole was taller than $1.37 \mathrm{~m}$ with a DBH between $10.16 \mathrm{~cm}$ and $30.48 \mathrm{~cm}$. A sapling was taller than $1.37 \mathrm{~m}$ with a 
DBH less than $10.16 \mathrm{~cm}$, and a seedling was less than $1.37 \mathrm{~m}$ tall. The term "stem" is a more general term for all the following: tree, pole, sapling, and/or seedling. A sprout is a clonal stem. A root bole is a composite of stems originating from the same rootstock. If the number of stems per plot was greater than 50 , the stems were placed in height classes. Then one stem was selected and characterized on ground and canopy characteristics.

Fire hollows. Fire hollows were measured with a $15 \mathrm{~m}$ measuring tape. The internal height and depth was measured, as well as the width of the opening. The width of the opening was measured at the widest point of the opening. The volume of the fire hollow $=$ height $\times$ depth $\times$ width $($ Zielinski \& Gellman, 1999, p. 162). If a sample tree had no fire hollow, but showed signs of fire scars, it was noted.

\section{Canopy characteristics - Canopy complexity, epiphytic vascular plants, and}

arboreal soils. Tree canopy characteristics were measured by climbing tall trees that were inaccessible from the ground by using the International Society of Arboriculture climbing techniques (Lilly, 2010). A shot pouch was thrown with an attached target line over a live stable branch between $15 \mathrm{~m}$ to $20 \mathrm{~m}$ above ground level, followed by a $15 \mathrm{~mm}$ thick climbing rope tied to the end of the target line, and pulled over the branches. One end of the rope was anchored to the base of the tree and the other end was used for ascending to the canopy, via a set of ascenders. Movement within the canopy was done by securing a $30 \mathrm{~m}$ rope in a higher stable branch, and using a Blake's hitch knot. Sillett and Van Pelt (2000a, 2000b, 2007) and Ellyson and Sillett (2003) used similar methods in accessing the canopy of taller trees. Prior to accessing the canopy of a tree, tree assessments were made to ensure that disturbance to wildlife was avoided. Trees $\leq 3 \mathrm{~m}$ in 
height were accessed using an extension ladder; movement within the canopy was not necessary.

Reiterations. Canopy complexity was measured following Van Pelt and Sillett's (2008) appendage hierarchy, used to identify hierarchical rank. A lettering system for reiterations was used to help evaluate the complexity of the canopy (Van Pelt \& Sillett, 2008). Each letter was assigned to represent a rank; the highest rank was the main trunk and the lowest rank was a branch, which was always the terminal bud of a combination of appendage structures. For example, the combination "BRLRT" is a branch (B) off a reiterated trunk $(\mathrm{R})$ off a limb $(\mathrm{L})$ off another reiterated $(\mathrm{R})$ trunk off the main trunk $(\mathrm{T})$. Thus, the final branch represents the terminal bud, and the main trunk is always the parent of the entire structure. Limbs grow perpendicular to the main trunk, where reiterated trunks grow parallel to the main trunk. A structure originating from the main trunk with a basal diameter less than $12.7 \mathrm{~cm}$ was not included in the study.

Arboreal soils. Using Sillett and Van Pelt's (2007) method of measuring arboreal soil depth and volume, a measured and marked probe was inserted perpendicular to the surface of the substrate; the average of three depth measurements was recorded as the depth. The width and length of the substrate was measured to calculate the surface area $\left(\pi r_{1} r_{2}\right)$, where $r_{1}=\operatorname{radius}_{1}$ and $r_{2}=$ radius 2. The substrate was treated as an ellipse. Using the depth measurements, the volume (surface area $\times$ depth) was calculated (Sillett $\&$ Van Pelt, 2007). 
Epiphytes. Each live vascular plant established on the canopy (branch, limb, reiteration, and main trunk) was counted, identified, and located within the branch hierarchies.

\section{Data Analysis}

All statistical analyses were done using SPSS (Version 19). A Pearson's Correlation Coefficient (r) was done as a preliminary test to measure independence between variables and shared variation. A correlation was considered strong if $r \geq .50$, or $\leq-.50$. The correlation was considered significant if $p<.05$. If the relationship was strong and significant, it was followed by a multiple stepwise linear regression analysis to obtain a predictive model. Adjusted R Square was used to measure what percentage of the variation in the data was explained by that model and whether the model predicted a significant amount of the variation $(p<.05)$. In stepwise linear regression "Adjusted $\mathrm{R}$ Square" was reported since more than two predictor variables were being entered in the analysis. R Square increases with the number of variables, and the adjusted R Square adjusts for the increase in variable in the model. Ideally, the model must be applicable to the general population and not just the sampled population. 


\section{RESULTS}

A total of 16 plots (Figure 7) were characterized from the center of extreme pygmy vegetation to pygmy redwoods. Five trees were climbed for canopy access, and in some cases no equipment was required due to their short heights. 


\section{Russell Unit Of the Mendocino Headlands State Park Mendocino, CA}

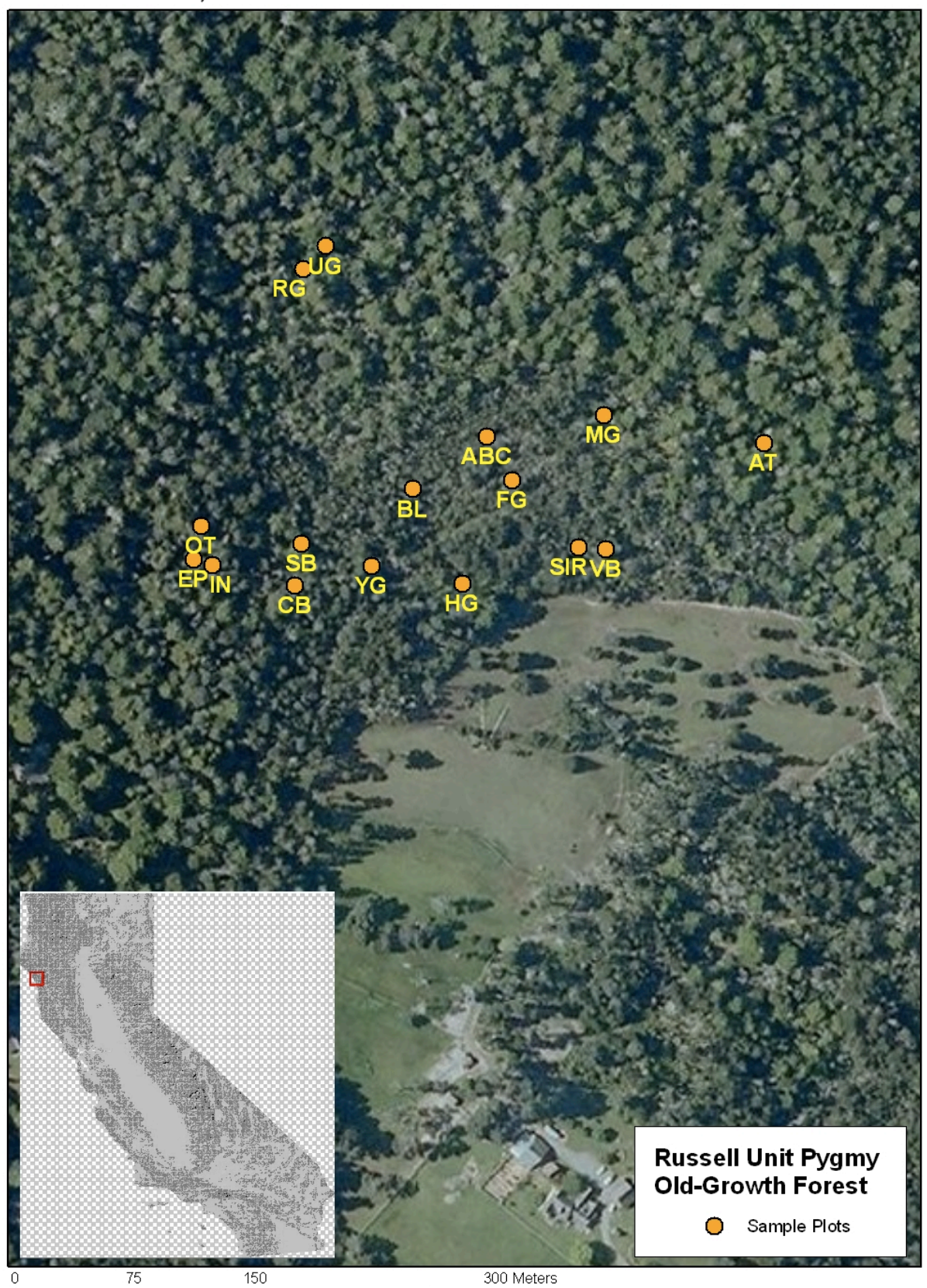

Map Developed by Elizabeth Lanham

Aerial imagery courtesy ESRI ArcGIS Online and data partners, including imagery from agencies supplied via the Content Sharing Program

Figure 7. Map of 16 sampled plots within the Russell Unit.

$\mathrm{ABC}=\mathrm{ABC}, \mathrm{BL}=\mathrm{Big} \mathrm{L}, \mathrm{FG}, \mathrm{SIR}=$ Sibling Rivalry, $\mathrm{VB}=$ Vagabond, $\mathrm{HG}=$ Hogs Grove, $\mathrm{YG}$,

$\mathrm{SB}=$ Santa Barbara, $\mathrm{CB}=$ Charles Grove, $\mathrm{IN}=$ Inish Man, $\mathrm{EP}=\mathrm{El}$ Patron, OT $=$ Owl Tree, $\mathrm{RG}=$ Russell Grove, $\mathrm{UG}=$ Umbrella Grove, and AT = Athena 


\section{Statistical Analysis of Plot Data}

Analysis of Maximum Tree Height and Soil Properties. Obvious stunted

growth was observed in plots in the extreme pygmy stratum through the tall pygmy and into the transitional stratum. Umbrella Grove plot was the only plot to have weak trunks, with a lean so significant that the tip of the "top" of the tree could be reached from the forest floor.

The Pearson's correlations (Appendix A) showed a significant and strong relationship between total height and phosphorous $\left(r_{4}=.553, p=.013\right)$, potassium $\left(r_{4}=.677, p=.002\right)$, calcium $\left(r_{4}=.598, p=.007\right)$, and CEC $\left(r_{4}=.666, p=.002\right)$. After running a stepwise linear regression (Tables 1, 2, and 3) using coast redwood height as the dependent variable and soil properties as the independent variables, it identified that potassium $(p=.002)$ and water-holding capacity $(p=.027)($ Table 1$)$ were significant predictors of height, $F_{(2,13)}=11.258, p=.001$ (Table 2, Figures 8 and 9). This model is consistent with soil nutrient interactions since $\mathrm{K}$ becomes unavailable to the plant if CEC increases, which can result from water-holding capacity increasing. The model accounted for $57.8 \%$ of the variation in the data (Table 3). Together, $\mathrm{K}$ and water holding capacity were better predictors of maximum height, than $\mathrm{pH}$ levels, $\mathrm{Ca}, \mathrm{Mg}, \mathrm{P}$, $\mathrm{Na}$, and CEC. More than $50 \%$ of the variation exists in the population. 
Table 1

Height stepwise predictive model

\begin{tabular}{|c|c|c|c|c|c|c|}
\hline \multicolumn{7}{|c|}{ Coefficients(a) } \\
\hline & \multirow[b]{2}{*}{ Model } & \multicolumn{2}{|c|}{$\begin{array}{c}\text { Unstandardized } \\
\text { Coefficients }\end{array}$} & \multirow{2}{*}{$\begin{array}{c}\text { Standardized } \\
\text { Coefficients } \\
\text { Beta }\end{array}$} & \multirow[b]{2}{*}{$\mathrm{t}$} & \multirow[b]{2}{*}{ Sig. } \\
\hline & & B & $\begin{array}{l}\text { Std. } \\
\text { Error }\end{array}$ & & & \\
\hline \multirow{2}{*}{1} & (Constant) & 1.115 & 4.611 & & 0.242 & .812 \\
\hline & $\mathrm{K}$ ppm & 0.274 & 0.08 & 0.677 & 3.443 & .004 \\
\hline \multirow{4}{*}{2} & (Constant) & 15.452 & 6.962 & & 2.219 & .045 \\
\hline & $\mathrm{K}$ ppm & 0.262 & 0.068 & 0.647 & 3.846 & .002 \\
\hline & $\begin{array}{l}\text { Water } \\
\text { Holding }\end{array}$ & & & & & \\
\hline & Capacity & -0.493 & 0.197 & -0.42 & -2.496 & .027 \\
\hline
\end{tabular}

\section{Table 2}

Height model significance

\begin{tabular}{clccccc}
\hline \multicolumn{7}{c}{ ANOVA(c) } \\
\hline \multirow{2}{*}{1} & Model & Sum of Squares & df & Mean Square & F & Sig. \\
\hline \multirow{2}{*}{2} & Regression & 1115.037 & 1 & 1115.037 & 11.857 & $.004 \mathrm{a}$ \\
& Residual & 1316.54 & 14 & 94.039 & & \\
& Total & 2431.577 & 15 & & & \\
\hline \multirow{2}{*}{2} & Regression & 1541.559 & 2 & 770.779 & 11.258 & $.001 \mathrm{~b}$ \\
& Residual & 890.018 & 13 & 68.463 & & \\
& Total & 2431.577 & 15 & & & \\
\hline
\end{tabular}

Note. The model two explained a higher significant amount of the variation, $p=.001$
a. Predictors: (Constant), K ppm
b. Predictors: (Constant), K ppm, Water Holding Capacity
c. Dependent Variable: Maximum Height 
Table 3

Height adjusted $R$ square

\begin{tabular}{ccccc}
\hline \multicolumn{5}{c}{ Model Summary(c) } \\
\hline Model & R & R Square & $\begin{array}{c}\text { Adjusted R } \\
\text { Square }\end{array}$ & $\begin{array}{c}\text { Std. Error of the } \\
\text { Estimate }\end{array}$ \\
\hline 1 & $.677 \mathrm{a}$ & .459 & .420 & 9.69735 \\
2 & $.796 \mathrm{~b}$ & .634 & .578 & 8.27423 \\
\hline
\end{tabular}

Note. The maximum height predictive model two accounted for .578 of the variation in the data

a. Predictors: (Constant), K ppm

b. Predictors: (Constant), K ppm, Water Holding Capacity

c. Dependent Variable: Maximum Height

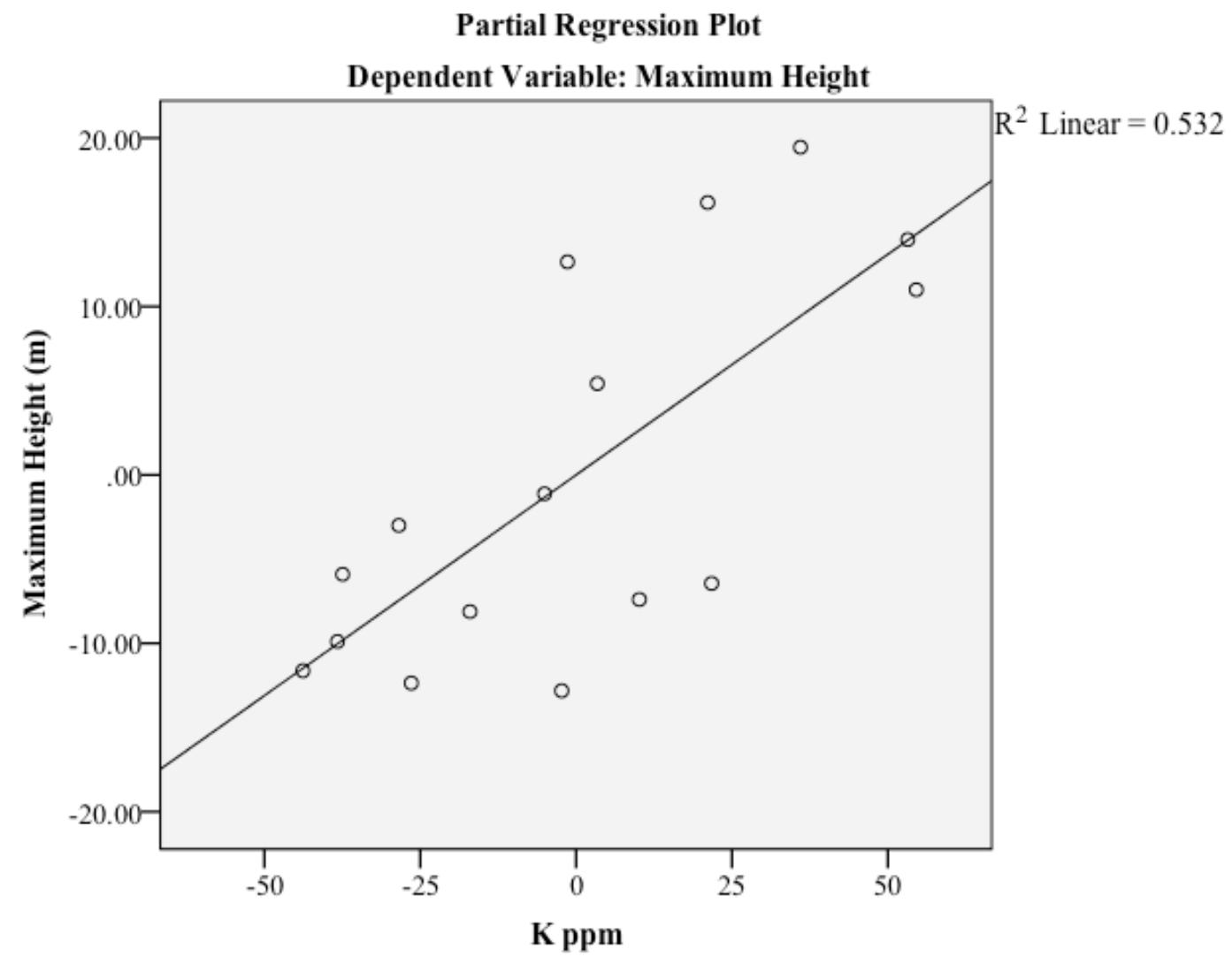

Figure 8. Tree height and potassium stepwise linear regression partial scatter plot. Best-fit line, maximum height on $\mathrm{y}$-axis and $\mathrm{K}$ ppm on $\mathrm{x}$-axis $(p=.002)$. 


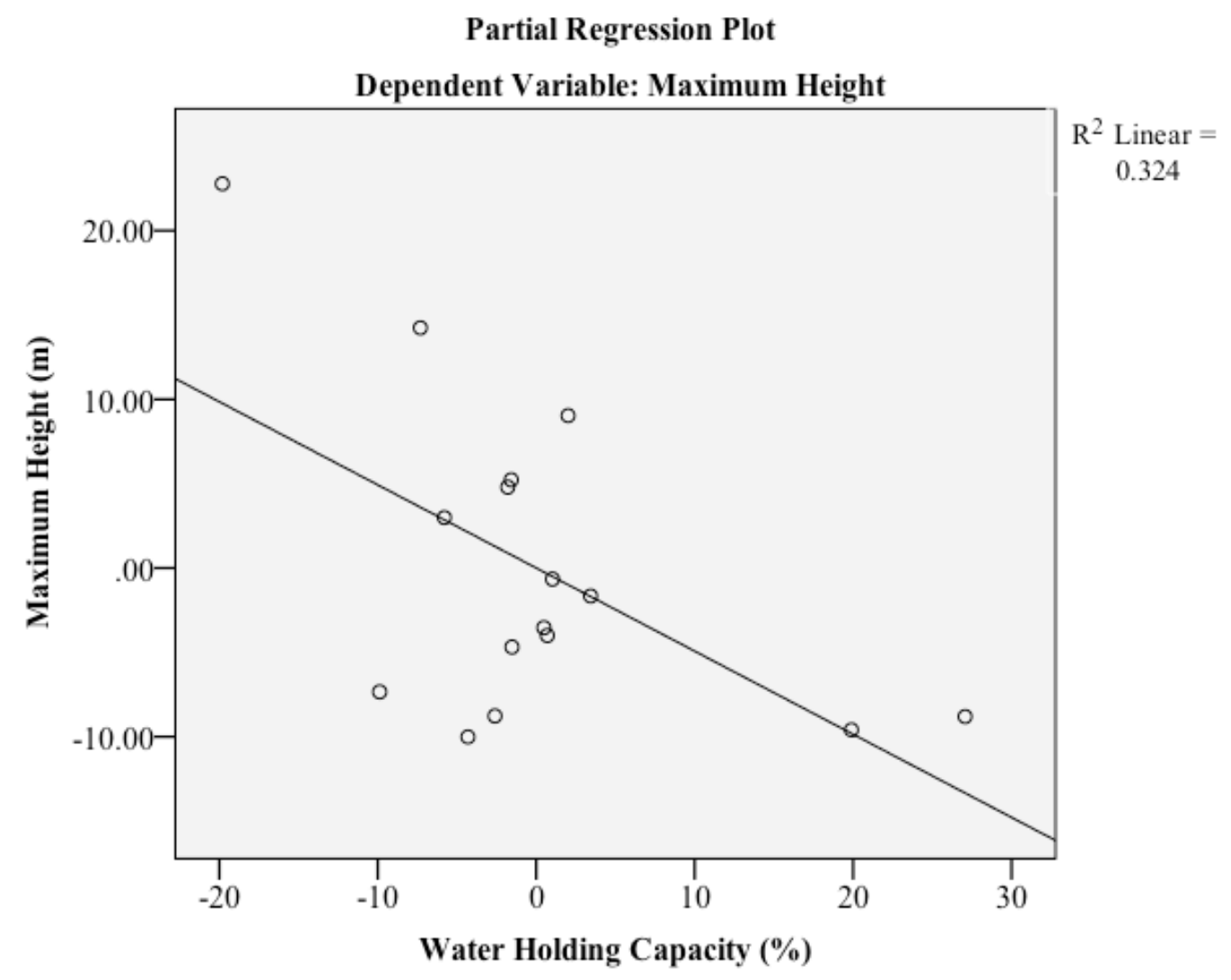

Figure 9. Tree height and water-holding capacity stepwise linear regression partial scatter plot.

Best fit line, maximum height on $\mathrm{y}$-axis and water holding capacity on $\mathrm{x}$-axis $(p=.027)$.

Analysis of Maximum Tree Diameter and Soil Properties. The Pearson's correlation output (Appendix B) showed that like stem height, DBH had a strong and significant positive relationship with phosphorous $\left(r_{4}=.517, p=.02\right)$, potassium $\left(r_{4}=.761, p<.001\right)$, calcium $\left(r_{4}=.619, p=.005\right)$, CEC $\left(r_{4}=.726, p<.001\right)$, and sodium $\left(r_{4}=.523, p=.049\right)$. However, CEC $(p<.001)$ and $\mathrm{P}(p=.008)$ (Table 4) were significant predictors of stem diameter, $F_{(2,13)}=20.716, p<.001$ (Table 5). Model 2 accounted for $72.4 \%$ of the variation in the data (Table 6) (Figures 10 and 11). The CEC 
levels did not uniformly increase throughout the strata. The lowest CEC was measured in the short pygmy stratum in the YG plot $(1.7 \mathrm{meq} / 100 \mathrm{~g})$, and the highest was measured in the pygmy redwood stratum in the Owl Tree plot $(13.1 \mathrm{meq} / 100 \mathrm{~g})$. The latter had the highest percentage of organic matter, which can potentially increase soil acidity, thus decreasing CEC. All plots had very low levels of P. Plot Athena had the highest level of $\mathrm{P}(12 \mathrm{ppm})$ and had the third largest DBH $(1.59 \mathrm{~m})$. The lowest levels of $\mathrm{P}(1 \mathrm{ppm})$ were in the Big L, YG, and Charles Grove plots, which were all in different strata. In the extreme pygmy, Big L had a maximum DBH of $4 \mathrm{~cm}$, followed by the $\mathrm{YG}$ plot in the short pygmy stratum $(58 \mathrm{~cm})$, and Charles Grove $(37.85 \mathrm{~cm})$ in the tall pygmy stratum. However, the difference in P ppm between the extreme pygmy stratum and the pygmy redwood stratum was not very substantial, with the exception of the Athena plot. The average DBH in the extreme pygmy was $8 \mathrm{~cm}$. Inish Man had the largest DBH out of all 16 plots $(2.3 \mathrm{~m})$ with $5 \mathrm{ppm}$ of $\mathrm{P}$. 
Table 4

DBH stepwise predictive model

\begin{tabular}{|c|c|c|c|c|c|c|}
\hline \multicolumn{7}{|c|}{ Coefficients(a) } \\
\hline & \multirow[b]{2}{*}{ Model } & \multicolumn{2}{|c|}{$\begin{array}{c}\text { Unstandardized } \\
\text { Coefficients }\end{array}$} & \multirow{2}{*}{$\begin{array}{c}\text { Standardized } \\
\text { Coefficients } \\
\text { Beta }\end{array}$} & \multirow[b]{2}{*}{$\mathrm{t}$} & \multirow[b]{2}{*}{ Sig. } \\
\hline & & B & $\begin{array}{l}\text { Std. } \\
\text { Error }\end{array}$ & & & \\
\hline \multirow{2}{*}{1} & (Constant) & 0.066 & 0.2 & & 0.33 & .746 \\
\hline & $\mathrm{CEC}$ & 0.145 & 0.033 & 0.761 & 4.392 & .001 \\
\hline \multirow{3}{*}{2} & (Constant) & -0.29 & 0.193 & & -1.503 & .157 \\
\hline & CEC & 0.135 & 0.026 & 0.708 & 5.187 & .000 \\
\hline & P ppm & 0.113 & 0.036 & 0.43 & 3.145 & .008 \\
\hline
\end{tabular}

Note. Maximum DBH $=-0.290+0.135(\mathrm{CEC})+0.113(\mathrm{P} \mathrm{ppm})$

a. Dependent Variable: Maximum DBH

Table 5

DBH model significance

\begin{tabular}{llccccc}
\hline & \multicolumn{7}{c}{ ANOVA(c) } \\
\hline & Model & Sum of Squares & df & Mean Square & F & Sig. \\
\hline \multirow{2}{*}{1} & Regression & 4.759 & 1 & 4.759 & 19.291 & $.001 \mathrm{a}$ \\
& Residual & 3.454 & 14 & 0.247 & & \\
& Total & 8.213 & 15 & & & \\
\hline \multirow{2}{*}{2} & Regression & 6.252 & 2 & 3.126 & 20.716 & $.000 \mathrm{~b}$ \\
& Residual & 1.962 & 13 & 0.151 & & \\
& Total & 8.213 & 15 & & & \\
\hline
\end{tabular}

Note. The model explained a significant amount of the variation, $p<.001$

a. Predictors: (Constant), CEC meq/100g

b. Predictors: (Constant), CEC meq/100g, P ppm

c. Dependent Variable: Maximum DBH 
Table 6

DBH adjusted $R$ square

\begin{tabular}{ccccc}
\hline \multicolumn{5}{c}{ Model Summary(c) } \\
\hline Model & $\mathrm{R}$ & $\mathrm{R}$ & $\begin{array}{c}\text { Adjusted R } \\
\text { Square }\end{array}$ & $\begin{array}{c}\text { Std. Error of the } \\
\text { Square }\end{array}$ \\
\hline 1 & $.761 \mathrm{a}$ & .579 & .549 & 0.4967 \\
2 & $.872 \mathrm{~b}$ & .761 & .724 & 0.38845 \\
\hline
\end{tabular}

Note. The maximum DBH predictive model two accounted for .72 4 of the variation in the data
a. Predictors: (Constant), CEC meq/100g
b. Predictors: (Constant), CEC meq/100g, P ppm
c. Dependent Variable: Maximum DBH

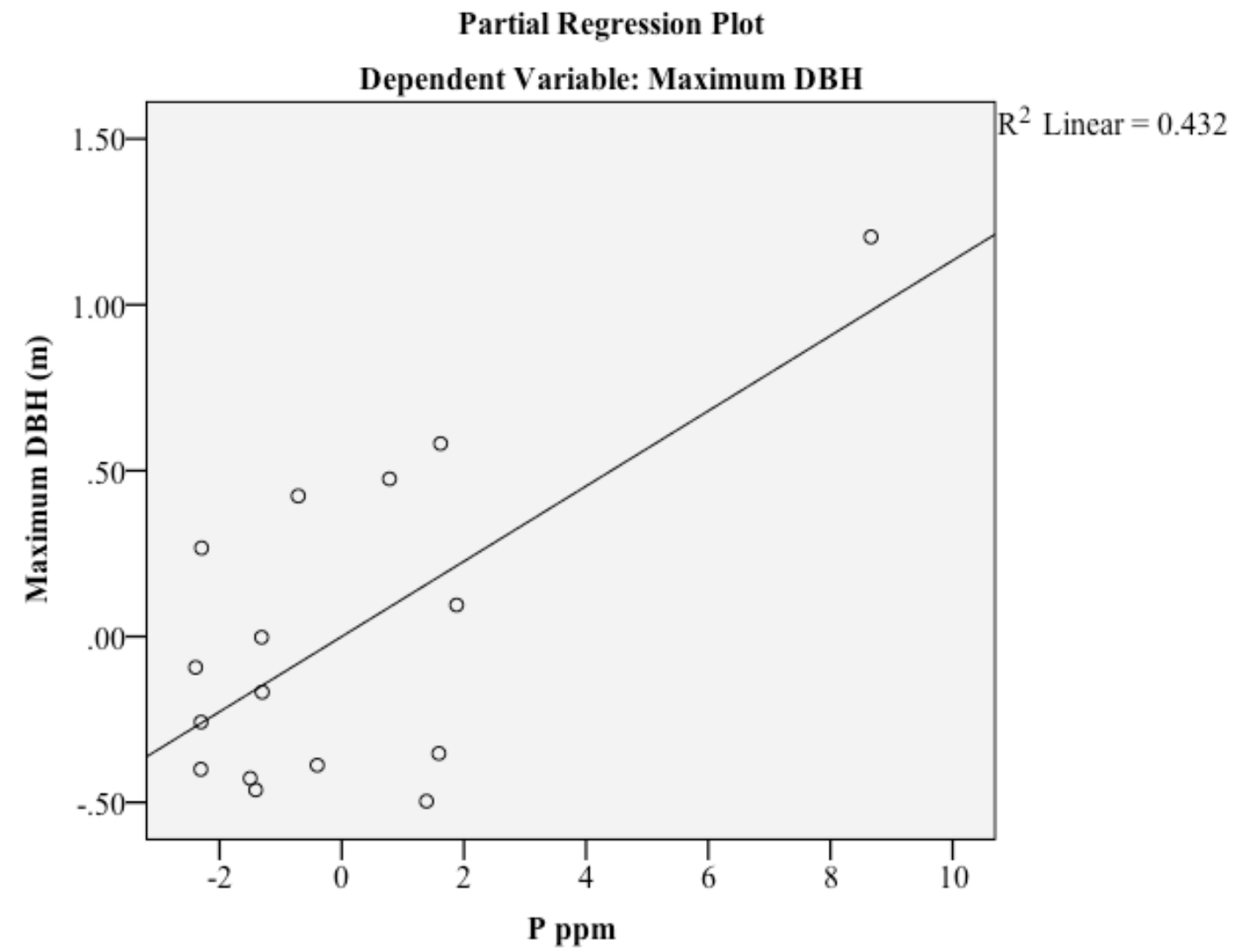

Figure 10. DBH and phosphorous stepwise linear regression partial scatter plot. Best fit line, maximum DBH on $\mathrm{y}$-axis and $\mathrm{P}$ ppm on $\mathrm{x}$-axis $(p=.008)$. 


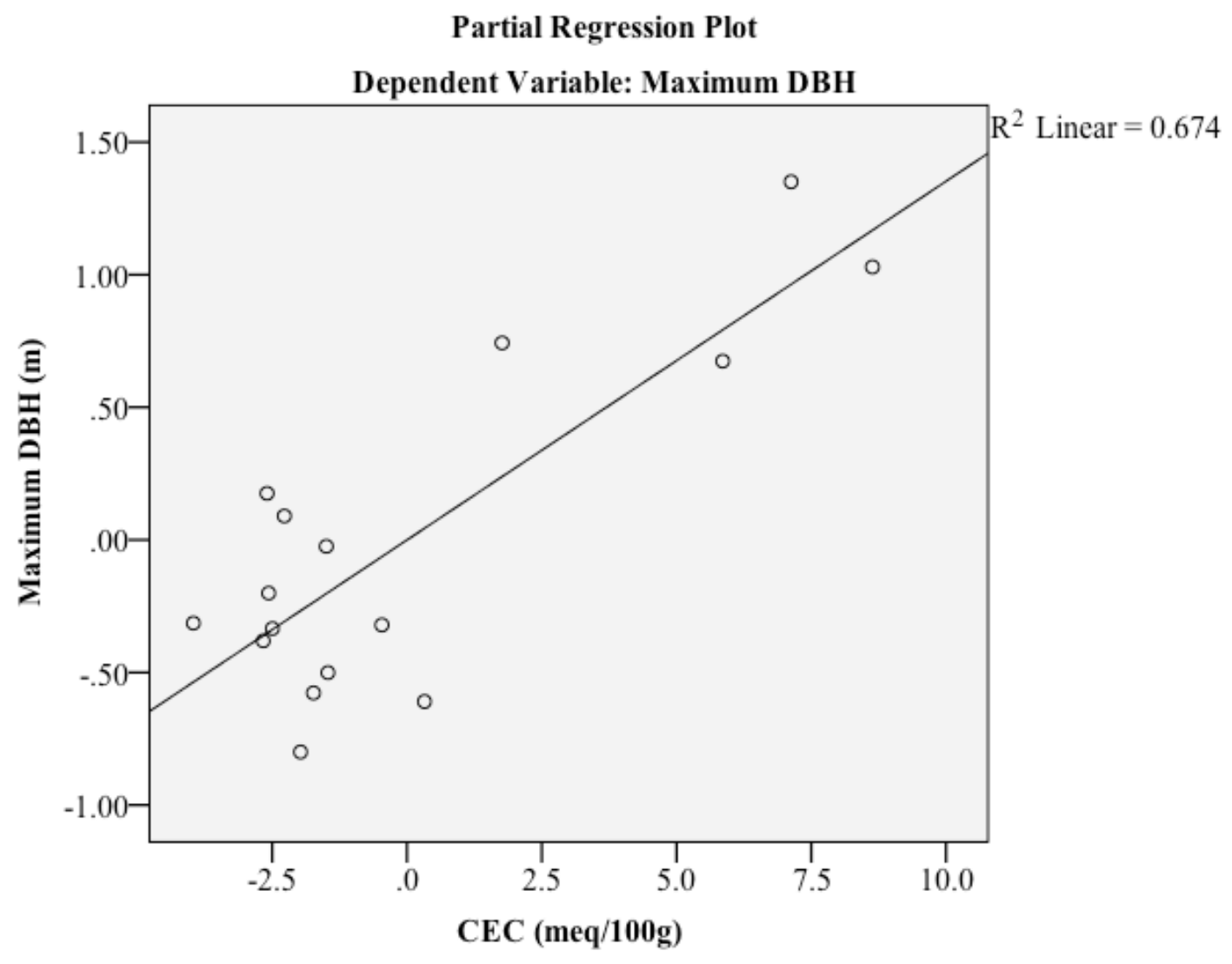

Figure 11. DBH and cation exchange capacity stepwise linear regression partial scatter plot.

Maximum DBH on $\mathrm{y}$-axis and CEC on $\mathrm{x}$-axis $(p<.001)$.

Analysis of Stand Density and Soil Properties. The number of stems per plot was not correlated to soil properties. The Pearson's correlation coefficient was neither strong nor significant for any of the independent variables (Appendix C). Further analyses were carried out with variables that can potentially have an effect on the number of stems per plot, such as maximum height, maximum DBH, and fire hollows; soil properties were excluded. These variables were selected due to forests' natural processes such as competition for resource availability, productivity, and disturbances. 
Height $(p=.038)$ (Table 7) was a significant predictor of the number of stems per plot, $F_{(1,3)}=12.672, p=.038$ (Table 8$)$. The model also accounted for $74.5 \%$ of the data (Table 9). The relationship between stem height and number of stems was negative; as height increased the number of stems decreased (Figure 12). It was unclear as to why soil properties did not influence the number of stems within each plot, since the boundaries in plots with more than one coast redwood were very clear and obvious. It can be surmised that height negatively influences stem density since the higher the density of species, the more competition there is for resources, thereby, retarding growth and allocating energy for conservation.

Table 7

Number of stems per plot stepwise predictive model

\begin{tabular}{|c|c|c|c|c|c|c|}
\hline \multicolumn{7}{|c|}{ Coefficients(a) } \\
\hline & \multirow[b]{2}{*}{ Model } & \multicolumn{2}{|c|}{$\begin{array}{c}\text { Unstandardized } \\
\text { Coefficients }\end{array}$} & \multirow{2}{*}{$\begin{array}{c}\text { Standardized } \\
\text { Coefficients } \\
\text { Beta } \\
\end{array}$} & \multirow[b]{2}{*}{$\mathrm{t}$} & \multirow[b]{2}{*}{ Sig. } \\
\hline & & B & $\begin{array}{l}\text { Std. } \\
\text { Error }\end{array}$ & & & \\
\hline \multirow[b]{2}{*}{1} & (Constant) & 17.62 & 3.458 & & 5.095 & .015 \\
\hline & $\begin{array}{l}\text { Maximum } \\
\text { Height }\end{array}$ & -0.426 & 0.12 & -0.899 & -3.56 & .038 \\
\hline
\end{tabular}

Note. Predictive model for Sequoia sempervirens, number of trees and stems per plot $=17.62-0.426$ (Maximum Height)

a. Dependent Variable: Number of Stems Per Plot 


\section{Table 8}

\section{Number of stems per plot model significance}

\begin{tabular}{ccccccc}
\hline \multicolumn{8}{c}{ ANOVA(b) } \\
\hline & Model & Sum of Squares & df & Mean Square & F & Sig. \\
\hline \multirow{3}{*}{1} & Regression & 105.762 & 1 & 105.762 & 12.672 & $.038 \mathrm{a}$ \\
& Residual & 25.038 & 3 & 8.346 & & \\
& Total & 130.8 & 4 & & & \\
\hline
\end{tabular}

Note. The model explained a significant amount of the variation, $p=.038$

a. Predictors: (Constant), Maximum Height

b. Dependent Variable: Number of Stems Per Plot

Table 9

Number of stems per plot adjusted $R$ square

\begin{tabular}{ccccc}
\hline \multicolumn{5}{c}{ Model Summary(b) } \\
\hline Model & $\mathrm{R}$ & $\mathrm{R}$ & $\begin{array}{c}\text { Adjusted R } \\
\text { Square }\end{array}$ & $\begin{array}{c}\text { Std. Error of the } \\
\text { Estimate }\end{array}$ \\
\hline 1 & $.899 \mathrm{a}$ & .809 & .745 & 2.889 \\
\hline
\end{tabular}

Note. The number of stems per plot predictive model accounted for .745 of the variation in the data a. Predictors: (Constant), Maximum Height

b. Dependent Variable: Number of Stems Per Plot 


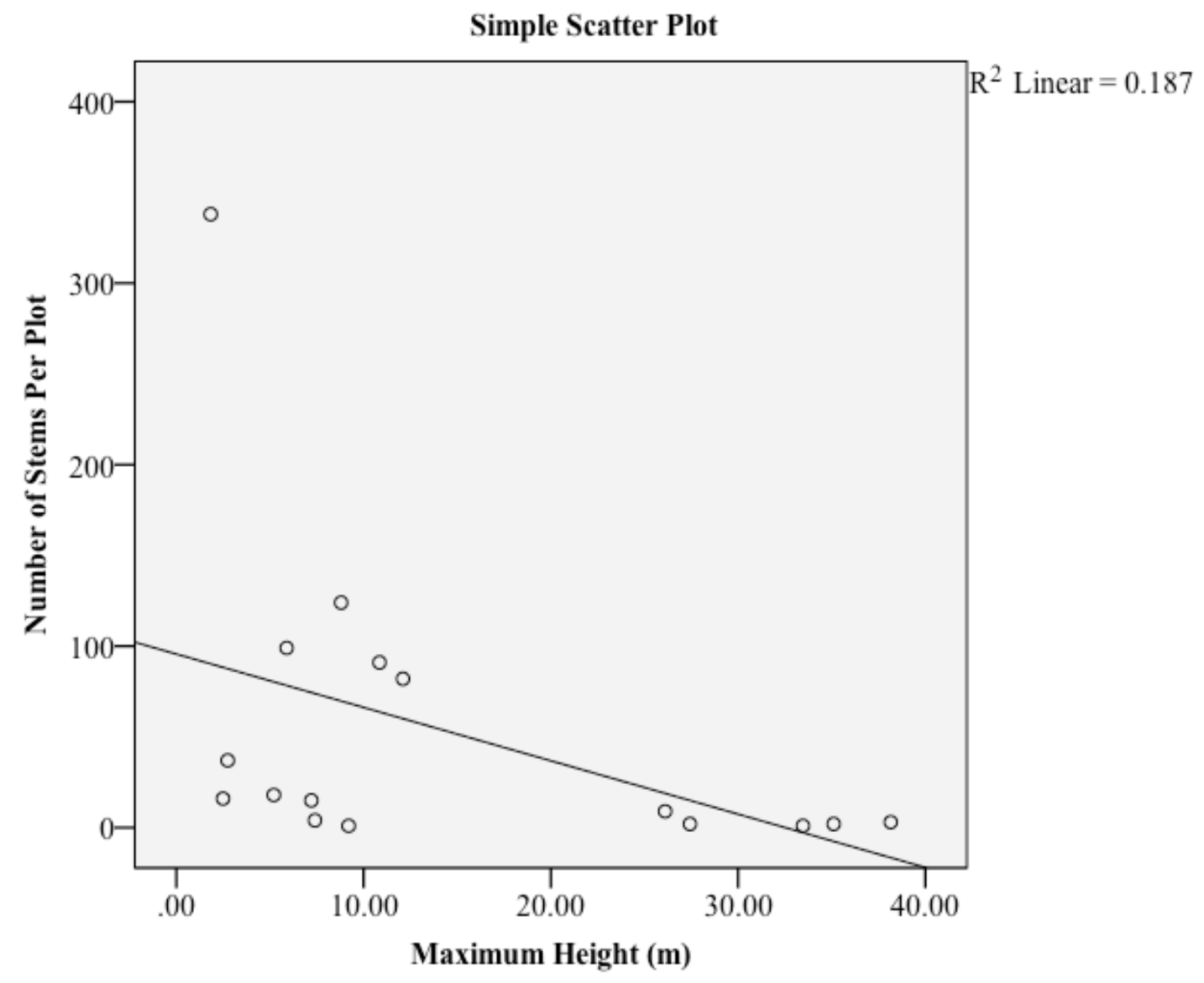

Figure 12. Number of stems per plot and maximum height simple scatter plot. Stems per plot on the $y$-axis and maximum height on the x-axis. The relationship is negative.

\section{Analysis of Fire Hollows, Soil Properties, and Tree Structures (DBH and}

Height). Five plots had fire hollows: Umbrella Grove, Russell Grove, Inish Man, Owl Tree, and Athena, all of which are in the transitional stratum and pygmy redwoods stratum. The tallest and largest trees were measured in these strata. Pearson's correlation showed fire hollow volume to be strongly and significantly correlated with sulfate $\left(r_{9}=.862, p=.030\right)$ and $\mathrm{K}\left(r_{9}=.877, p=.025\right)($ Appendix D). However, variables were 
not entered into a stepwise linear regression model due to a lack of predictability and significance. It is highly probable the small sample size was not sufficient for the statistical analysis.

\section{Analysis of Canopy Complexity, Soil Properties, and Tree Structures (Height}

and DBH). A total of seven plots had major canopy structures greater than $12.7 \mathrm{~cm}$ (reiterations, limbs, and branches). Except for the extreme pygmy stratum, canopy complexities were measured in the rest of the strata. These included YG, Charles Grove, Russell Grove, Inish Man, El Patron, Owl Tree, and Athena. The Pearson's correlation showed a strong and significant relationship between canopy complexities and $\mathrm{Ca}\left(r_{7}=.733, p=.031\right)$, maximum height $\left(r_{7}=.696, p=.041\right)$, and maximum DBH $\left(r_{7}=.728, p=.032\right)$ (Appendix E). However, a stepwise linear regression model was not created because the independent variables lacked predictability and significance, $p<.05$. For complex canopy structures to develop, wood volume also needs to develop and be able to hold its weight. However, during periods of Ca deficiencies, plant structures are weakened. Yet, the soil analyses showed very low ppm for $\mathrm{Ca}$ in the pygmy redwood stratum, which is the area in which the tallest and largest trees were recorded. The rest of the strata showed normal levels of $\mathrm{Ca}$. Ca levels could be the contributing factor for canopy complexity, but it is possible that this correlation is localized to the Russell Unit pygmy forest. 


\section{Analysis of Epiphytic Vascular Plants, Canopy Complexity and Ground}

Characteristics (Height, Fire Hollow Volumes, and DBH). A total of 363 epiphytes

were counted in eight plots. Inish Man was the tree with the highest number of epiphytes, which included Huckleberry (Vaccinium ovatum) and leather fern (Polypodium scouleri). In addition, Inish Man had the second highest hierarchical ranks (41). These numbers are approximations since characterization halted before it was complete, due to safety issues within the canopy. El Patron was the tree with the most hierarchical ranks (48), but it had only two recorded epiphytes. The Owl Tree had the third highest hierarchical ranks (11) and had 52 epiphytes. Canopy complexity was expected to be significantly correlated with the frequency of epiphytes. Person's correlation showed a strong and significant relationship between number of epiphytes and fire hollows $\left(r_{11}=.936, p=.019\right)$, and maximum DBH $\left(r_{11}=.636, p=.008\right)$ (Table 10). However, SPSS did not create a predictive model due to the lack of predictability and significance. Nevertheless, the number of epiphytes, maximum DBH, and fire hollow volume variables were entered into the stepwise linear regression model to further explore these relationships, excluding maximum height and canopy complexity. But the fire hollow volume $(p=.019)$ (Table 11) was a significant predictor of epiphytic density in the canopy, $F_{(1,3)}=21.279, p=.019$ (Table 12). The model explained $83.5 \%$ of the variation in the data (Table 13). It is probable during fires, seeds and organic debris are kicked up into the canopy and settle within it. In addition, it is highly probable fire hollows exist in trees with a larger DBH since they have a higher survival rate. However, 
the model produced for the number of epiphytes and DBH was significant but it failed to predict more than $50 \%$ of the variation in the data.

\section{Table 10}

Pearson's correlations between number of epiphytes, fire hollows, canopy complexities, and maximum $\mathrm{DBH}$ and tree height

\begin{tabular}{|c|c|c|c|c|c|c|}
\hline \multicolumn{7}{|c|}{ Correlations } \\
\hline & & $\begin{array}{l}\text { Number of } \\
\text { Epiphytes }\end{array}$ & $\begin{array}{l}\text { Fire Hollow } \\
\text { Volume }\end{array}$ & $\begin{array}{c}\text { Maximum } \\
\text { Height }\end{array}$ & $\begin{array}{l}\text { Maximum } \\
\text { DBH }\end{array}$ & $\begin{array}{c}\text { Canopy } \\
\text { Complexity }\end{array}$ \\
\hline \multirow{3}{*}{$\begin{array}{l}\text { Number of } \\
\text { Epiphytes }\end{array}$} & $\begin{array}{l}\text { Pearson } \\
\text { Correlation }\end{array}$ & 1 & .936 & .308 & .636 & .388 \\
\hline & Sig. (2-tailed) & & .019 & .245 & .008 & .39 \\
\hline & $\mathrm{N}$ & 16 & 5 & 16 & 16 & 7 \\
\hline \multirow{3}{*}{$\begin{array}{l}\text { Fire Hollow } \\
\text { Volume }\end{array}$} & $\begin{array}{l}\text { Pearson } \\
\text { Correlation }\end{array}$ & .936 & 1 & -.019 & .747 & .3 \\
\hline & Sig. (2-tailed) & .019 & & .976 & .147 & .7 \\
\hline & $\mathrm{N}$ & 5 & 5 & 5 & 5 & 4 \\
\hline \multirow{3}{*}{$\begin{array}{l}\text { Maximum } \\
\text { Height }\end{array}$} & $\begin{array}{l}\text { Pearson } \\
\text { Correlation }\end{array}$ & .308 & -.019 & 1 & .878 & .696 \\
\hline & Sig. (2-tailed) & .245 & .976 & & 0 & .082 \\
\hline & $\mathrm{N}$ & 16 & 5 & 16 & 16 & 7 \\
\hline \multirow{3}{*}{$\begin{array}{l}\text { Maximum } \\
\text { DBH }\end{array}$} & $\begin{array}{l}\text { Pearson } \\
\text { Correlation }\end{array}$ & .636 & .747 & .878 & 1 & .728 \\
\hline & Sig. (2-tailed) & .008 & .147 & 0 & & .064 \\
\hline & $\mathrm{N}$ & 16 & 5 & 16 & 16 & 7 \\
\hline \multirow{3}{*}{$\begin{array}{l}\text { Canopy } \\
\text { Complexity }\end{array}$} & $\begin{array}{l}\text { Pearson } \\
\text { Correlation }\end{array}$ & .388 & .3 & .696 & .728 & 1 \\
\hline & Sig. (2-tailed) & .39 & .7 & .082 & .064 & \\
\hline & $\mathrm{N}$ & 7 & 4 & 7 & 7 & 7 \\
\hline
\end{tabular}




\section{Table 11}

\section{Epiphytes stepwise predictive model}

\begin{tabular}{|c|c|c|c|c|c|c|}
\hline \multicolumn{7}{|c|}{ Coefficients (a) } \\
\hline & \multirow[b]{2}{*}{ Model } & $\begin{array}{r}\text { Unsta1 } \\
\text { Coet }\end{array}$ & $\begin{array}{l}\text { dized } \\
\text { ents }\end{array}$ & $\begin{array}{l}\text { Standardized } \\
\text { Coefficients }\end{array}$ & \multirow[b]{2}{*}{$\mathrm{t}$} & \multirow[b]{2}{*}{ Sig. } \\
\hline & & B & $\begin{array}{l}\text { Std. } \\
\text { Error }\end{array}$ & Beta & & \\
\hline \multirow[b]{2}{*}{1} & (Constant) & -7.742 & 27.05 & & -0.286 & .793 \\
\hline & $\begin{array}{l}\text { Fire Hollow } \\
\text { Volume }\end{array}$ & 11.986 & 2.598 & 0.936 & 4.613 & .019 \\
\hline
\end{tabular}

Note. Predictive model, Number of epiphytes $=-7.742+11.986$ (Fire Hollow Volume)

a. Dependent Variable: Number of Epiphytes

Table 12

Epiphytes model significance

\begin{tabular}{llccccc}
\hline \multicolumn{8}{c}{ ANOVA (b) } \\
\hline & Model & Sum of Squares & df & Mean Square & F & Sig. \\
\hline \multirow{2}{*}{1} & Regression & 47003.911 & 1 & 47003.911 & 21.279 & $.019 \mathrm{a}$ \\
& Residual & 6626.889 & 3 & 2208.963 & & \\
& Total & 53630.8 & 4 & & & \\
\hline
\end{tabular}

Note. The model explained a significant amount of the variation, $p=.019$

a. Predictors: (Constant), Fire Hollow Volume

b. Dependent Variable: Number of Epiphytes

\section{Table 13}

Epiphytes adjusted R square

\begin{tabular}{ccccc}
\hline \multicolumn{5}{c}{ Model Summary (b) } \\
\hline Model & $\mathrm{R}$ & $\mathrm{R}$ & $\begin{array}{c}\text { Adjusted R } \\
\text { Square }\end{array}$ & $\begin{array}{c}\text { Std. Error of the } \\
\text { Estimate }\end{array}$ \\
\hline 1 & $.936 \mathrm{a}$ & .876 & .835 & 47 \\
\hline
\end{tabular}

Note. The number of epiphytes predictive model accounted for .835 of the variation in the data a. Predictors: (Constant), Fire Hollow Volume

b. Dependent Variable: Number of Epiphytes 


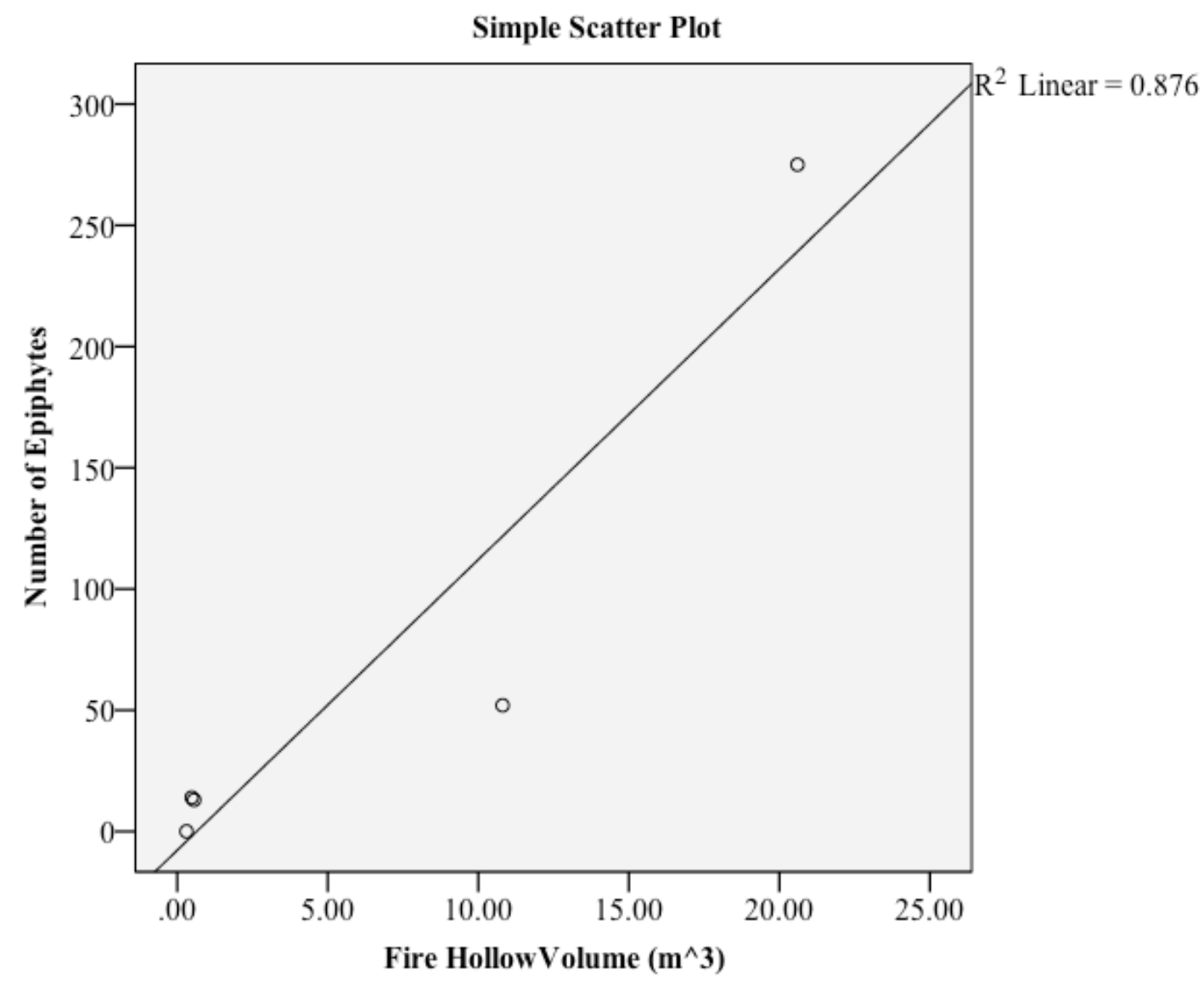

Figure 13. Number of epiphytes and fire hollow volume simple scatter plot. Stems per plot on the $\mathrm{x}$-axis and maximum height on $\mathrm{y}$-axis. Best fit line between number of epiphytes and fire hollows, $(p=.019)$.

\section{Plots - Soil Properties}

Results from the soil samples taken at each plot are presented in Tables 14 and 15. The percent cation saturation is the ratio of a cation in the CEC. The percent cation saturation of hydrogen was higher than the other nutrients in most of the plots. In some plots, $75 \%$ of the cation saturation was hydrogen. Furthermore, the soil $\mathrm{pH}$ levels throughout the site were relatively low, with Athena having the highest $\mathrm{pH}$ of 5.0 and the 
Santa Barbara plot having the lowest $\mathrm{pH}$ at 3.6. Russell Grove had the tallest tree,

$38.15 \mathrm{~m}$ with a $\mathrm{pH}$ of 3.8 , whereas in the extreme pygmy stratum the maximum height recorded was $2.74 \mathrm{~m}$, with a $\mathrm{pH}$ of 4.1 . Some of the lowest $\mathrm{pH}$ levels were found between the tall pygmy and pygmy redwood strata (Table 14).

Table 14

Cation exchange capacity and percent cation saturation in the 16 sampled plots

\begin{tabular}{|c|c|c|c|c|c|c|c|c|c|}
\hline \multirow[b]{2}{*}{ Strata } & \multirow{2}{*}{\multicolumn{2}{|c|}{$\begin{array}{c}\text { Organic } \\
\text { Matter } \\
\%\end{array}$}} & \multirow[b]{2}{*}{ pH } & \multirow[b]{2}{*}{$\begin{array}{c}\text { CEC } \\
\mathrm{meq} / 100 \mathrm{~g}\end{array}$} & \multicolumn{5}{|c|}{ Percent Cation Saturation } \\
\hline & & & & & $\begin{array}{l}\mathrm{K} \\
\%\end{array}$ & $\begin{array}{c}\mathrm{Mg} \\
\%\end{array}$ & $\begin{array}{l}\mathrm{Ca} \\
\%\end{array}$ & $\begin{array}{l}\mathbf{H} \\
\%\end{array}$ & $\begin{array}{l}\mathrm{Na} \\
\%\end{array}$ \\
\hline & $\mathrm{BL}$ & 1.5 & 4.0 & 1.8 & 0.7 & 7.6 & 12.1 & 75.0 & 4.7 \\
\hline Extreme & FG & 5.2 & 4.1 & 3.0 & 3.4 & 7.0 & 11.7 & 74.0 & 3.9 \\
\hline \multirow{2}{*}{ Pygmy } & $\mathrm{ABC}$ & 3.7 & 4.1 & 3.0 & 2.0 & 14.3 & 6.3 & 74.0 & 3.4 \\
\hline & SIR & 15.0 & 4.1 & 4.0 & 3.0 & 12.7 & 5.3 & 74.0 & 5.0 \\
\hline Short & YG & 3.3 & 3.9 & 1.7 & 2.6 & 8.5 & 9.2 & 75.0 & 4.7 \\
\hline \multirow[t]{4}{*}{ Pygmy } & VB & 1.5 & 4.1 & 1.8 & 1.6 & 11.1 & 9.3 & 74.0 & 4.0 \\
\hline & $\mathrm{MG}$ & 2.0 & 4.7 & 1.9 & 7.9 & 15.2 & 20.0 & 50.5 & 6.4 \\
\hline & $\mathrm{HG}$ & 4.5 & 5.3 & 5.3 & 3.5 & 14.0 & 49.7 & 31.0 & 1.9 \\
\hline & $\mathrm{CB}$ & 1.3 & 3.8 & 2.8 & 2.0 & 6.2 & 14.5 & 75.0 & 2.4 \\
\hline \multirow[t]{2}{*}{ Tall Pygmy } & SB & 3.9 & 3.6 & 2.9 & 2.8 & 10.2 & 6.6 & 75.0 & 5.3 \\
\hline & $\mathrm{RG}$ & 5.4 & 3.8 & 11.0 & 1.2 & 6.0 & 16.2 & 75.0 & 1.6 \\
\hline \multirow[t]{3}{*}{ Transitional } & UG & 2.4 & 4.7 & 2.7 & 4.7 & 9.8 & 30.5 & 50.5 & 4.6 \\
\hline & IN & 12.4 & 3.7 & 12.1 & 2.2 & 6.3 & 14.7 & 75.0 & 1.8 \\
\hline & EP & 2.6 & 4.3 & 6.4 & 3.4 & 8.5 & 20.0 & 66.0 & 2.1 \\
\hline Pygmy & OT & 23.3 & 3.7 & 13.1 & 2.0 & 8.6 & 11.6 & 75.0 & 2.8 \\
\hline Redwoods & $\mathrm{AT}$ & 2.1 & 5.0 & 2.2 & 8.5 & 10.2 & 35.6 & 41.0 & 4.6 \\
\hline
\end{tabular}


Table 15

Levels of soil nutrients and percentage of water holding capacity in the 16 sampled plots

\begin{tabular}{|c|c|c|c|c|c|c|c|}
\hline Stratum & Plot & $\begin{array}{c}\text { Water Holding } \\
\text { Capacity\% }\end{array}$ & $\begin{array}{c}* \text { Sulfate-S } \\
\mathrm{SO}_{4}-\mathrm{S} \\
\text { ppm }\end{array}$ & $\begin{array}{c}\sim P \\
\text { Weak Bray } \\
\text { ppm }\end{array}$ & $\begin{array}{c}* K \\
\text { ppm }\end{array}$ & $\begin{array}{l}* \mathbf{M g} \\
\text { ppm }\end{array}$ & $\begin{array}{l}{ }^{*} \mathrm{Ca} \\
\text { ppm }\end{array}$ \\
\hline & $\mathrm{BL}$ & 30 & $3 \mathrm{VL}$ & $1 \mathrm{VL}$ & 5 & 17 & 44 \\
\hline Extreme & FG & 48 & $6 \mathrm{~L}$ & $5 \mathrm{VL}$ & 40 & 26 & 71 \\
\hline \multirow[t]{3}{*}{ Pygmy } & $\mathrm{ABC}$ & 27 & $4 \mathrm{~L}$ & $2 \mathrm{VL}$ & 24 & 52 & 37 \\
\hline & SIR & 55 & $7 \mathrm{~L}$ & $2 \mathrm{VL}$ & 47 & 62 & 43 \\
\hline & YG & 23 & $5 \mathrm{~L}$ & $1 \mathrm{VL}$ & 17 & 18 & 31 \\
\hline \multirow[t]{4}{*}{ Short Pygmy } & VB & 27 & $4 \mathrm{~L}$ & $2 \mathrm{VL}$ & 12 & 25 & 34 \\
\hline & MG & 25 & $67 \mathrm{VH}$ & $2 \mathrm{VL}$ & 60 & 36 & 78 \\
\hline & HG & 23 & $5 \mathrm{~L}$ & $5 \mathrm{VL}$ & $72 \mathrm{M}$ & $90 \mathrm{M}$ & $526 \mathrm{~L}$ \\
\hline & $\mathrm{CB}$ & 27 & $4 \mathrm{~L}$ & $1 \mathrm{VL}$ & 21 & 21 & 80 \\
\hline \multirow[t]{2}{*}{ Tall Pygmy } & SB & 29 & $5 \mathrm{~L}$ & $3 \mathrm{VL}$ & 32 & 36 & 38 \\
\hline & $\mathrm{RG}$ & 8 & $8 \mathrm{~L}$ & $6 \mathrm{VL}$ & $52 \mathrm{~L}$ & $80 \mathrm{~L}$ & $357 \mathrm{VL}$ \\
\hline \multirow[t]{3}{*}{ Transitional } & UG & 18 & $4 \mathrm{~L}$ & $5 \mathrm{VL}$ & 49 & 32 & 164 \\
\hline & IN & 27 & $12 \mathrm{M}$ & $5 \mathrm{VL}$ & $104 \mathrm{M}$ & $92 \mathrm{~L}$ & $357 \mathrm{VL}$ \\
\hline & $\mathrm{EP}$ & 29 & $6 \mathrm{~L}$ & $3 \mathrm{VL}$ & $85 \mathrm{M}$ & $66 \mathrm{~L}$ & $255 \mathrm{VL}$ \\
\hline Pygmy & OT & 30 & $9 \mathrm{~L}$ & $2 \mathrm{VL}$ & $102 \mathrm{M}$ & $136 \mathrm{~L}$ & $303 \mathrm{VL}$ \\
\hline Redwoods & $\mathrm{AT}$ & 20 & $7 \mathrm{~L}$ & $12 \mathrm{~L}$ & 72 & 27 & 155 \\
\hline
\end{tabular}

Note. Ppm: parts per million

*A \& L Agricultural Laboratories code of amount ratings: Very Low (VL), Low (L), Medium (M), High $(\mathrm{H})$, and Very High $(\mathrm{VH})$. The values are based on the basic cation saturation ratios of balanced soils for a range of CEC levels (Table 14) developed by William Albrecht in the late 1950s. Ca $65-85 \%, \mathrm{Mg} 6-$ $12 \%$, and K $2-5 \%$ (Kopittke \& Menzies, 2007).

$\sim$ P levels are ideal between $20 \mathrm{ppm}$ and $30 \mathrm{ppm}$

The soil order throughout the study site varied from sand in the plots within the extreme pygmy stratum to silt loam in the first redwood stratum. In addition, the average water-holding capacity from the 16 plots was $27.88 \%$. The Russell Grove, located in the transitional stratum, had the lowest value of $8 \%$, whereas the highest value (48\%) was recorded on the extreme pygmy stratum in the FG plot (Figure 14).

The amount of sulfur in each plot was low, with the exception of Big L, McKenna Grove, and Inish Man (Table 15). The weak Bray test was used to measure P in each plot due to low pH levels (Tables 14 and 15). P levels in the plots were also rated as low or very low by A \& L Western Agriculture Laboratories, Inc. (Table 15). Potassium (K) 
levels throughout the plots were normal and medium, with the exception of the Russell Grove (RG), which was low in potassium (52 ppm).

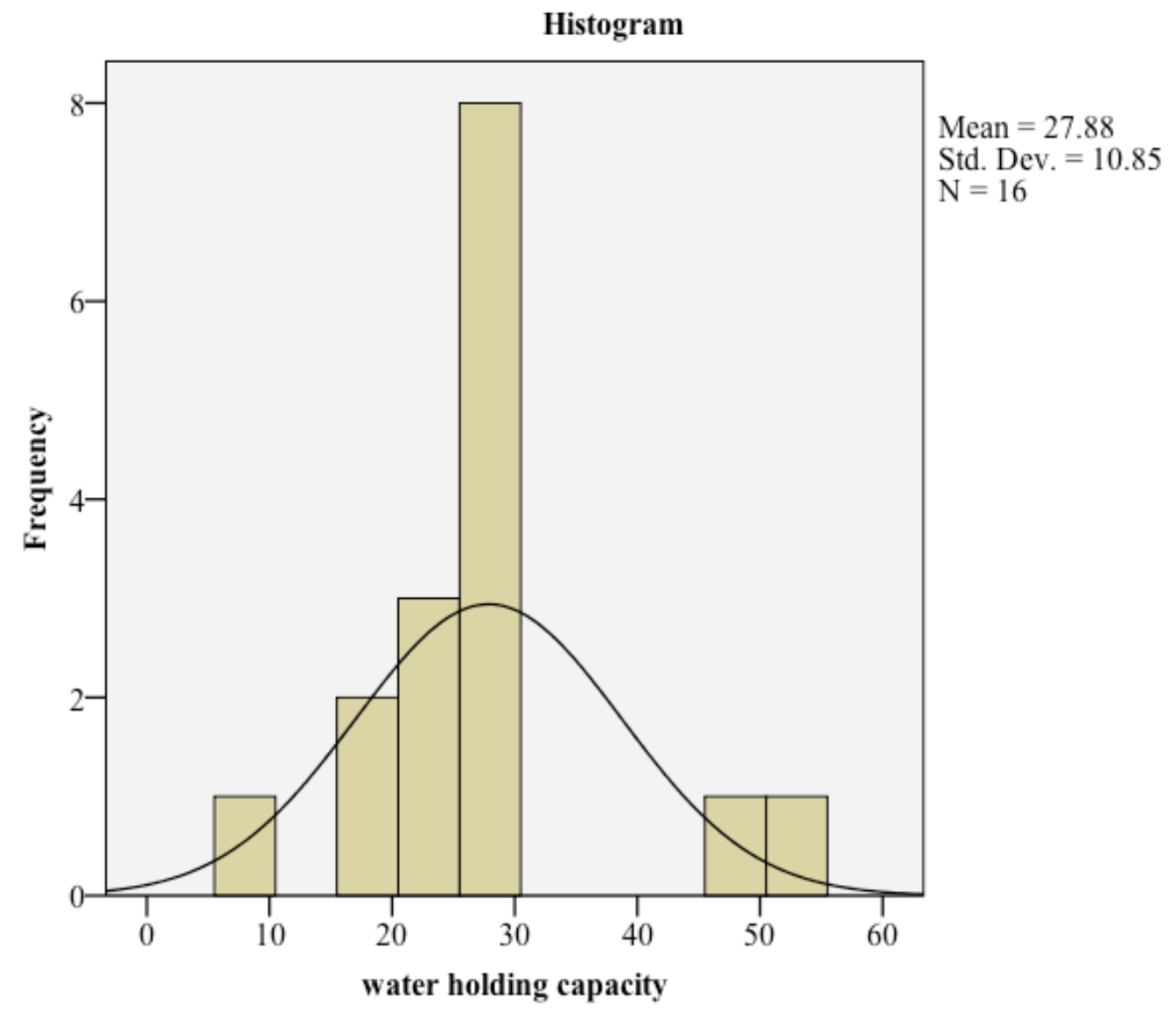

Figure 14. Water-holding capacity histogram with normality distribution curve. $($ Mean $=27.88$, Standard Deviation $=10.85, \mathrm{~N}=16)$ 


\section{Individual Plot Descriptions - Structural Characteristics}

\section{Extreme pygmy stratum.}

Big $\boldsymbol{L}(\boldsymbol{B L})$. This plot was located in the stratum classified as extreme pygmy by Russell and Woolhouse (2012). The total area occupied by the stems was approximately $4.86 \mathrm{~m}^{2}$. Stems were growing very tightly together, making it difficult to identify where the root bole originated or if there was in fact a root bole (Figures 15 and 16). The organic layer was an average of $12.7 \mathrm{~cm}$ deep. A total of 338 stems were counted; 33 had dead tops. Due to the high number of stems, a size class was developed (Table 16) in which four stems were taller than $1.83 \mathrm{~m}$. Fire marks were not observed.

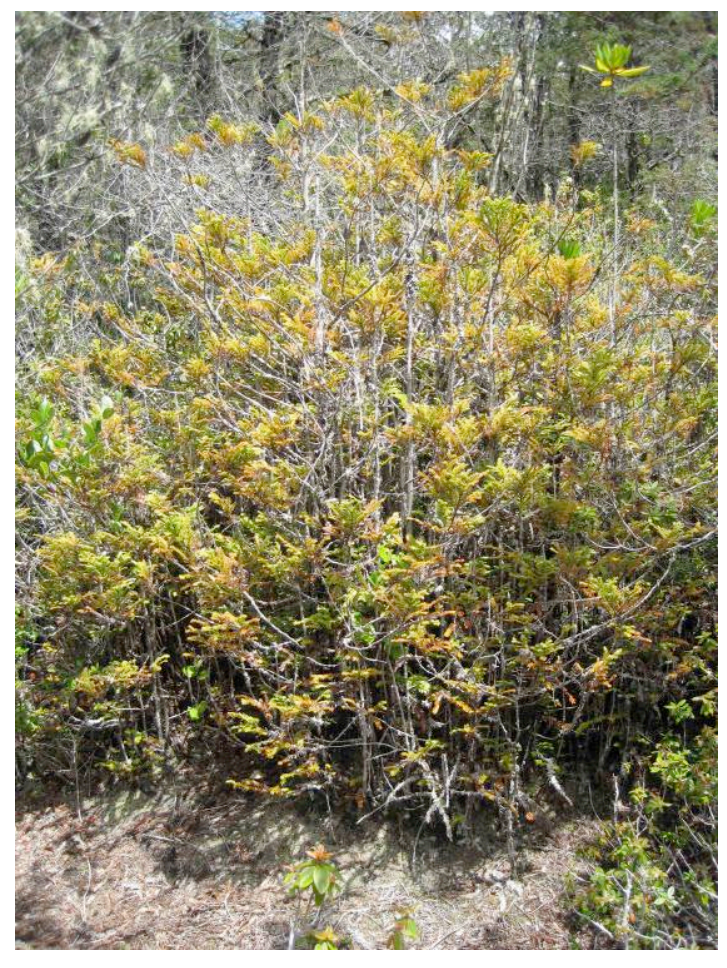

Figure 15. Big L growth form.

It had 338 stems tightly clustered together growing in an approximate space of $4.86 \mathrm{~m}^{2}$ in the extreme pygmy stratum. 


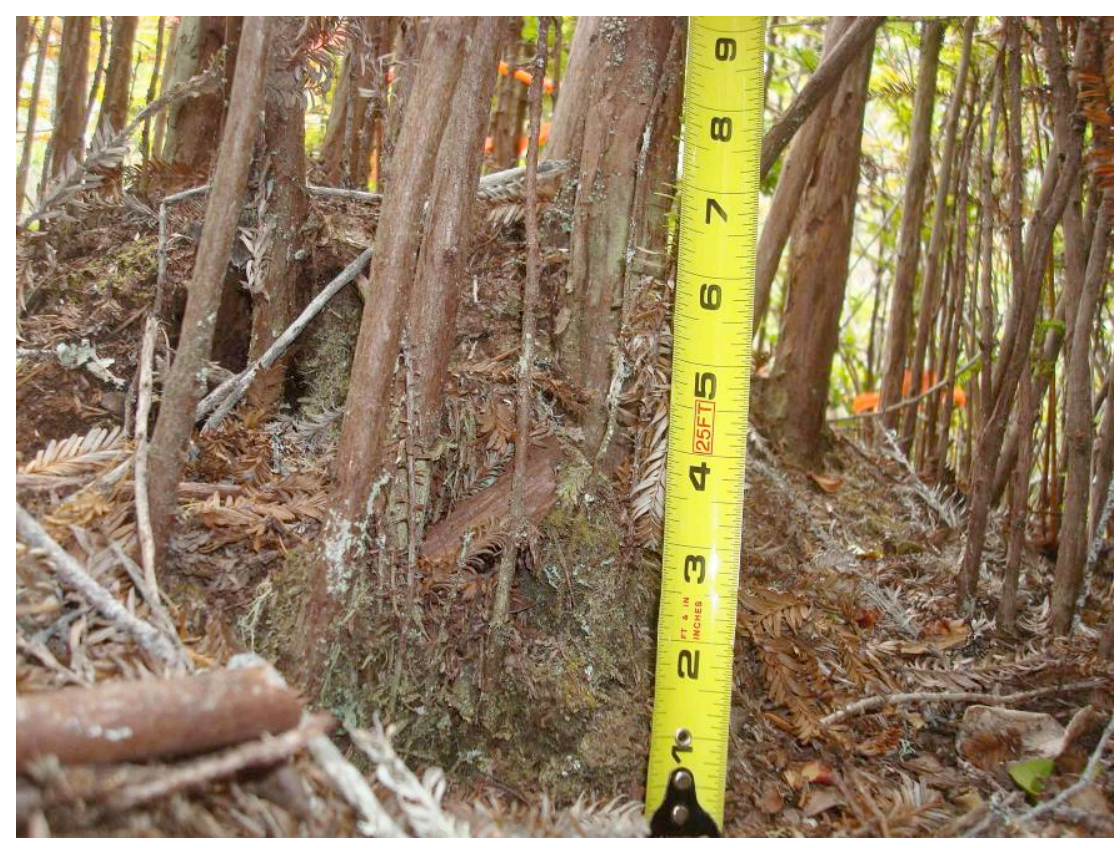

Figure 16. Big L stems in the extreme pygmy stratum with organic layer to scale. Note the measuring tape is in inches.

Table 16

Big L stems in their respective height classes

\begin{tabular}{ccc}
\hline $\begin{array}{c}\text { Height Classes } \\
\text { (meters) }\end{array}$ & \# stems & Dead Stems \\
\hline $0-0.91$ & 272 & 1 \\
$>0.91-1.83$ & 62 & 17 \\
$>1.83$ & 4 & 15 \\
\hline
\end{tabular}

Note. 338 stems were counted

FG. Unlike plot BL, this plot had single stems coming out individually from the ground with a very thin organic layer. FG was a cluster of 16 stems occupying an area of approximately $4.86 \mathrm{~m}^{2}$. The tallest pole measured $2.03 \mathrm{~m}$, with a DBH at $14.99 \mathrm{~cm}$. Four of the poles had a DBH less than $1.27 \mathrm{~cm}$; therefore, their basal diameter was measured. Out of the 16 stems, five had dead tops. Two stems developed codominance, pole BR 
and seedling BO. One of BR codominant stems broke off at $0.46 \mathrm{~m}$, and the remaining stem had a dead top. BO's codominance had no signs of break, and both stems were alive (Figure 17). Sapling JW had two lateral branches longer than its height that measured approximately $1.3 \mathrm{~m}$ long. Pole PT also had a long lateral branch measuring half its total height, $1.19 \mathrm{~m}$ long (Table 17). Furthermore, a majority of the trees had developed mature bark (Figure 18). Fire marks were not observed within the plot.

Table 17

Structural characteristics of 16 stems within the FG plot

\begin{tabular}{|c|c|c|c|c|}
\hline Tree & $\begin{array}{l}\text { Height } \\
\text { (m) }\end{array}$ & $\begin{array}{l}\mathrm{DBH} \\
(\mathrm{cm})\end{array}$ & $\begin{array}{c}\text { Basal } \\
\text { Diameter } \\
(\mathrm{cm})\end{array}$ & $\begin{array}{c}\text { Dead } \\
\text { Top }\end{array}$ \\
\hline $\mathrm{MG}$ & 1.6 & & $2.03 *$ & No \\
\hline $\mathrm{TM}$ & 0.76 & & $2.03^{* \wedge}$ & No \\
\hline $\mathrm{CO}$ & 1.45 & & $2.54 *$ & Yes \\
\hline MW & 1.68 & & $3.05^{*}$ & No \\
\hline JW & 1.24 & & $1.78^{* \wedge}$ & No \\
\hline SW & 1.75 & 2.29 & 5.59 & No \\
\hline $\mathrm{PT}$ & 2.49 & 14.99 & 17.78 & No \\
\hline BR & 2.03 & 2.29 & 17.78 & Yes \\
\hline $\mathrm{JO}$ & 0.48 & & $1.02^{\wedge *}$ & Yes \\
\hline $\mathrm{AC}$ & 1.40 & 1.78 & & No \\
\hline QG & 1.27 & & $1.78^{\wedge}$ & No \\
\hline $\mathrm{CL}$ & 1.14 & & $1.52^{\wedge}$ & No \\
\hline $\mathrm{CS}$ & 1.17 & & $2.03^{\wedge}$ & No \\
\hline $\mathrm{BO}$ & 1.22 & & $2.03^{\wedge}$ & No \\
\hline LS & 1.6 & 2.03 & 5.08 & Yes \\
\hline MP & 1.57 & & $7.11^{\wedge}$ & Yes \\
\hline
\end{tabular}




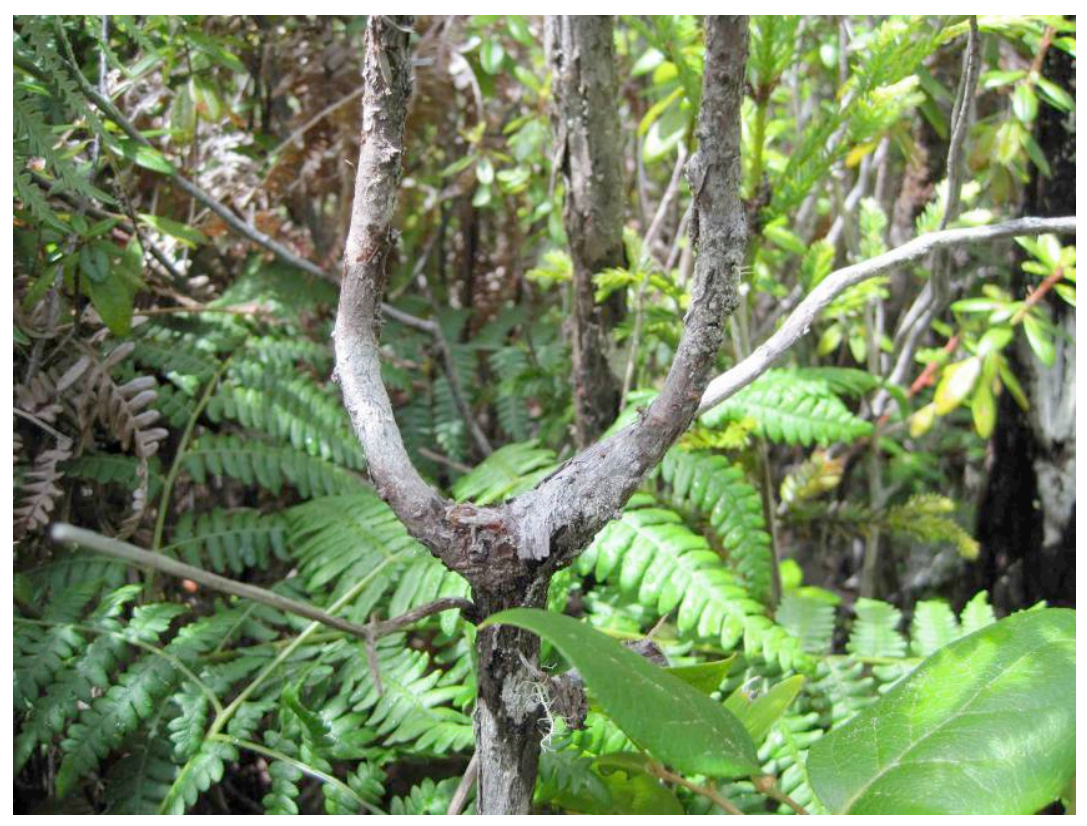

Figure 17. Seedling BO structural growth form within the FG plot in the extreme pygmy stratum.

There is no sign of break where two codominant stems originate.

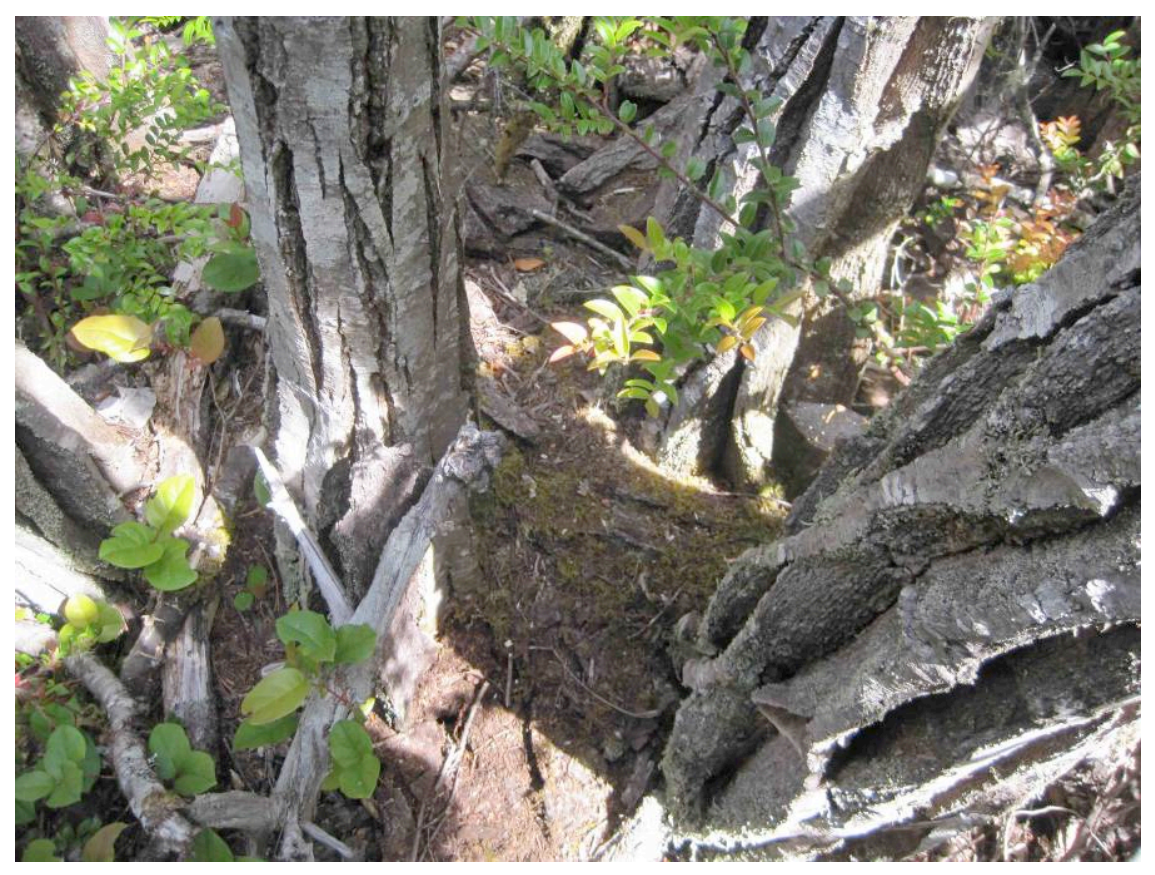

Figure 18. Base of FG cluster.

$\mathrm{BR}$ is on the bottom right corner displaying signs of mature bark. 
$\boldsymbol{A B C}$. It had a total of 37 stems occupying an area approximately $7.09 \mathrm{~m}^{2}$ (Figure 19). Out of the $37 \mathrm{stems}, 20$ had dead tops, including one seedling measuring $6.35 \mathrm{~cm}$ in height (Table 18). The tallest tree measured $2.29 \mathrm{~m}$, dead top included. The growth pattern shared characteristics with both BL and FG plots. The stems were small and resembled sprouts more than single trees (Figure 20). In contrast to BL, they were spread out, rather than being in a tight cluster. Also, within the plot there were a total of 11 dead stems. It was difficult to verify if each stem shared the same root system from an old tree, or if they were separate individual stems, a DNA test would be required to determine if the stems are in fact clonal. Nevertheless, a rough diagram was created to illustrate the location of each stem. Two measuring tapes were placed along the boundary of the plot to create coordinate points for each stem (Figure 19). In the northwest section of the plot, there was a decomposing rhododendron where at least seven of the stems originated, A through F. Fire marks were not present. Adjacent to the plot, $5 \mathrm{~m}$ Northwest, there is an apparent significant change in vegetation diversity and height. Following the Russell and Woolhouse (2012) strata identification, the vegetation jumps from extreme pygmy stratum to the tall pygmy. 
Table 18

ABC stems structural characteristics in the extreme pygmy stratum

\begin{tabular}{|c|c|c|c|c|}
\hline Tree & Total Height (m) & DBH (cm) & $\begin{array}{c}\text { Basal } \\
\text { Diameter }(\mathrm{cm})\end{array}$ & Dead Top \\
\hline A & 1.9 & 1.27 & & no \\
\hline B & 1.6 & 1.02 & & yes \\
\hline $\mathrm{C}$ & 1.68 & 0 & $2.03 *$ & yes \\
\hline $\mathrm{D}$ & 0.61 & 0 & $2.03^{\wedge}$ & no \\
\hline E & 0.15 & 0 & $2.03^{\wedge}$ & yes \\
\hline $\mathrm{F}$ & 0.86 & 0 & $2.03^{\wedge}$ & yes \\
\hline G & 1.4 & 0 & $3.81^{*}$ & yes \\
\hline $\mathrm{H}$ & 2.29 & 0 & $4.32 *$ & yes \\
\hline I & 1.63 & 0 & $2.29 *$ & yes \\
\hline $\mathrm{J}$ & 1.6 & 0 & $3.05^{*}$ & yes \\
\hline K & 0.41 & 0 & $1.52^{\wedge}$ & yes \\
\hline L & 1.19 & 0 & $6.60^{\wedge}$ & yes \\
\hline M & 1.4 & 3.81 & & yes \\
\hline $\mathrm{N}$ & 0.41 & 0 & $<1.27^{\wedge}$ & no \\
\hline $\mathrm{O}$ & 0.42 & 0 & $<1.27^{\wedge}$ & yes \\
\hline Cutie & 0.06 & 0 & & yes \\
\hline $\mathrm{P}$ & 0.2 & 0 & $<1.27^{\wedge}$ & no \\
\hline Q & 0.02 & 0 & $<1.27^{\wedge}$ & no \\
\hline $\mathrm{R}$ & 0.44 & 0 & $3.81^{\wedge}$ & yes \\
\hline S & 0.34 & 0 & $<1.27^{\wedge}$ & no \\
\hline $\mathrm{T}$ & 0.83 & 0 & $1.91^{\wedge}$ & yes \\
\hline $\mathrm{U}$ & 1.65 & 0 & $3.81^{*}$ & no \\
\hline V & 1.3 & 0 & $3.81 *$ & yes \\
\hline W & 1.65 & 0 & $<1.27^{*}$ & no \\
\hline$X$ & 1.08 & 0 & $1.27^{\wedge}$ & yes \\
\hline Y & 1.56 & 0 & $<1.27^{*}$ & no \\
\hline Z & 1.17 & 0 & $1.27^{\wedge}$ & no \\
\hline $\mathrm{AA}$ & 0.94 & 0 & $<1.27^{\wedge}$ & yes \\
\hline $\mathrm{AB}$ & 0.79 & 0 & $<1.27^{\wedge}$ & no \\
\hline $\mathrm{AC}$ & 0.32 & 0 & $<1.27^{\wedge}$ & no \\
\hline $\mathrm{AD}$ & 0.3 & 0 & $<1.27^{\wedge}$ & no \\
\hline $\mathrm{AE}$ & 0.39 & 0 & $1.27^{\wedge}$ & no \\
\hline $\mathrm{AF}$ & 0.75 & 0 & $1.91^{\wedge}$ & no \\
\hline $\mathrm{AG}$ & 0.84 & 0 & $<1.27^{\wedge}$ & yes \\
\hline $\mathrm{AH}$ & 0.84 & 0 & $<1.27^{\wedge}$ & yes \\
\hline
\end{tabular}


Table 18 (continued)

\begin{tabular}{ccccc} 
Tree & Total Height $(\mathrm{m})$ & DBH $(\mathrm{cm})$ & Basal & \\
AI & 0.31 & 0 & $3.81^{\wedge}$ & Dead Top \\
AJ & 0.97 & 0 & $1.27^{\wedge}$ & no \\
\hline
\end{tabular}

Note. Structural characteristics of 37 stems growing within the extreme pygmy stratum.

$\wedge=$ Height is $<1.37 \mathrm{~m}$

$*=\mathrm{DBH}$ is $<1.27 \mathrm{~cm}$

Basal diameter was measured when DBH was less than $1.27 \mathrm{~cm}$, and/or total stem height was less than $1.37 \mathrm{~m}$. Unable to measure basal diameter of Cutie.

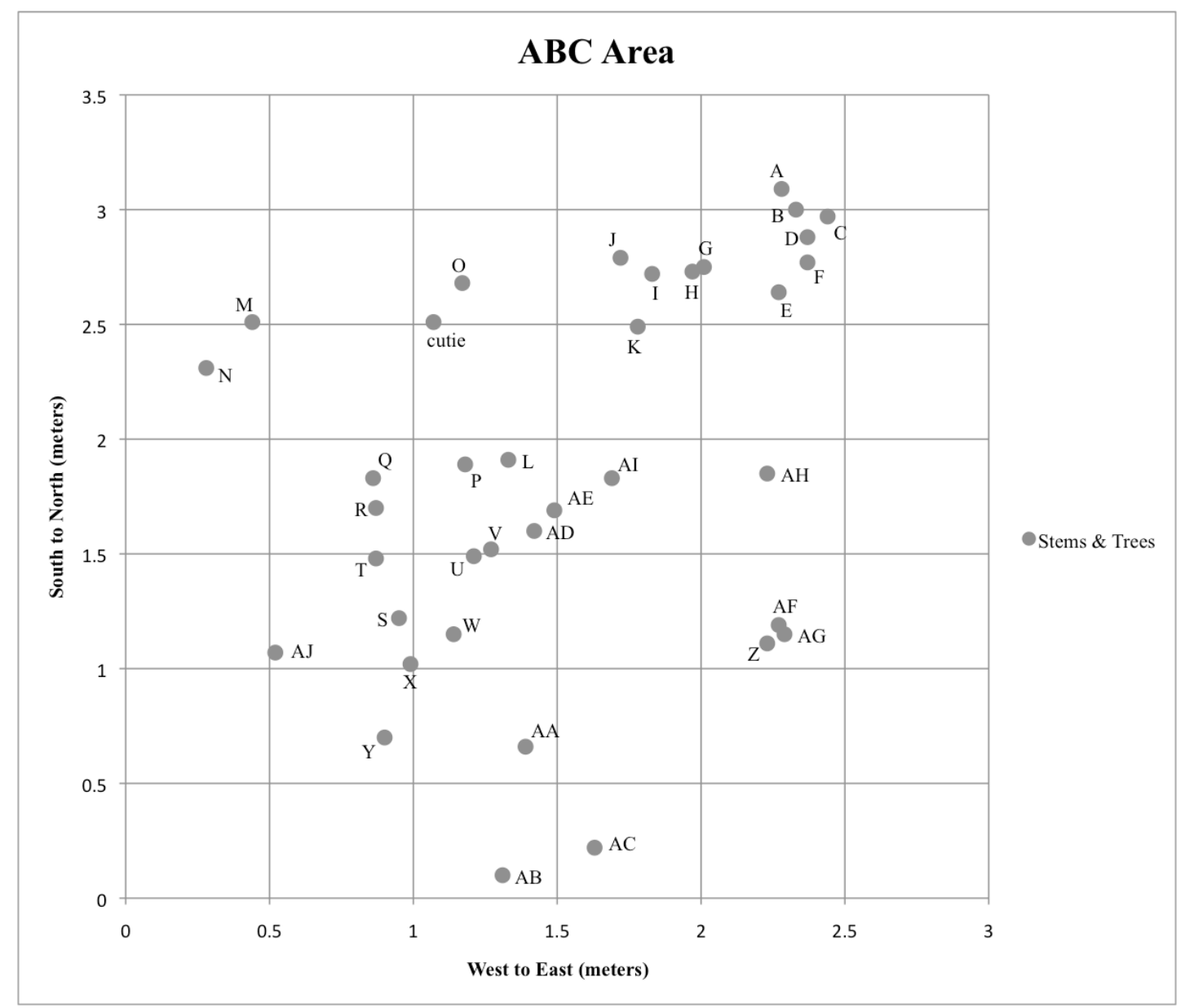

Figure 19. Stem map for the $\mathrm{ABC}$ cluster in the extreme pygmy stratum. Points below $1.4 \mathrm{~m}$ on the south to north axis were trees and stems in a dense Huckleberry shrub. 


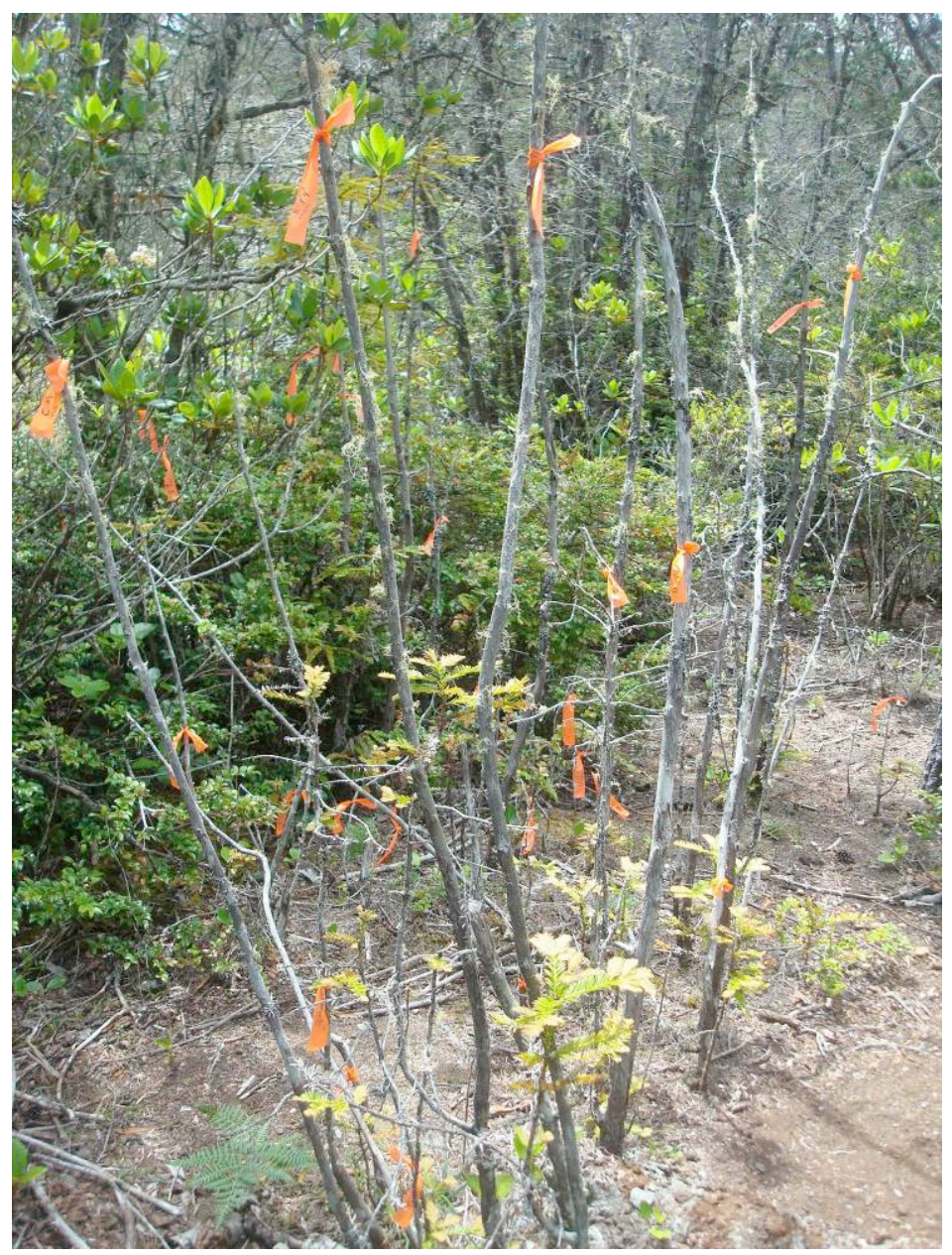

Figure 20. ABC plot growth form.

These stems are in the northeast section of the ABC plot, growing within a decomposing Rhododendron stump. They include stems A through J (Figure 19).

\section{Short pygmy stratum.}

Vagabond (VB). This plot was composed of a single tree with two stems

originating at the base. Its total height was $9.2 \mathrm{~m}$, with a DHB of $16.26 \mathrm{~cm}$. The smaller stem had a DBH of $6.1 \mathrm{~cm}$, and it split from main trunk at $41 \mathrm{~cm}$ from true ground. The duff layer measured $13 \mathrm{~cm}$. VB's main trunk was significantly exposed (Figure 21). Foliage was present at the end of its lateral branches. Younger needles were a lush green, 
whereas older needles were brown and appeared desiccated. Furthermore, the tree did not have sprouts originating at the base. It did, however, have a dead stem between the two live stems. Fire marks, reiterations, and epiphytes were not observed on the tree.

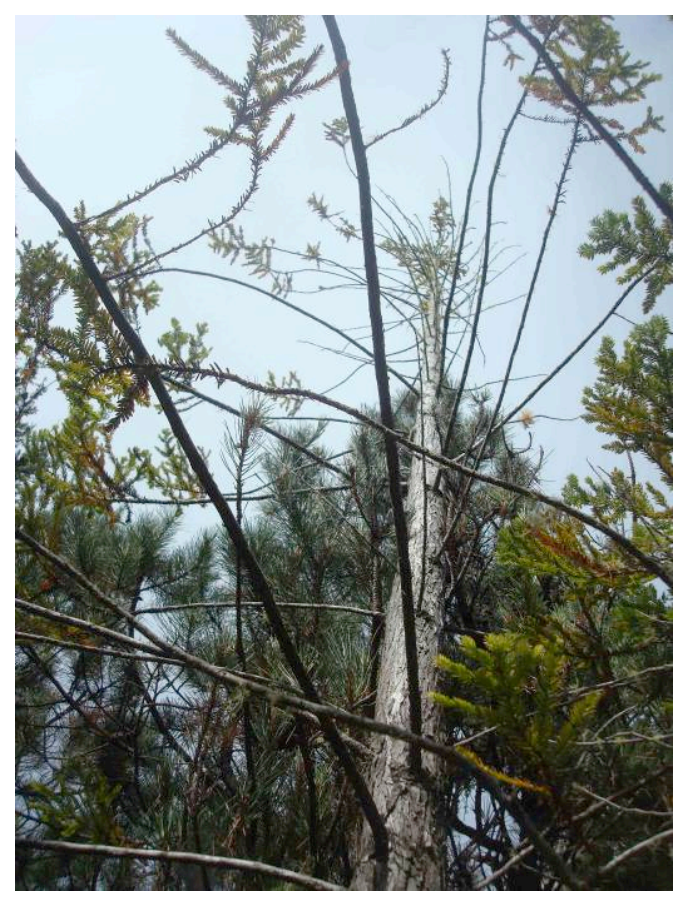

Figure 21. Vagabond plot in the short pygmy stratum.

Single pole canopy structure and bare trunk. Leaves were only present at the end of the branches.

Sibling Rivalry (SIR). This plot occupied an approximate area of $0.99 \mathrm{~m}^{2}$. There were a total of 11 stems, with poles and saplings originating at the base of a burl (Figure 22). The organic layer measured an average of $13.6 \mathrm{~cm}$. The tallest pole measured was $5.2 \mathrm{~m}$ tall with a DBH of $22.1 \mathrm{~cm}$ (Table 19). It had four stems at the base with a significant number of clonal sprouts. Saplings H and I (Figure 22) grew horizontally out from the burl then straight up, probably due to accessibility to light. Moreover, the younger needles had the appearance of "sun leaves" and closely resembled needles of 
giant sequoia (Sequoiadendron giganteum), in that they were short, stiff, crowded, and overlapping. The shoots originating from the lateral branches were consistently pointing straight up, resembling epicormic sprouts (Figure 23). Reiterations and epiphytes were not observed. Fire marks were not observed.

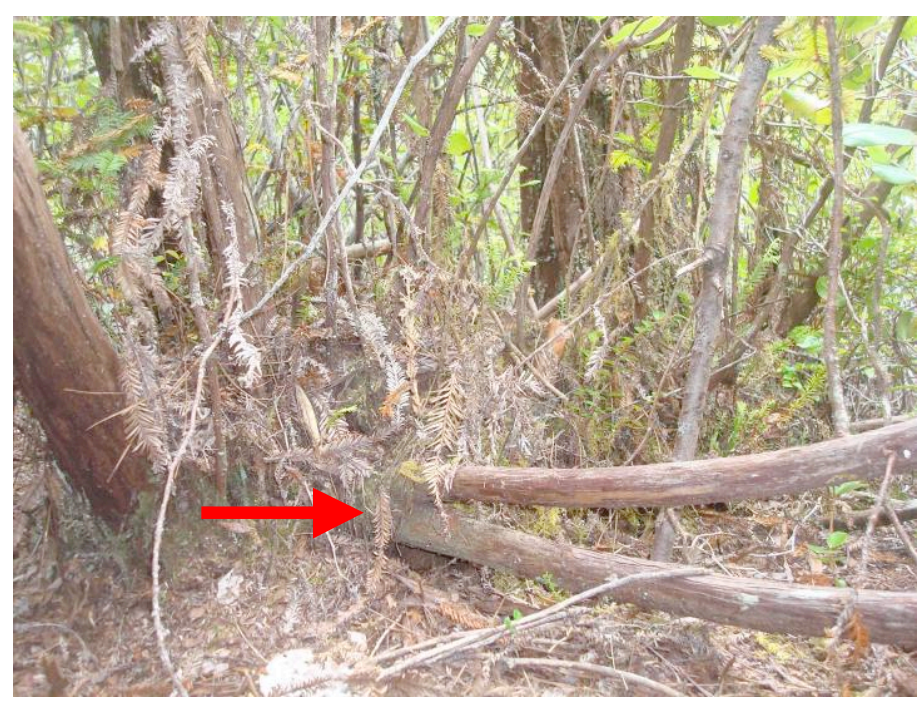

Figure 22. Sibling Rivalry burl in the short pygmy stratum.

Saplings $\mathrm{H}$ and I growing horizontally out of the burl, and then becoming vertical. Organic layer measured $14 \mathrm{~cm}$. 


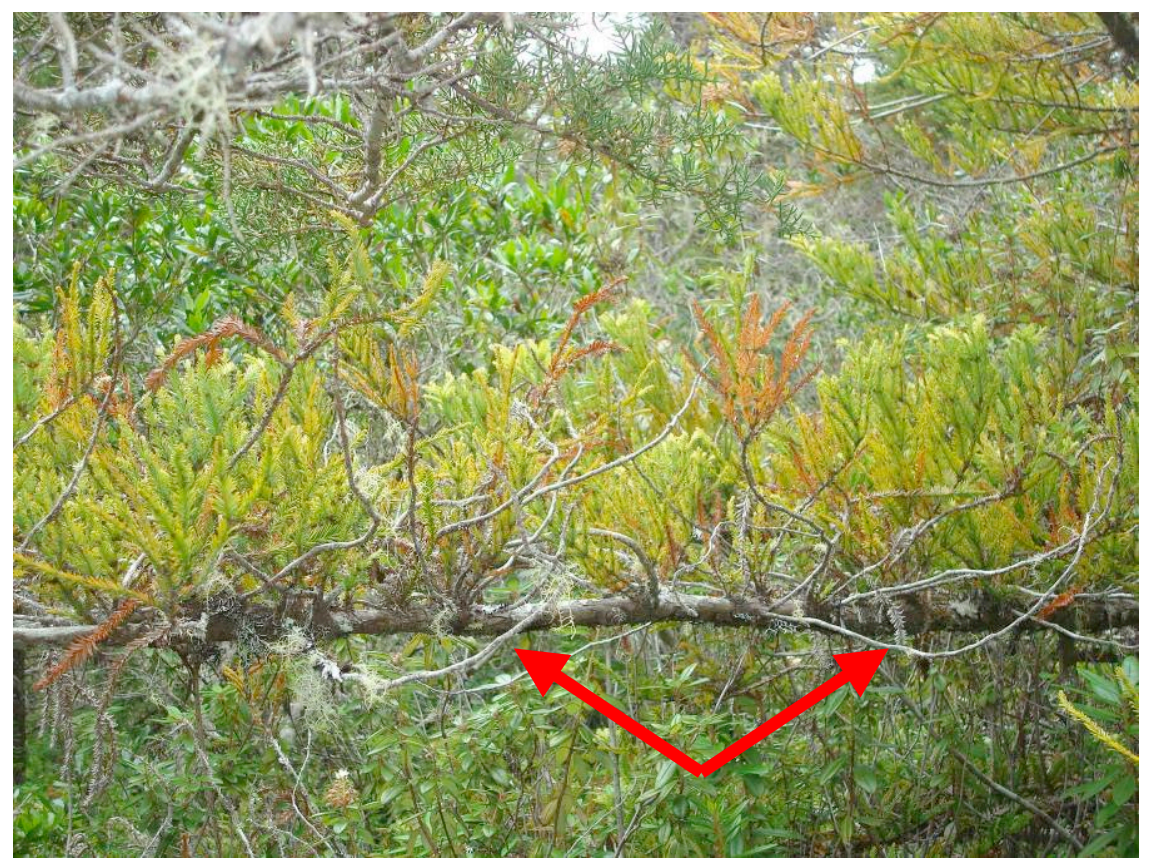

Figure 23. Sibling Rivalry canopy structure.

All shoots originating from the lateral branches are vertical. Horizontal shoots were not observed on this plot within the short pygmy stratum.

\section{Table 19}

Sibling Rivalry stems structural characteristics

\begin{tabular}{|c|c|c|c|}
\hline Tree & $\begin{array}{c}\text { Total } \\
\text { Height (m) }\end{array}$ & $\begin{array}{l}\mathrm{DBH} \\
(\mathrm{cm})\end{array}$ & Dead Top \\
\hline $\mathrm{A}$ & 5.2 & 22.1 & Yes \\
\hline B & 3.5 & 11.43 & Yes \\
\hline $\mathrm{C}$ & 2.8 & 4.83 & Yes \\
\hline D & 2.8 & 3.3 & No \\
\hline E & 2.8 & 2.79 & Yes \\
\hline $\mathrm{F}$ & 2 & 1.27 & Yes \\
\hline G & 2.2 & 2.79 & Yes \\
\hline $\mathrm{H}$ & 2.1 & 1.52 & No \\
\hline I & 1.9 & 1.9 & No \\
\hline $\mathrm{J}$ & 1.7 & 0.76 & No \\
\hline K & 1.7 & 0.76 & Yes \\
\hline
\end{tabular}

Note. A total of two poles and nine saplings. Basal diameter was not measured due to the thickness of the organic layer. 
YG. This plot was located between the short and tall pygmy strata (Russell \& Woolhouse, 2012). It occupied an approximate area of $19.58 \mathrm{~m}^{2}$. There were a total of four trees within the plot. The tallest tree, YO, measured $7.4 \mathrm{~m}$ in height, and had a DBH of $58 \mathrm{~cm}$. It shared old-growth characteristics with trees described by Sillett and Van Pelt (2000a, 2000b), though on a significantly smaller scale. YO had two major reiterations above $5 \mathrm{~m}$ into the canopy below the area where the tree lost its top. It also had a mature two-stem huckleberry (Vaccinium ovatum) (Table 20). It was established in an area where the tree lost its original top and was in decay. Six reiterations were observed with a basal diameter of less than $12.7 \mathrm{~cm}$. The canopy structure of trees Chuy $(\mathrm{CH})$, Hans (HS) and R2 was not as complex as YO's (Tables 20 and 21). R2 halted its vertical growth and continued its growth laterally (Figure 24) resembling that of the main rotor blades of a helicopter. A sprout was observed on R2 where the lateral growth began. At $2.3 \mathrm{~m}$, Hans main trunk had a significant bend. This could have been the result of a broken top when the tree was much smaller, or the tree's shift in growth due to a necessity for sunlight (Figure 25). In addition, fire marks were present on the main trunk and halted where the bend originated. Epiphytes were not observed on Chuy, Hans, or R2. The basal diameter of the lateral branches for all three trees was approximately less than $7.62 \mathrm{~cm}$. Fire marks were observed in all four trees, except $Y O$ had fire marks only at the base. 
Table 20

YO canopy complexity at the edge of the short and tall pygmy strata

\begin{tabular}{ccccc}
\hline $\begin{array}{c}\text { Hierarchy } \\
\text { rank }\end{array}$ & $\begin{array}{c}\text { Height from } \\
\text { ground }(\mathrm{m})\end{array}$ & $\begin{array}{c}\text { Basal Diameter } \\
\text { off trunk }(\mathrm{cm})\end{array}$ & $\begin{array}{c}\text { Total } \\
\text { epiphytes }\end{array}$ & Species \\
\hline BRT & 5.3 & 24.89 & 0 & \\
BRT & 5.4 & 18.54 & 0 & \\
BT & 5.3 & $<12.7$ & 0 & \\
T & 5.3 & 0 & 1 & Vaov \\
\hline
\end{tabular}

Note. Vaov: Vaccinium ovatum 'Huckleberry'

Tree's total height was $7.4 \mathrm{~m}$ and DBH was $58 \mathrm{~cm}$.

Table 21

Chuy, Hans, and R2 structural characteristics within the YG plot

\begin{tabular}{ccc}
\hline Tree & Height $(\mathrm{m})$ & DBH $(\mathrm{cm})$ \\
\hline CH & 1.65 & 25.15 \\
HS & 5.6 & 25.91 \\
R2 & 4.4 & 17.53 \\
\hline
\end{tabular}

Note. Reiterations and epiphytes were not present in the canopy. All tops of poles were alive.

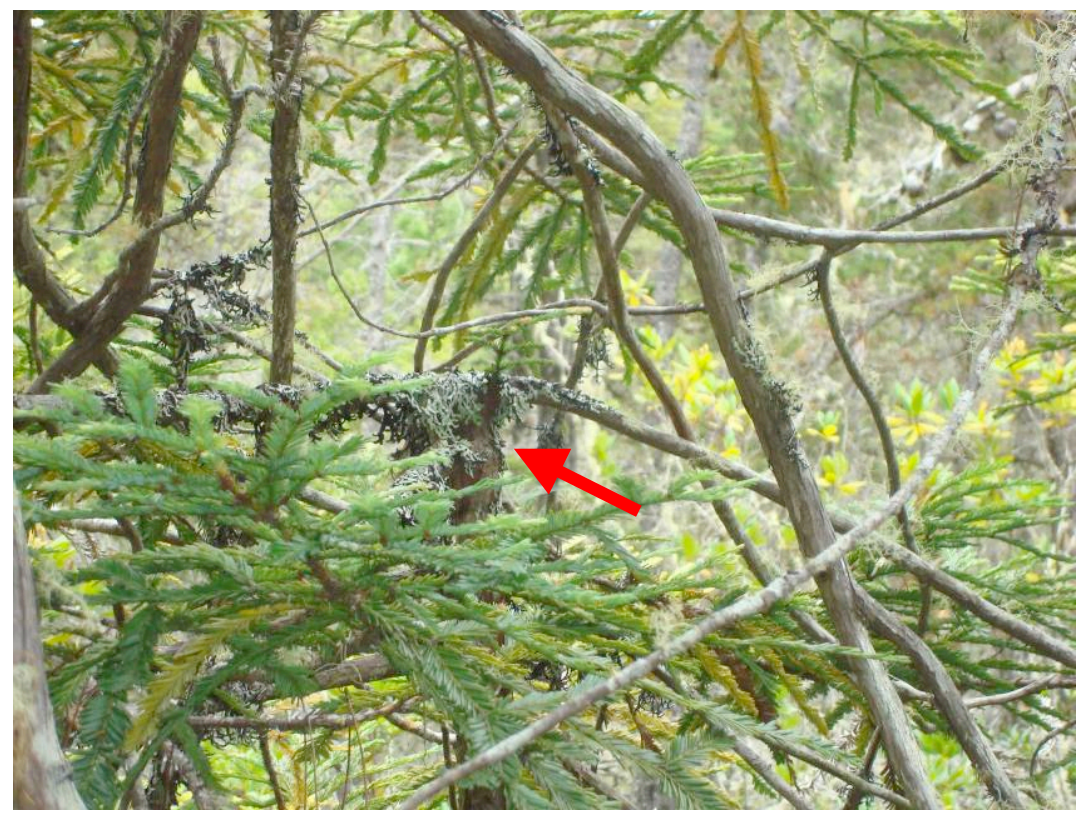

Figure 24. R2 in YG plot.

Its vertical growth halted, with small sprout at its maximum height (arrow). 


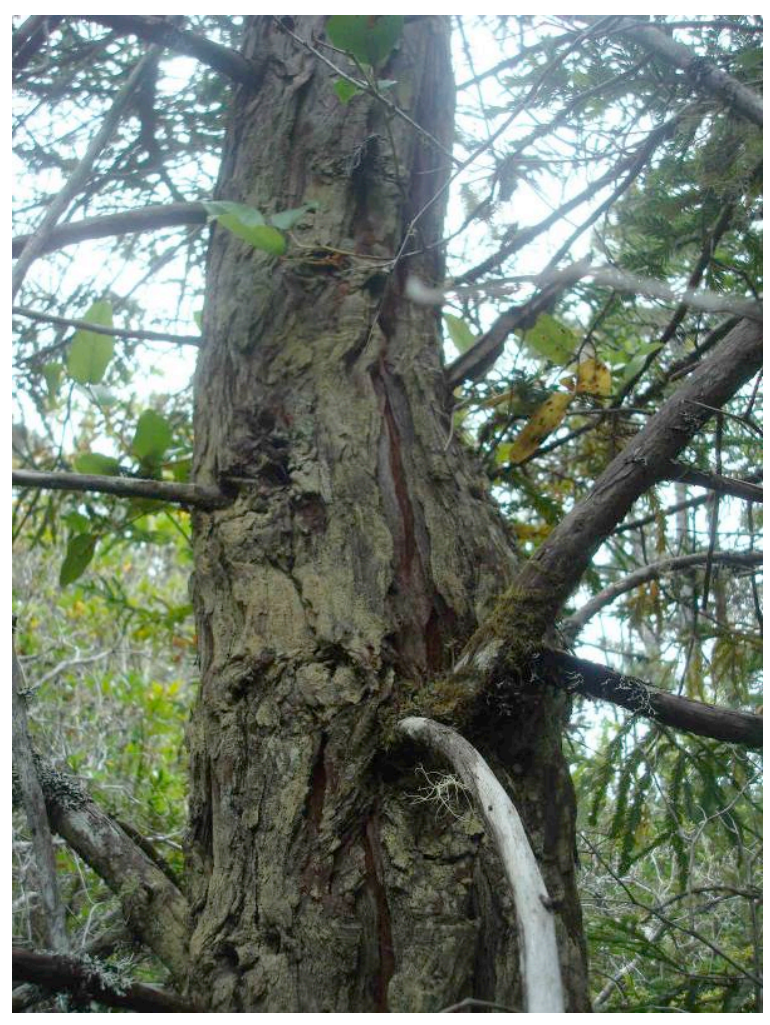

Figure 25. Hans in YG plot.

Structural bend of the trunk at $2.3 \mathrm{~m}$.

\section{Tall pygmy stratum.}

McKenna Grove (MG). This plot was located on an ecotone where vegetation measured between $3.5 \mathrm{~m}$ and $18 \mathrm{~m}$, and forest composition began to shift to conifers. Russell and Woolhouse (2012) classified this stratum as tall pygmy. A total of 124 stems were counted and placed into height classes (Table 22). The plot measured approximately $20.6 \mathrm{~m}^{2}$. The largest tree had a maximum DBH of $34 \mathrm{~cm}$ and had a total height of $8.8 \mathrm{~m}$. Canopy was accessed using an extension ladder. Reiterations were not present. Also, dead tops were observed only in the shorter stems (Table 22). On the south section of the plot, a dead Bishop pine fell on the plot creating an opening to the 
forest floor, which is where most of the seedlings were counted. Fire hollows or marks were not present in any of the trees.

Table 22

McKenna Grove stems in respective height classes within the tall pygmy stratum

\begin{tabular}{ccc}
\hline $\begin{array}{c}\text { Height Classes } \\
(\mathrm{m})\end{array}$ & $\begin{array}{c}\text { \# of } \\
\text { Stems }\end{array}$ & $\begin{array}{c}\text { Dead } \\
\text { Tops }\end{array}$ \\
\hline $0-0.91$ & 52 & 0 \\
$>0.91-1.83$ & 21 & 1 \\
$>1.83-2.74$ & 22 & 3 \\
$>2.74-3.66$ & 14 & 0 \\
$>3.66-4.57$ & 4 & 0 \\
$>4.57-5.49$ & 4 & 0 \\
$>5.49-6.4$ & 0 & 0 \\
$>6.4-7.32$ & 0 & 0 \\
$>7.32-8.21$ & 2 & 0 \\
$>8.21-9.14$ & 3 & 0 \\
$>9.14-10.06$ & 2 & 0 \\
$>10.06-10.97$ & 0 & 0 \\
\hline Note. A total of 124 in the McKenna Grove, within the tall pygmy stratum, and placed into twelve height \\
classes, most of which were seedlings.
\end{tabular}

Hogs Grove (HG). This plot had 91 stems (Table 23), and occupied approximately $32.09 \mathrm{~m}^{2}$. The maximum height measured was $10.85 \mathrm{~m}$, with a DBH of $34 \mathrm{~cm}$. Reiterations were not observed, nor were fire marks. Salal (Gaultheria shallon) was recorded growing out of the trunk of a tree, $38 \mathrm{~cm}$ above ground as an epiphyte. The plant was growing directly from the bark where arboreal soil cannot accumulate (Figure 26). Decay was not observed where the epiphyte was established. Furthermore, a number of the smaller trees, between $0.91 \mathrm{~m}$ and $3.66 \mathrm{~m}$ in height, shared similar structures to the ones observed in the YG plot, where the tree halted its vertical growth 
and growth continued laterally. The excurrent branching expected from saplings and poles was not observed in the plot.

Table 23

Hogs Grove stems in respective height classes within the tall pygmy stratum

\begin{tabular}{ccc}
\hline $\begin{array}{c}\text { Height Classes } \\
(\mathrm{m})\end{array}$ & $\begin{array}{c}\text { \# of stems \& } \\
\text { trees }\end{array}$ & $\begin{array}{c}\text { Dead } \\
\text { Tops }\end{array}$ \\
\hline $0-0.91$ & 4 & 0 \\
$>0.91-1.83$ & 17 & 0 \\
$>1.83-2.74$ & 25 & 4 \\
$>2.74-3.66$ & 15 & 2 \\
$>3.66-4.57$ & 8 & 0 \\
$>4.57-5.49$ & 11 & 0 \\
$>5.49-6.4$ & 2 & 0 \\
$>6.4-7.32$ & 0 & 0 \\
$>7.32-8.21$ & 6 & 0 \\
$>8.21-9.14$ & 1 & 0 \\
$>9.14-10.06$ & 0 & 0 \\
$>10.06-10.97$ & 2 & 0 \\
\hline
\end{tabular}

Note. Total of 91 stems. 


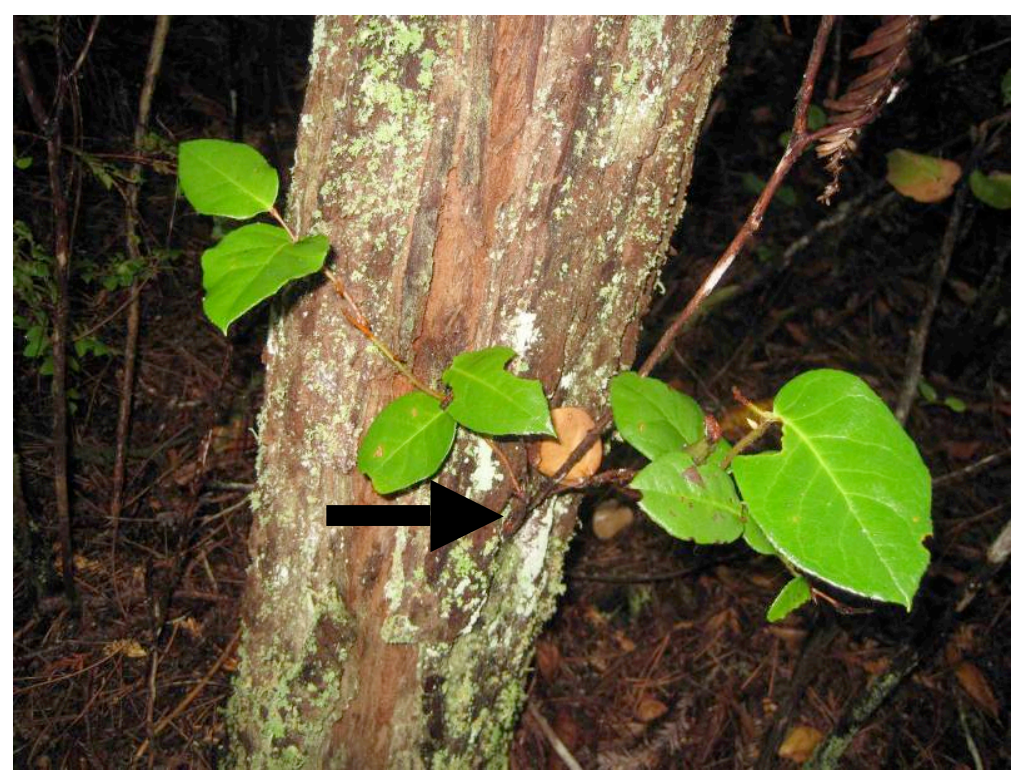

Figure 26. Epiphyte in Hogs Grove plot on main trunk within the tall pygmy stratum. Epiphytic vascular plant salal (Gaultheria shallon), growing from the bark of the main trunk. The tree measured a height between $7.32 \mathrm{~m}$ and $8.21 \mathrm{~m}$, and measured $14.37 \mathrm{~cm}$ at DBH.

Santa Barbara (SB). This plot occupied an area of approximately $18.18 \mathrm{~m}^{2}$ and had a total of 99 stems (table 24). Fire marks were not observed, nor were reiterations. However, similar growth structures described in HG were also present in this grove; excurrent growth was not common within three of the shorter age classes. A number of the stems had what appeared to be small reiterations (Figure 27). The tallest sapling measured $5.89 \mathrm{~m}$ in height and had a DBH of $10 \mathrm{~cm}$. 
Table 24

Santa Barbara stems in respective height classes in the tall pygmy stratum

\begin{tabular}{ccc}
\hline height classes $(\mathrm{m})$ & \# of stems & Dead tops \\
\hline $0-.91$ & 12 & 7 \\
$>.91-1.83$ & 29 & 18 \\
$>1.83-2.74$ & 27 & 11 \\
$>2.74-3.66$ & 20 & 4 \\
$>3.66-4.57$ & 7 & 2 \\
$>4.57$ & 4 & 0 \\
\hline
\end{tabular}

Note. Total of 99 stems.
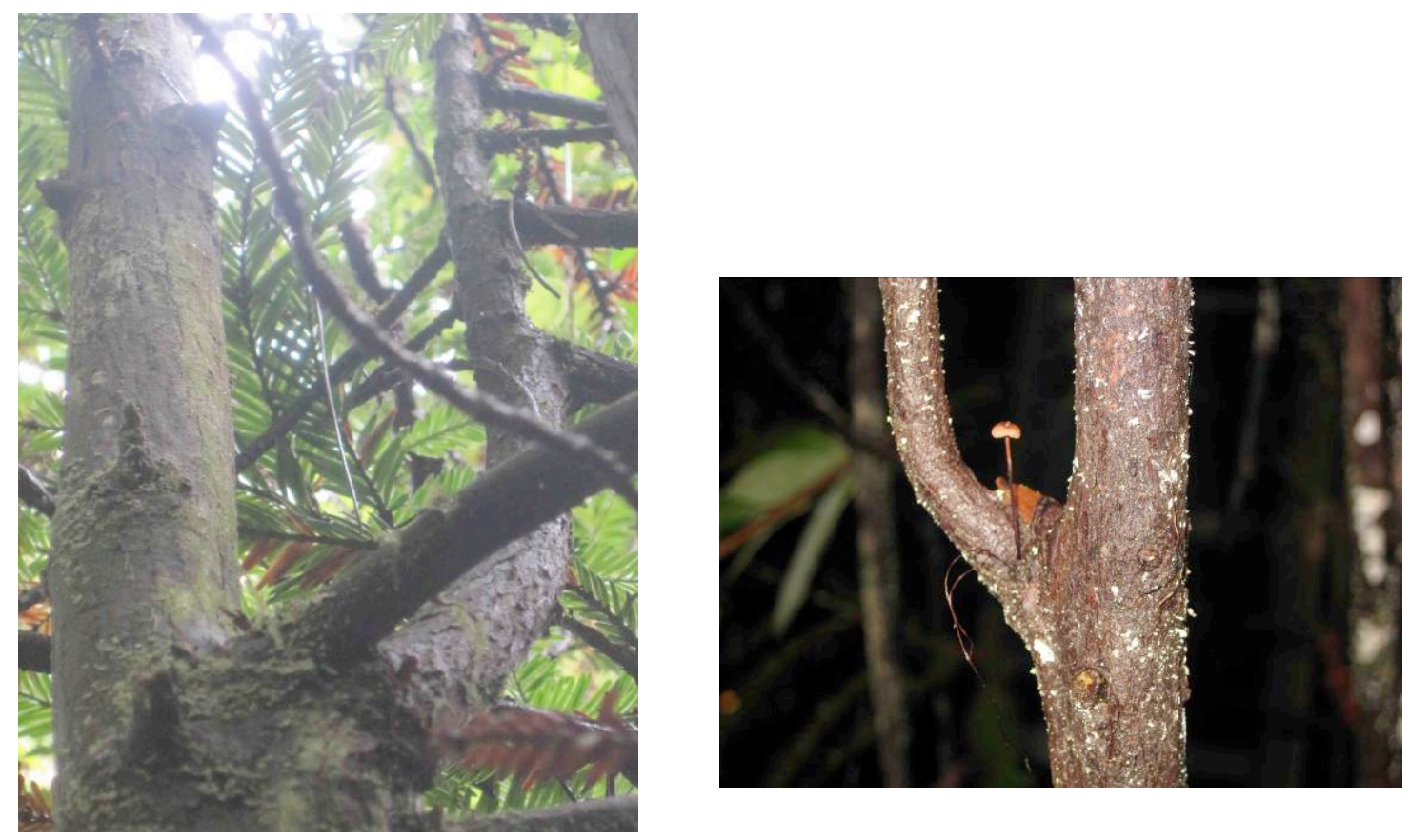

Figure 27. Santa Barbara stems' structural characteristics in the tall pygmy stratum. Branching did not follow excurrent growth. The branching pattern resembles small-scale reiterations.

Charles Grove (CG). Like the SB plot, this plot was at the ecotone of the tall pygmy and transitional stratum (Russell \& Woolhouse, 2012). There were a total of eighty-two stems in the plot, occupying an area of $18.7 \mathrm{~m}^{2}$ (Table 25). The tallest tree 
measured $12.1 \mathrm{~m}$ and had a DBH of $37.85 \mathrm{~cm}$. It had a reiteration at $3.32 \mathrm{~m}$; the point where fire marks stop. The original trunk broke off at approximately $2 \mathrm{~m}$ above the reiteration. Opposite to the main reiteration, there is a small reiteration with a basal diameter of $5.08 \mathrm{~cm}$. At $3.32 \mathrm{~m}$, there were five leather fern (Polypodium scouleri) established on the decaying trunk. The largest fern measured $27 \mathrm{~cm}$ in length and had seven pinnae. Arboreal soil was minimal, and was not measured, as disturbance would have resulted in permanent damage to the epiphytes.

Table 25

Charles Grove stems in respective height classes within the tall pygmy stratum

\begin{tabular}{ccc}
\hline Height Classes $(\mathrm{m})$ & \# of stems & Dead Tops \\
\hline $0-0.91$ & 12 & 0 \\
$>0.91-1.83$ & 4 & 0 \\
$>1.83-2.74$ & 7 & 3 \\
$>2.74-3.66$ & 18 & 2 \\
$>3.66-4.57$ & 14 & 3 \\
$>4.57-5.49$ & 6 & 1 \\
$>5.49-6.4$ & 5 & 0 \\
$>6.4$ & 16 & 0 \\
\hline
\end{tabular}

Note. Total of 82 stems.

\section{Transitional stratum.}

Russell Grove (RG). The plot was at the ecotone of the transitional and first redwood strata (Russell \& Woolhouse, 2012). It had three clonal stems, Louie, Skilly and 2-Will. Louie and 2-Will had fire hollows, whereas Skilly had fire marks. Louie's total height was $38.15 \mathrm{~m}$, followed by Skilly, $28.35 \mathrm{~m}$, and 2-Will approximately $20.45 \mathrm{~m}$. Although Louie was the tallest, Skilly had the largest DBH, $2.4 \mathrm{~m}$. Louie's DBH measured $1.76 \mathrm{~m}$, and 2-Will's measured $1.33 \mathrm{~m}$. At $25.95 \mathrm{~m}$ tall, Louie and Skilly's 
branches were intertwined. The woundwood caused by friction between branches was evidence of the strong winds the grove has endured in the past (Figure 28). At approximately $1.4 \mathrm{~m}$, from the ground, $3 \mathrm{~cm}$ above the parameter set for measuring $\mathrm{DBH}$, 2-Will split into two stems.

Louie had a fire hollow that measured $0.56 \mathrm{~m}^{3}$. Skilly did not have a fire hollow. 2-Will had a fire hollow in its stem that had a significant lean. The fire hollow's volume measured $1.21 \mathrm{~m}^{3}$. A single species of epiphytes was recorded on Louie, a leather fern, at $10.36 \mathrm{~m}$ from the ground. Epiphytes were not observed on Skilly. 2-Will had a single leather fern, it was established on a broken dead branch.

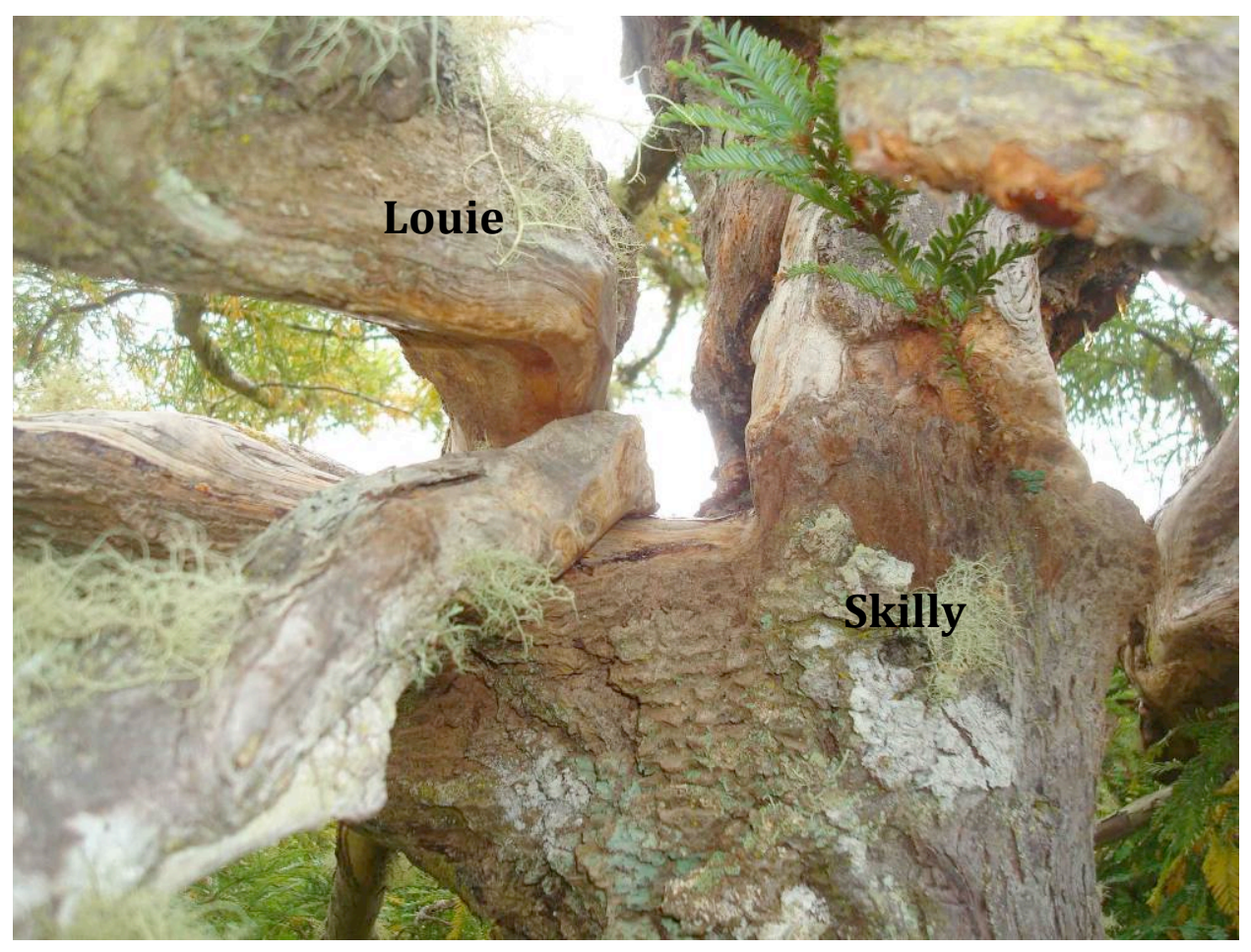

Figure 28. Russell Grove in the transitional stratum. Woundwood at $25.95 \mathrm{~m}$ from Skilly and Louie intertwined lateral branches. 
Louie's canopy was selected for structural characterization of the plot (Table 26). Unlike IN and EP, the top of Louie was alive. At $20.45 \mathrm{~m}$, Louie had two codominant stems. At the split each stem measured $48.26 \mathrm{~cm}$ and $43.18 \mathrm{~cm}$ in diameter.

Table 26

Louie hierarchical ranks within the Russell Grove in the transitional stratum

\begin{tabular}{ccccc}
\hline $\begin{array}{c}\text { Branch } \\
\text { Hierarchy }\end{array}$ & $\begin{array}{c}\text { Height from } \\
\text { ground }(\mathrm{m})\end{array}$ & $\begin{array}{c}\text { Basal } \\
\text { Diameter off } \\
\text { trunk }(\mathrm{cm})\end{array}$ & $\begin{array}{c}\text { Total } \\
\text { epiphytes }\end{array}$ & Species \\
\hline BT & 6.64 & 22.86 & 0 & 0 \\
BRRLT & 6.34 & 40.13 & 0 & 0 \\
BT & 10.45 & 13.21 & 0 & 0 \\
BRLT & 10.36 & 25.15 & 13 & Posc \\
BRLT & 10.36 & 19.56 & 0 & 0 \\
BT & 11.04 & 19.3 & 0 & 0 \\
BLT & 12.45 & 12.95 & 0 & 0 \\
BT & 10.60 & 21.61 & 0 & 0 \\
BRLLT & 11.07 & 34.29 & 0 & 0 \\
BRLT & 14.7 & 24.13 & 0 & 0 \\
BT & 14.9 & 19.81 & 0 & 0 \\
BRRLT & 14.9 & 56.13 & 0 & 0 \\
BRLT & 15.7 & 28.96 & 0 & 0 \\
BRLT & 17.05 & 25.65 & 0 & 0 \\
\hline Note. Epiphytes - Posc: Polypodium scouleri 'Leather Fern’
\end{tabular}

Umbrella Grove (UG). This plot was located north of the RG plot. A total of eight stems were within the boundaries of the plot, an area of approximately $54.06 \mathrm{~m}^{2}$. The structure of the trees in this plot had an umbrella shaped canopy (Figure 29). The tops had not been broken off, but the growth was somewhat decurrent (Figure 30). Out of the eight trees, only one had a fire hollow; tree A, measuring $0.48 \mathrm{~m}^{3}$. The rest had fire marks, with the exception of trees $\mathrm{G}$ and $\mathrm{H}$. The canopy of tree A was accessed with a $4.9 \mathrm{~m}$ extension ladder. Total height was $17 \mathrm{~m} \pm 1 \mathrm{~m}$; it was measured from climbing 
Louie in the RG plot. Total height for all the trees was not measured due to the nature of their structure. Tree A had 14 leather ferns, all of which were live fronds (Table 27).

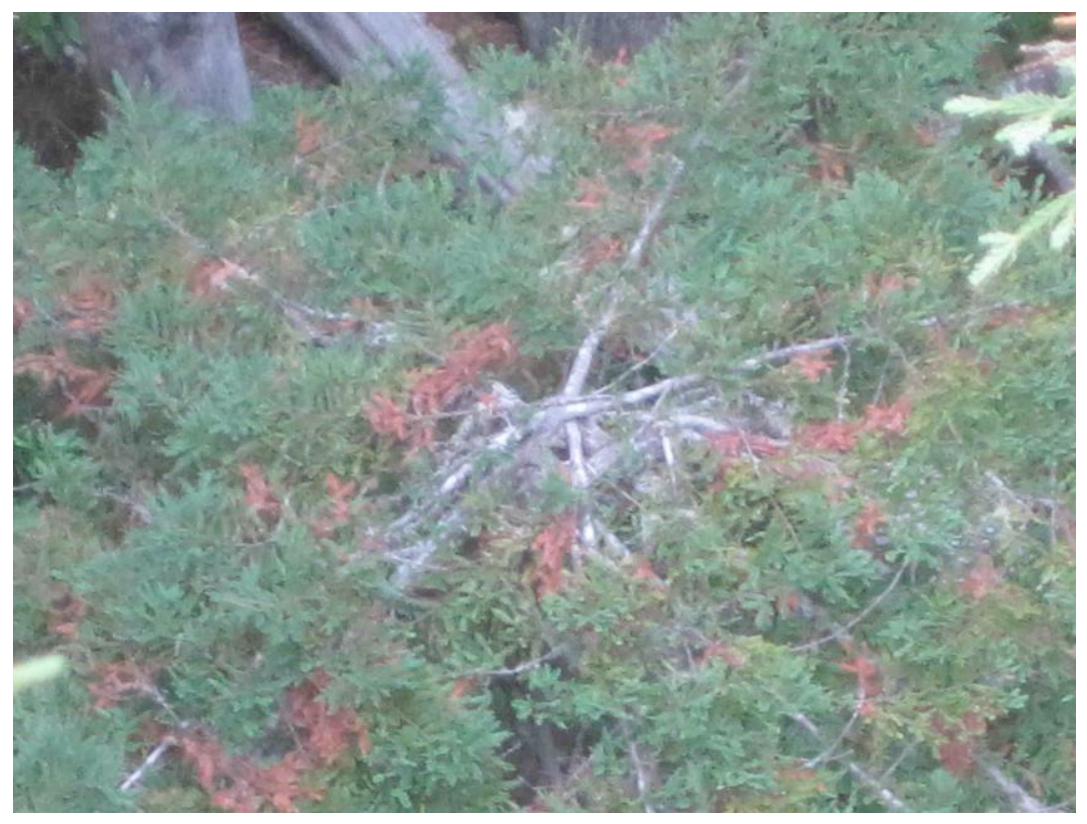

Figure 29. Aerial view of tree $\mathrm{F}$ in Umbrella Grove within transitional stratum. Branches hang down, creating the shape of an umbrella. Photograph was taken from the top of Louie in the RG plot.
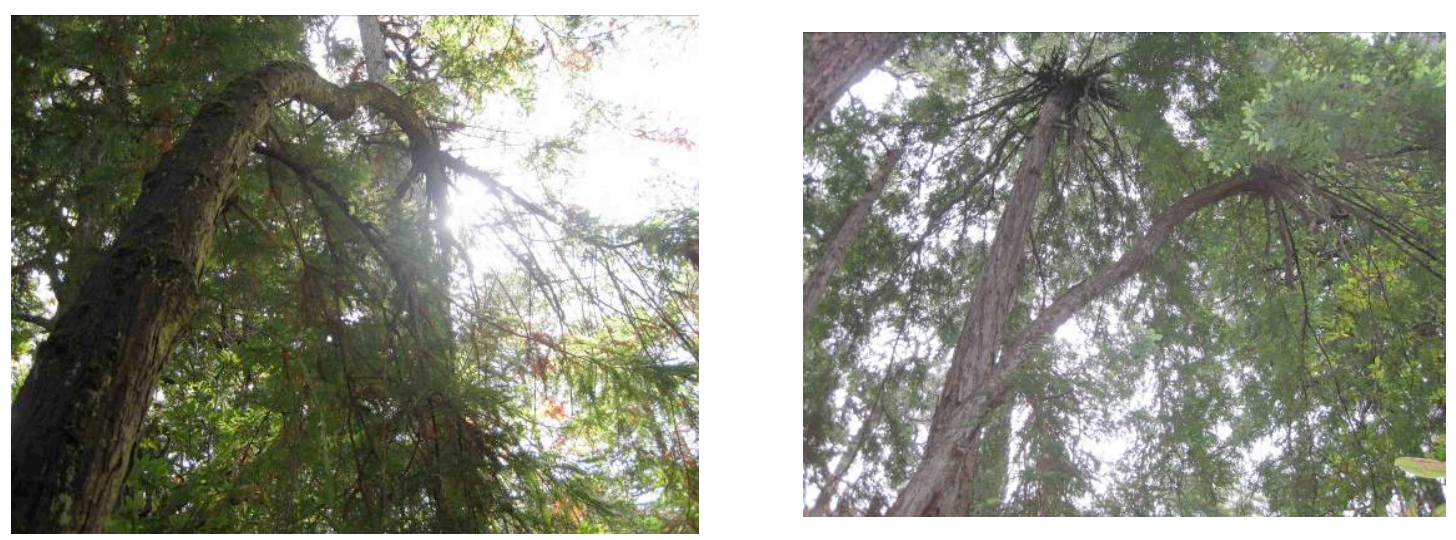

Figure 30. Trees $\mathrm{E}$ and $\mathrm{F}$ in Umbrella Grove within transitional stratum. The canopy of tree $\mathrm{E}$ drooping down (left image). The canopies of trees $\mathrm{E}$ and $\mathrm{F}$ (right image). 
Table 27

Umbrella Grove stems structural characteristics in the transitional stratum

\begin{tabular}{|c|c|c|c|}
\hline Tree & $\mathrm{DBH}(\mathrm{m})$ & $\begin{array}{c}\text { Total } \\
\text { Epiphytes } \\
\end{array}$ & Species \\
\hline A & 1.05 & 14 & Posc \\
\hline B & 0.54 & 1 & Vaov \\
\hline $\mathrm{C}$ & 0.30 & 0 & \\
\hline D & $0.49 \& 1.02$ & 0 & \\
\hline E & 0.32 & 0 & \\
\hline F & .73 & 0 & \\
\hline G & 12.45 & 0 & \\
\hline $\mathrm{H}$ & 8.13 & 0 & \\
\hline
\end{tabular}

\section{Pygmy redwood stratum.}

Inish Man (IN). This plot was in the pygmy redwood stratum. Extensive fire damage to the main tree resulted in a large fire hollow and a circle of eight clonal stems (also known as a fairy ring). IN's clonal formation resembled that of a circle, around which the former complete trunk used to be. At $1.37 \mathrm{~m}(\mathrm{DBH})$, a significant part of the trunk appeared to have succumbed to decay or fire damage (Figure 31). Its DBH measured $2.3 \mathrm{~m}$. IN's total height was $26.1 \mathrm{~m}$. The number of decaying structures increased with height, making it unsafe for limb walking. The total height was gathered from climbing the neighboring clone. In addition, at $16 \mathrm{~m}$ into the crown, an active beehive was established in a reiteration that measured $30.5 \mathrm{~cm}$. The top of IN was dead. However, it did have two live reiterations at $25 \mathrm{~m}$ originating from where the decay began, and an established Huckleberry shrub. Furthermore, the very top of IN had an 
inactive bird's nest (Figure 32). The trunk appeared to be hollowed, and it had an entrance in the shape of a circle.

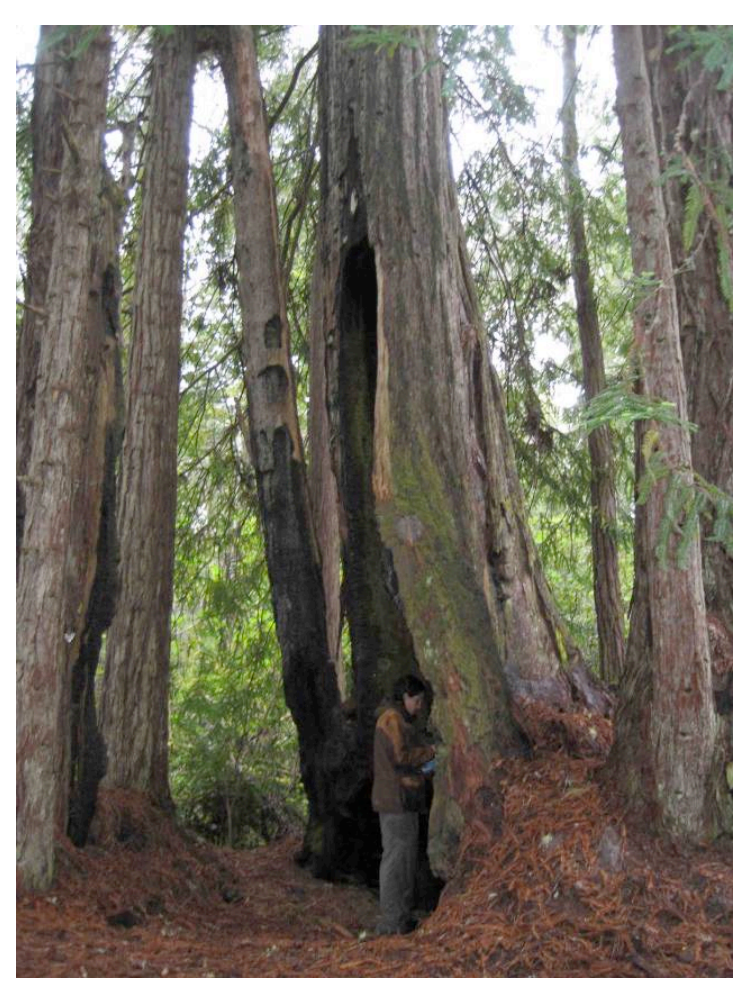

Figure 31. Inish Man fire hollow within pygmy redwood stratum. Internal height was $6.33 \mathrm{~m}$. Researcher height was $1.63 \mathrm{~m}$. 


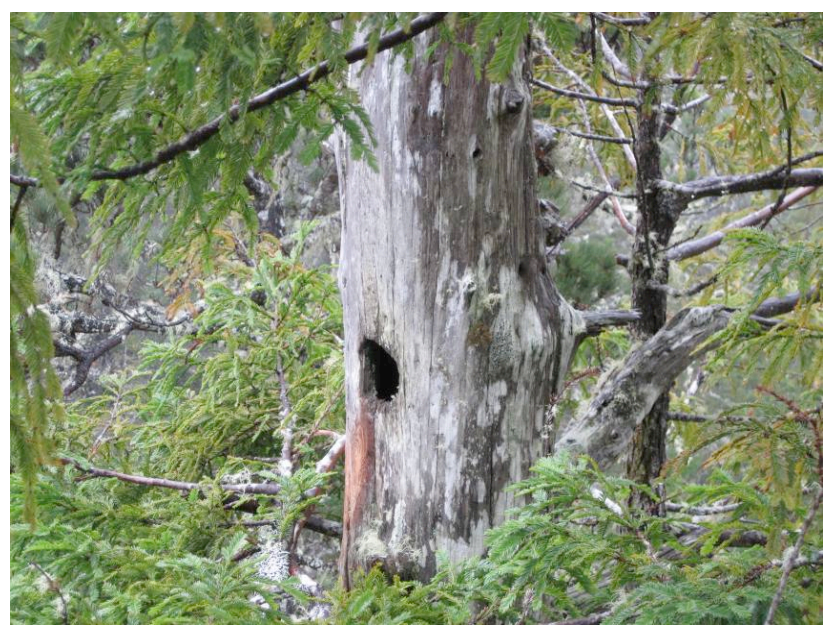

Figure 32. Inish Man's inactive nest.

Picture taken from neighboring clone. Decay started below this point, with two reiterations directly below decay.

IN had a total of 41 structural characteristics, with a basal diameter greater than $15.24 \mathrm{~cm}$ at the trunk (Table 28). These included reiterations, limbs, branches, and trunk, of which the branch was the terminal element or structure. On these structures, a total of 274 epiphytic leather fern and huckleberry were counted and identified in the canopy. A significant number of the epiphytes were established on decaying limbs and crotches (Figure 33). 


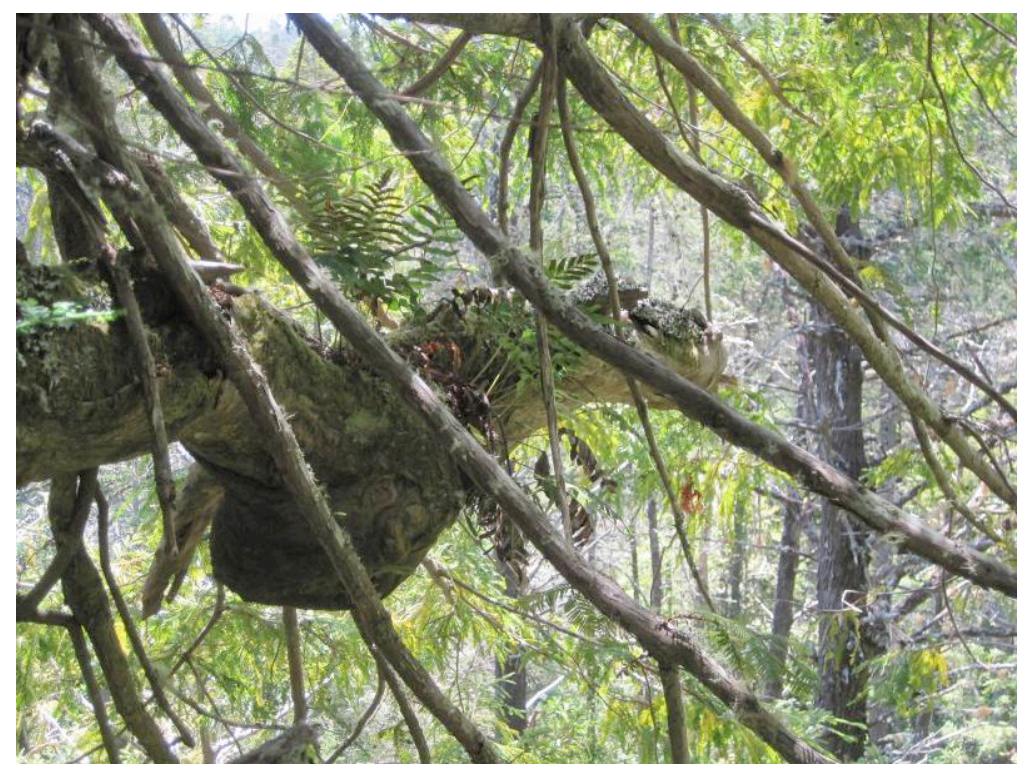

Figure 33. Leather fern (Polypodium scouleri) established on decaying limb in the canopy of Inish Man.

A high frequency of epiphytes were established on decaying wood within the canopy of IN.

Furthermore, IN had a major reiteration with a basal diameter of $66 \mathrm{~cm}, 11.1 \mathrm{~m}$ from the ground with a hierarchical rank of BRLRLRLT (Table 29). It had 223 leather ferns. Huckleberry was not present. The fern mat's surface area measured $98 \mathrm{~cm}^{2}$, and it had a volume of $0.09 \mathrm{~m}^{3}$ arboreal soil. This was the only measureable arboreal soil in the sampled plots within the Russell Unit. Overall, IN had a significant number of unsafe structures, which made characterizations limiting and dangerous. 
Table 28

Inish Man approximate hierarchical ranks in the pygmy redwood stratum

\begin{tabular}{cccc}
\hline Hierarchy rank & $\begin{array}{c}\text { Basal diameter } \\
\text { off trunk }(\mathrm{cm})\end{array}$ & $\begin{array}{c}\text { Total } \\
\text { epiphytes }\end{array}$ & Species \\
\hline BT & 15.24 & 16 & Posc \\
BRLT & 59.06 & 1 & Vaov \\
T & 40.64 & 1 & Vaov \\
BRLT & 57.79 & 1 & Vaov \\
BLT & 25.4 & 10 & Posc \\
BRLT & 31.1 & 13 & Vaov \& Posc \\
T & 66 & 1 & Vaov \\
BT & 15.88 & 2 & Posc \\
LRLT & NM & 1 & Posc \\
RT & $>30.5$ & 2 & Vaov \& Posc \\
BRLT & 20.3 & 3 & Vaov \& Posc \\
BRRLT & 30.5 & 1 & Posc \\
BLT & 30.5 & 0 &
\end{tabular}

Table 29

Inish Man major reiteration

\begin{tabular}{cccc}
\hline $\begin{array}{c}\text { Hierarchy } \\
\text { rank }\end{array}$ & $\begin{array}{c}\text { Basal Diameter } \\
(\mathrm{cm})\end{array}$ & $\begin{array}{c}\text { Total } \\
\text { epiphytes }\end{array}$ & Species \\
\hline RLT & $33 \mathrm{~cm}$ off limb & 42 & Posc \\
BRLRLT & $5.1 \mathrm{~cm}$ off limb & 9 & Posc \\
RLRLRLT & $40.6 \mathrm{~cm}$ & 172 & Posc \\
\hline
\end{tabular}

Note. Complete hierarchical rank was BRLRLRLT. It was $11.1 \mathrm{~m}$ from the base of the tree, and a basal diameter off the main trunk of $66 \mathrm{~cm}$. Epiphytes were established on the limbs. Hierarchy rank RLT had epiphytes between trunk and first reiteration. Rank BRLRLT had small reiteration halting its vertical growth and continue to grow horizontally. RLRLRLT rank is where the leather fern mat was established. The basal diameter of the latter belongs to the last reiteration, since the fern mat expanded to the outside of the structure. 
El Patron (EP). The plot was a single tree in the pygmy redwood stratum. Its total height was $33.46 \mathrm{~m}$, and DBH was $1.42 \mathrm{~m}$. EP had fire marks throughout the trunk up to $9 \mathrm{~m}$. It did not have a fire hollow. It had a dead top, approximately $3 \mathrm{~m}$ from the top down; however, two reiterations originated below where the decay began.

Furthermore, EP had a total of two epiphytes with single pinnae, leather fern (Table 30). However, unlike Inish Man, EP's epiphytes were on a live limb.

Table 30

El Patron hierarchical ranks in the pygmy redwood stratum

\begin{tabular}{ccccc}
\hline $\begin{array}{c}\text { Hierarchy } \\
\text { rank }\end{array}$ & $\begin{array}{c}\text { Height from } \\
\text { ground }(\mathrm{m})\end{array}$ & $\begin{array}{c}\text { Basal } \\
\text { Diameter off } \\
\text { trunk }(\mathrm{cm})\end{array}$ & $\begin{array}{c}\text { Total } \\
\text { epiphytes }\end{array}$ & Species \\
\hline BLT & 9 & 11.18 & 0 & \\
BRLRT & 12.5 & 15.24 & 0 & \\
BT & 14.5 & 16 & 0 & \\
BRLT & 18.5 & 26.67 & 0 & Posc \\
BRLT & 18.5 & 27.94 & 2 & \\
BLRLT & 18.5 & 21.34 & 0 & \\
BRLT & 21 & 19.81 & 0 & \\
BRLT & 21.25 & 13.72 & 0 & \\
BRLT & 22 & 25.4 & 0 & \\
BRLRLT & 23.5 & 25.16 & 0 & \\
BT & 23.25 & 13.46 & 0 & \\
BRLRLT & 23.75 & 12.7 & 0 & \\
BRLT & 24.75 & 15.88 & 0 & \\
BRLT & 27 & 13.21 & 0 & \\
LRT & 28 & 12.45 & 0 & \\
BRRT & 28 & 43.18 & 0 & \\
\hline Note. Epiphytes - Posc: Polypodium scouleri 'Leather Fern’
\end{tabular}


Owl Tree (OT). The plot was a two-stem tree, in the pygmy redwood stratum. It had a total height of $27.43 \mathrm{~m} \pm 5 \mathrm{~m}$ and a DBH of $1.57 \mathrm{~m}$. The clone's DBH was $0.54 \mathrm{~m}$. A large section of the trunk was significantly decayed, making it difficult to access the canopy. A large portion of the trunk had a sponge-like texture near the first reiteration. In addition, OT had a fire hollow that started at the base of the tree and continued throughout the trunk to $12.8 \mathrm{~m}, 2 \mathrm{~m}$ below the first large reiteration. OT's main reiteration (Figure 34) was accessed through the clone. The fire hollow measured a total of $10 \mathrm{~m}^{3}$. It was a nesting site for barn owls from 2008-2010 (Dr. Will Russell, personal communication, January 29, 2011). Accessibility to the top of the tree was hindered by the instability of the decaying trunk, thus characterization of the tree halted at $18.5 \mathrm{~m}$ (Table 31). 


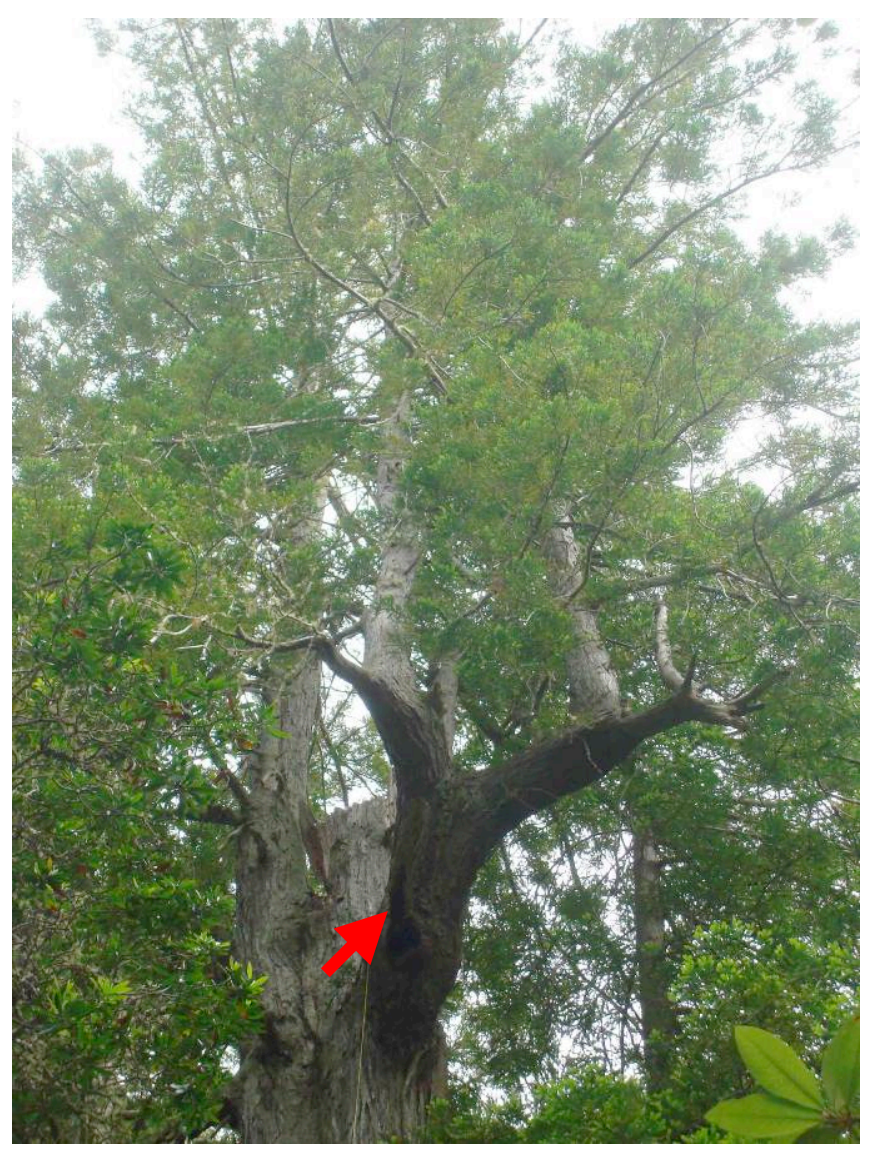

Figure 34. Owl Tree main reiterations.

At the origin of the limb is the opening of the fire hollow (arrow). Structure was $14.62 \mathrm{~m}$ from the ground. Epiphytes established on the base of the limb, below opening of fire hollow. Clone used to access hierarchy rank is on the right. 
Table 31

Owl Tree approximate hierarchical ranks in the pygmy redwood stratum

\begin{tabular}{cccc}
\hline $\begin{array}{c}\text { Hierarchical } \\
\text { rank }\end{array}$ & $\begin{array}{c}\text { Basal } \\
\text { Diameter off } \\
\text { trunk }(\mathrm{cm})\end{array}$ & $\begin{array}{c}\text { Total } \\
\text { epiphytes }\end{array}$ & Species \\
\hline $\begin{array}{c}\text { BRLRRLT } \\
\text { BT }\end{array}$ & 78.11 & 0 & \\
RRT & 12.7 & 2 & Posc \\
RT & 60.96 & 0 & \\
LT & 25.4 & 0 & \\
\hline
\end{tabular}

Note. Epiphytes - Posc: Polypodium scouleri 'Leather Fern'

Unable to characterize to the top of tree due to safety precautions.

Athena (AT). This plot consisted of a tree with two clones originating at the same basal point. It was at the edge of the pygmy redwoods. The largest clone had a total height of $35.1 \mathrm{~m}$ and a DBH of $1.59 \mathrm{~m}$. A fire hollow measured $0.31 \mathrm{~m}^{3}$, with an internal height of $2.73 \mathrm{~m}$. Epiphytes were not observed. However, AT had 11 reiterations (Table 32). At $12.9 \mathrm{~m}$, two large reiterations developed, A and B. The top of reiteration B broke off at $21 \mathrm{~m}$ and developed branching similar to Tree A in the UG plot (Figure 35). The branching at the point of breakage was less than $12.7 \mathrm{~cm}$ in basal diameter. The cluster of branching has resulted in a high collection of needles that receive afternoon sun exposure. The total height for reiteration B was $23 \mathrm{~m}$. Reiteration A continued its vertical growth (Figure 36), exhibiting pronounced apical dominance. The basal diameter for all branches off the main trunk was $<12.7 \mathrm{~cm}$. Also, the main trunk became increasingly thin; at approximately $32 \mathrm{~m}$, the diameter measured close to $12.7 \mathrm{~cm}$. In addition, AT's clone had a total height of $21.7 \mathrm{~m}$, and a DBH of $0.98 \mathrm{~cm}$. Fire marks were observed $3.24 \mathrm{~m}$ up the trunk. Like reiteration B, AT's clone had a broken top. 
Table 32

Athena hierarchical ranks at the edge of the pygmy redwood stratum

\begin{tabular}{ccc}
\hline $\begin{array}{c}\text { Branch } \\
\text { Hierarchy }\end{array}$ & $\begin{array}{c}\text { Basal Diameter } \\
\text { off trunk }(\mathrm{cm})\end{array}$ & Comment \\
\hline BRLRLT & 20.57 & $\begin{array}{c}\text { Partial dead } \\
\text { reiteration. }\end{array}$ \\
BRLLRRLT & 34.04 & Reiteration C. \\
RT & 88.39 & Reiteration A. \\
RT & 80.01 & Reiteration B. \\
BRT & 18.54 & Off of reiteration B \\
BRRT & 24.89 & Off of reiteration B \\
BRT & 23.62 & Off of reiteration B \\
\hline
\end{tabular}

Note. No epiphytes were established within the canopy.
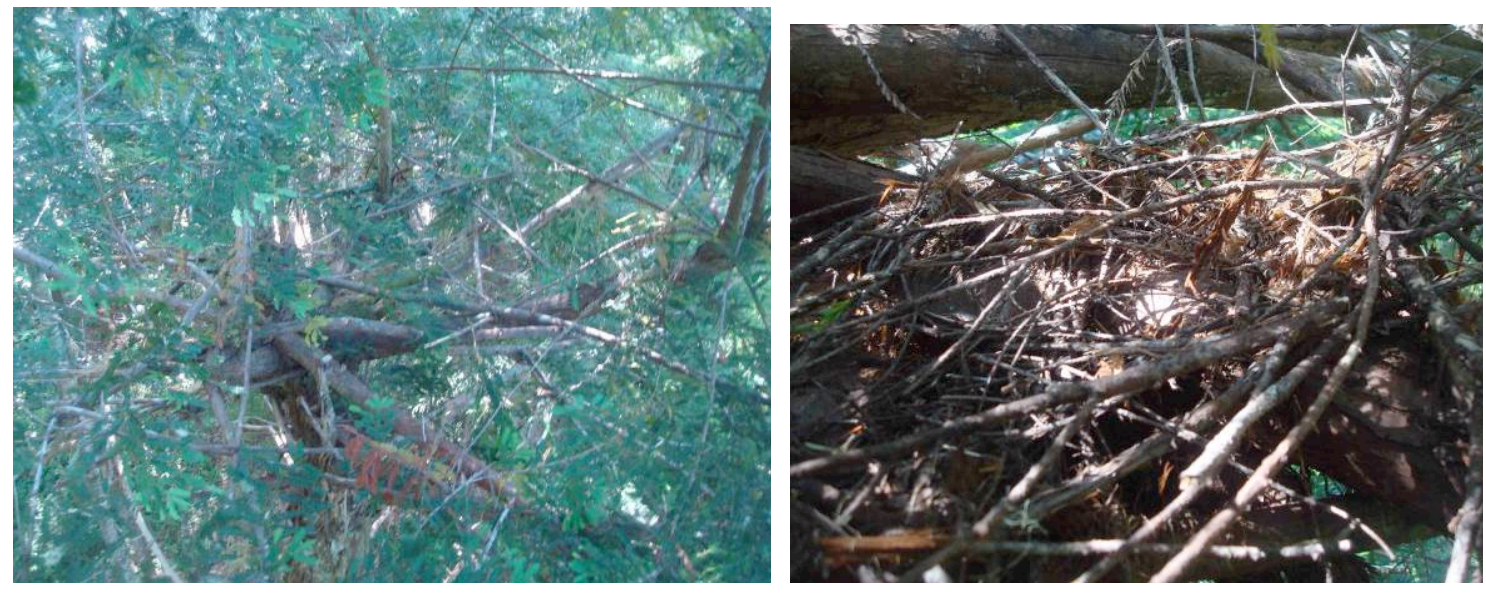

Figure 35. Athena's top of reiteration B.

Right image is a closer look at the needle collection in the branching, whereas left image is an over view of reiteration $\mathrm{B}$. 


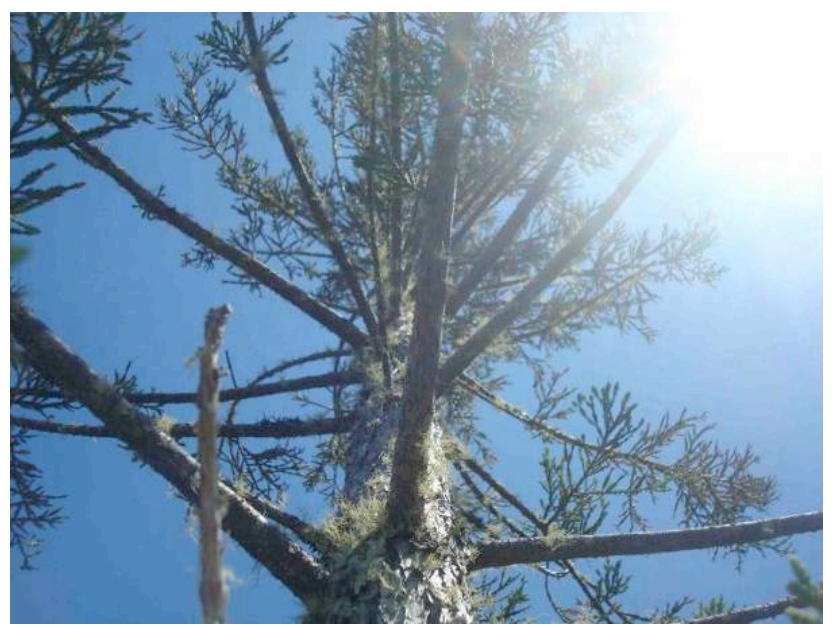

Figure 36. Athena's top of reiteration A.

Approximately $3 \mathrm{~m}$ below the tip of reiteration A. 


\section{DISCUSSION}

This study demonstrated that significant relationships exist between soil properties, structural characteristics, and the growth form of S. sempervirens at the ecotone of a pygmy forest in Mendocino, California. It provided further insight into the complex dynamics of primary forests at the ecotone of a plant community established in edaphic soils. While potassium and water holding capacity significantly influenced total height, DBH was significantly correlated with phosphorous and cation exchange capacity. Also, a significant relationship between number of epiphytic vascular plants and canopy complexity was expected, but the statistical analysis did not detect it.

Interestingly, the number of epiphytic species increased with fire hollow volume. Canopy complexity had a stronger relationship with tree height and size, rather than directly with soil properties. In addition, $\mathrm{pH}$ was expected to have a direct effect on structural growth and canopy complexity. However, that effect was mediated by important soil nutrients, which are in fact influenced by soil $\mathrm{pH}$. They had a more substantial effect on the growth of coast redwood at the ecotone of a pygmy forest than pH by itself.

While soil $\mathrm{pH}$ has been considered a driving factor in the stunted growth of plant species in the pygmy forest, it was not the case for coast redwood at this study site. The lowest $\mathrm{pH}$ levels were measured in the tall pygmy stratum, transitional stratum, and the pygmy redwood stratum. These strata had the highest levels of organic matter. However, in contrast with the results of Yu et al. (1999), who found organic matter to influence plant size and growth, the results from the Russell Unit pygmy forest were not 
correlated with organic matter. Northup et al. (1995) describe plant species growing within the pygmy forest soil formation to have their fine roots growing within the organic humus that collects on the surface because it shelters them from edaphic conditions and it is higher in nutrients. During soil sample collection in the Russell Unit pygmy forest, high densities of fibrous roots were observed within the organic layer. The ericaceous plants within the said strata included glossy leaf manzanita (Arctostaphylos nummularia), huckleberry (Vaccinium ovatum), pacific rhododendron (Rhododendron macrophyllum), and salal (Gaultheria shallon), which are plants considered to have high levels of polyphenol compounds in their foliage once abscised (Northup et al., 1998; Yu et al., 1999). This polyphenol is the most extractable when the plant is in acidic soils (Yu et al., 1999).

Polyphenols, also known as tannins, give an advantage to plants in edaphic soil conditions because they modify the nutrient cycling, thus ameliorating soil toxicity (Northup et al., 1998; Yu et al., 1999). It is argued that an increase in acidic soils results in the plants' increase of polyphenol production, since those same plants will reduce polyphenol production in fertile soils (Yu et al., 1999). Northup et al. (1998) speculate that surplus energy production during photosynthesis is routed to polyphenol production rather than growth. Although, organic matter can also affect $\mathrm{pH}$ levels, neither of these two variables were a driving factor in structural characteristics. However, they should not be disregarded since they are an important factor in the biochemical processes occurring in the soils. Shigo (1998) states that ideal nutrient availability and $\mathrm{pH}$ levels do not exist, since they vary throughout plant communities. 
Maximum tree height was significantly correlated to water-holding capacity and potassium. Water saturation affects the levels of CEC; thus, when water-holding capacity is at an ideal level, the $\mathrm{CEC}$ will be higher since soil nutrients are not being leached away. However, when water-holding capacity is low, $\mathrm{K}$ exchangeability will increase, and $\mathrm{K}$ will not fixate to particles. Also, high organic matter can influence the amount of CEC in the soil. The transitional and redwood pygmy stratum had the greatest DBH and height with a relatively high percentage of organic matter, but low water-holding capacity measurements. In plots in the extreme pygmy stratum with organic matter percent within the acceptable range provided by Brady (1990), water-holding capacity was similar to plots with the tallest trees. This indicates a greater amount of nutrients leaching in the extreme pygmy stratum and short pygmy stratum, and less K fixation in the transitional stratum and pygmy redwood stratum.

Also, a contributing factor to the confinement of absorbing roots to the organic layer may be the result of the limited space they have, due to the clay hardpan, which also contributes to plant dwarfism in the pygmy forest. As mentioned in the literature, the clay in pygmy forest soils retains water molecules more than in other soil types, which might be a factor in the water-holding capacity levels at the Russell Unit pygmy forest. During soil collection, the overall soil texture was classified as sandy loam (for the scope of the study, the iron stained hardpan, B horizon, was not analyzed). In such sandy soils, significantly higher Potassium leaching is observed. Potassium is an essential nutrient in plant and root growth, and aids the plant during environmental stresses (Gliessman, 2007; 
SICCFA, 1980). Although the correlation between the cation exchange capacity and potassium was weak, they both influenced the height of the trees.

Maximum DBH was not correlated with potassium or water-holding capacity. DBH was, however, significantly correlated with cation exchange capacity and phosphorous. Like potassium, phosphorous availability and $\mathrm{CEC}$ are dependent on $\mathrm{pH}$ levels and they are soil properties that significantly drive plant growth and production (Brady, 1990). CEC determines available nutrients to the soil, and when the amount of hydrogen ions is high, it displaces the important nutrients, thus limiting the availability of nutrients to the plants. In low $\mathrm{pH}$ levels, $\mathrm{P}$ becomes insoluble, thus hindering plant growth. In crop production, $\mathrm{P}$ is added in locations where root growth is limited (SICCFA, 1980). Availability of $\mathrm{P}$ is at its maximum in soils with a $\mathrm{pH}$ between 6.5 and 7.0, with most of the available form of P located in the organic humus (Brady, 1990; SICCFA, 1980). The highest $\mathrm{pH}$ measured was in the pygmy redwood stratum (5.0), and lowest in the tall pygmy stratum (3.7). In addition, all plots had very low levels of $\mathrm{P}$ ppm, including the pygmy stratum. The extreme pygmy stratum had smaller trunks at their DBH, but the difference in P throughout the stratum was not significant. Therefore, within the Russell Unit pygmy forest/ecotone, P and CEC availability were significantly limited by $\mathrm{pH}$, thus hindering plant growth.

Nutrient leaching also causes low levels of cation exchange capacity. A typical soil profile in the pygmy forests consists of a sandy layer above a clay hardpan; this was reflected in the cation exchange capacity levels of the soil samples. CEC throughout the strata was within the soil order of sand and clay (Brady, 1990). The percent cation 
saturation showed a significantly high percentage of hydrogen saturation within cation exchange capacity, where the important soil nutrients saturation $(\mathrm{K}, \mathrm{Mg}, \mathrm{Ca}, \mathrm{Na}$ ) was low for all the strata. Hydrogen ions are adsorbed by the soil at a greater rate than other nutrients, probably a consequence of the nutrient leaching. In general, clay and sandy soils have the lowest levels of cation exchange capacity.

The number of stems per plot decreased as maximum tree height increased. The natural forest processes of competition, reproduction, and disturbances predict this correlation. Douhovnikoff et al. (2004) speculate that soils supporting vegetation provide a limited amount of resources to a restricted number of plants. Light availability also influences stand density. It is probable that plots with tight stand density likely have limited nutrients availability, resulting in nutrient conservation rather than allocating them to growth and production.

Plots in the pygmy redwood and transitional strata were the only plots where fire marks or fire hollows were observed, with the exception of the YG plot, which was between the short and tall pygmy strata. Six out of the eight trees within the Umbrella Grove had fire marks, and one had a fire hollow. Brown and Baxter (2003) reconstructed fire history by using fire scars on tree rings in old-growth Sequoia sempervirens on the Jackson Demonstration State Forest in the coastal area of Mendocino County. They were able to date fire scars back to the early 1700 s, and determine that fire frequency was high and uniform in the different plant communities. The site with the longest intermission was a pygmy forest on the westernmost section of the entire study site. Brown and Baxter (2003) research observed a halt in fire frequency after 1930. Although the 
research was carried out approximately $10 \mathrm{~km}$ north of the Russell Unit, the recorded history of fire frequency might be applicable to the rest of the surrounding forests since natural disturbances are stochastic events that have no boundaries.

Redwood forests experienced fire disturbances well before human activity (Brown \& Baxter, 2003; Johnston, 1994). Douglas and Bendure (2012) found that within S. sempervirens forests, DBH, cambium kill, and percent canopy loss were good predictors of mortality rates due to fire; though the above-ground plant was killed, the roots resprout the following year. The trees between the extreme and tall pygmy strata are at a disadvantage since it is possible their energy goes to conserving nutrients rather than using them to put out more growth. Nutrient deficiency may prevent them from developing the thick, fire-resistant bark observed in giant stands in redwood forests, making them more susceptible to fires. The FG plot was the only plot within the extreme pygmy stratum that had trees with mature bark. Douglas and Bendure (2012), however, showed that redwoods with a DBH of less than $20 \mathrm{~cm}$ had a significantly higher mortality rate during a fire. The average $\mathrm{DBH}$ in the extreme pygmy strata was less than $20 \mathrm{~cm}$.

From the fire hollows to the fire marks, it is evident the pygmy forest/ecotone in the Russell Unit has experienced fire. Therefore, it is probable that during the last fire, above-ground vegetation was killed, and what was characterized in the extreme pygmy and short pygmy stratum was the sprouting from the old rootstock. The last fire in the area may be equivalent to the age of the coast redwoods in the extreme pygmy and short pygmy stratum. The pygmy/ecotone forest in the Russell Unit has not experienced 
anthropomorphic activities, such as logging or development. This supports the theory of past natural fire frequencies in the area.

It was interesting to observe a strong and significant correlation between fire hollows and epiphytes. In addition, except for the Hogs Grove plot, most of the epiphytes recorded were established on limbs that had fire scars, were in decay, and/or were dead. This decomposing wood is likely to provide high nutrient-rich humus for the established vascular plants. Nevertheless, the only fern mat recorded in the entire study site was on a live limb that had actual arboreal soil development. This finding was consistent with those of other redwood canopy studies. Other studies have found a strong positive correlation between canopy structures and epiphytes. The physiognomy within each stratum of the pygmy forest to the ecotone, including, size, DBH, and canopy complexity changed drastically throughout the strata due to soil characteristics. Finally, the study site boundary was at the edge of the pygmy redwoods, before the extreme redwood stratum, and it is possible that more data is required, since the Pearson's correlation was strong and significant for maximum height, maximum DBH, and canopy complexity. 


\section{CONCLUSION}

An old-growth forest, as originally defined, is one that has developed naturally over time without significant human impact (i.e., never been logged). Old-growth coast redwood that exists on productive sites is known for characteristics such as very large trees, complex canopy structures, and the near complete dominance of Sequoia sempervirens. However common these characteristics may be, they do not define old growth. On the contrary, on the edge of its ecological tolerance, redwood grows in scattered clusters of bonsai-like trees in a sea of pygmy endemics. These usual growth forms and patterns, found in pygmy forests, expand the notion of old-growth redwoods to include some of the smallest, as well as the tallest, trees in the world.

The complexities of the edaphic conditions of pygmy forests are such that each nutrient deficiency affects the coast redwood differently. Phosphorous influences growth, maturity, and reproduction, whereas potassium is responsible for strong trunks. Cation exchange capacity determines the ions available to the plant root and is significantly influenced by hydrogen ions and organic matter. Whereas water-holding capacity in soils can leach out nutrients before the plant absorbs them. Further studies on soil analysis could include soil nitrogen levels, and a comprehensive depth to hardpan analysis. In addition, due to the high production of polyphenols in ericaceous plants, a foliar study of polyphenols throughout the strata is recommended due to the high frequency of these plant species. The latter is recommended because the organic layer within the strata was rated relatively high and is a contributing factor in plant fitness and polyphenols within pygmy forests. 
Natural process and disturbances, such as fires, are important in all natural plant communities. The relationship between epiphytic density in the canopy and fire hollow volumes is an example of such disturbances, even in an ecosystem with edaphic soil conditions. Plant communities are driven by a vast array of biotic and abiotic factors, some of which are edaphic conditions that influence their physiognomy and adaptation. Coast redwoods are capable of adapting to edaphic soil conditions, and their growth, like the rest of the pygmy plant species, is stunted and different than that of coast redwoods growing in productive soils. Although, soil conditions are not ideal, they continue to grow, and develop unique growth structures, even within extreme pygmy conditions.

This study demonstrated that coast redwoods, within the pygmy forest and at the ecotone of extreme redwoods, are capable of developing complex structural characteristics. Such characteristics can support epiphytic plants, and associated vertebrates, invertebrates, and lichen. A continuous study of these relationships would further expand the literature on canopy ecology in the pygmy forest. Processes that are unassuming in productive coast redwood stands, are imperative to coast redwoods in the pygmy forest. Determining the importance of these processes in edaphic conditions can further protect these species and all habitats they create.

Management schemes such as thinning to promote old-growth characteristics, and as a fire surrogate, are not supported by this study. Such methods include harvesting trees with a small DBH to encourage wood production and reduce the likelihood of a high-intensity fire. Old-growth redwoods on the edge of their ecological tolerance, as demonstrated by this study, can include very small trees. In addition, the importance of 
fire in the creation of fire hollows is far more critical to canopy ecology, than previously thought. As described by Spies (2009), old growth forests are a result of stochastic events that do no follow a uniform pattern. Also, coast redwoods within high-density plots, although short and small, were still able to adapt, compete, and continue to live. Even within extreme pygmy vegetation, this study showed the coast redwood developing thick mature bark on stems that would be considered insignificant in a thinning operation. And although it is unknown when was the last fire that went through the Russell Unit, coast redwoods survived and continued to provide support to epiphytes and wildlife.

Although Sequoia sempervirens from the extreme pygmy forest to the ecotone did not reach the towering heights of its counterpart in productive old-growth forests, it did exhibit old-growth characteristics, some of which had never been documented before. If the characterization of old-growth remains linked to height and wood volume, Sequoia sempervirens growing in pygmy forest types will be repeatedly overlooked, when in fact they are part of a new definition of old-growth redwood. 


\section{REFERENCES}

A \& L Plains Labs, Inc. (n.d.). Soil analysis, sample report with reference guide explanations. Retrieved from http://www.al-labs-plains.com/soil.html

Aitken, S. N., \& Libby, W. J. (1994). Evolution of the pygmy-forest edaphic subspecies of Pinus contorta across an ecological staircase. Evolution, 48, 1009-1019.

Baker, L. M., Peery, Z. M., Burkett E. E., Singer, S. W., Suddjian, D. L., \& Beissinger, S. R. (2006). Nesting habitat characteristics of the Marbled Murrelet in central California redwood forests. Journal of Wildlife Management, 70, 939-946.

Borchert, M., Segotta, D., \& Purser, M. D. (1988). Coast redwood ecological types of southern Monterey County, California. Technical Report, September. Washington, DC: U.S. Department of Agriculture Forest Service.

Brady, N. C. (1990). The nature and the properties of soils $\left(10^{\text {th }}\right.$ ed.). New York: Macmillan Publishing Company.

Brown, P. M., \& Baxter, W. T. (2003). Fire history in the coast redwood forests in the Mendocino coast, California. Northwest Science, 77(2), 147-158.

Clark, K. L., Nadkarni, N. M., \& Gholz, H. L. (1998). Growth, net production, litter decomposition, and net Nitrogen accumulation by epiphytic bryophytes in a tropical montane forest. Biotropica, 30(1), 12-23.

Cooperrider, A., Noss, R. F., Welsh, H. H., Jr., Carroll, C., Zielinski, W., Olson, D, Nelson, S. K., \& Marcot, B. G. (2000). Chapter 5: Terrestrial fauna of the redwood forests. In R. F. Noss (Ed.), The redwood forest: History, Ecology, and conservation of the coast redwood (pp. 119-163). Washington, DC: Island Press.

Dawson, T. E. (1998). Fog in the California redwood forests: Ecosystem inputs and use by plants. Oecologia 117, 476-485.

Douglas, R. B., \& Bendure, T. (2012). Post-fire response of coast redwood one year after the Mendocino lightning complex fires. In R. B. Standiford, R. B. Weller, D. D. Piirto, \& J. D. Stuart (Eds.), Proceedings of the coast redwood forests in a changing California: A symposium for scientist and managers (pp. 363-371). Gen. Tech. Rep. PSW-GTR-238. Albany, CA: Pacific Southwest Research Station, Forest Service, U.S. Department of Agriculture.

Douhovnikoff, V., Cheng, A. M., \& Dodd, R. S. (2004). Incidence, size and spatial structure of clones in second-growth stands of coast redwood, Sequoia sempervirens (Cupressaceae). American Journal of Botany, 91, 1140-1146. 
Ellyson, W. J. T., \& Sillett, S. (2003). Epiphyte communities on Sitka spruce in an oldgrowth redwood forest. The Bryologist, 106(2), 197-201.

Enloe, H. A., Graham, R. C., \& Sillett, S. C. (2006). Arboreal histosols in old-growth redwood forest canopies, northern California. Soil Science Society of America Journal, 70, 408-418.

Erwin, L. T. (1982). Tropical forests: Their richness in Coleoptera and other arthropod species. The Coleopterists Society, 36(1), 74-75.

Fox, W. W. (1976). Pygmy forest: An ecological staircase. California Geology, 29(1), 17.

Frelich, L. E., \& Reich, P. B. (2003). Perspectives on development of definitions and values related to old-growth forests. Environmental Reviews, 11, S9-S22.

Giusti, G. A. (2004). Structural characteristics of an old-growth coast redwood stand in Mendocino County, California. Paper presented at the Redwood Science Symposium: What does the Future Hold? Rohnert Park, California. March 15-17.

Gliessman, S. R. (2007). Agroecology: The ecology of sustainable food systems (2 ${ }^{\text {nd }}$ ed.). New York: Taylor \& Francis Group.

Hanson, C. (2010). The myth of "catastrophic" wildfire: A new ecological paradigm of forest health. John Muir Project. Technical Report. Retrieved from http://johnmuirproject.org/

Harris, J. G., \& Harris, M. W. (2001). Plant identification terminology: An illustrated glossary $\left(2^{\text {nd }}\right.$ ed.). Spring Lake, UT: Spring Lake Publishing.

Hayes, J. P., Chan, S. S., Emmingham, W. H., Tappeiner, J. C., Kellogg, L., D., \& Bailey, J. D. (1997). Wildlife response to thinning young forests in the Pacific Northwest. Journal of Forestry, 95(8), 28-33.

Helms, J. A. (2004). Old-growth: What is it? Journal of Forestry, 102(3), 8-12.

Ishii, H., Ford, E. D., \& Dinnie, C. E. (2002). The role of epicormic shoot production in maintaining foliage in old Pseudotsuga menziesii (Douglas-fir) trees II. Basal reiteration from older branch axes. Botany, 80, 916-926.

Jenny, H. (1973). The pygmy forest ecological staircase: A description and interpretation. Berkeley: University of California. 
Johnston, V. R. (1994). California forest and woodlands: A natural history. Berkeley: University of California Press.

Kopittke, P. M., \& Menzies, N. W. (2007). A review of the use of the basic cation saturation ratio and the "ideal" soil. Soil Science Society of America Journal, 71, 259-265.

LaHaye, W. S., \& Gutiérrez, R. J. (1999). Nest sites and nesting habitat of the northern spotted owl in northwestern California. The Condor, 101, 324-330.

Lilly, S. J. (2010). Arborists' certification study guide. Champaign, IL: International Society of Arboriculture.

Little, E. L. (1980). National Audubon Society field guide to North American trees. New York: Alfred A. Knopf.

Lowman, M. D., \& Rinker, H. B. (Eds.). (2004). Forest canopies $\left(2^{\text {nd }}\right.$ ed.). Burlington, MA: Elsevier Academic Press.

Mahony, T. M., \& Stuart, J. D. (2000). Old-growth forest associations in the northern range of the coastal redwood. Madroño, 47(1), 53-60.

Mahony, T. M., \& Stuart, J. D. (2004). Status of vegetation classification in redwood ecosystems. Paper presented at the Redwood Science Symposium: What does the Future Hold? Rohnert Park, California. March 15-17.

Mazurek, M. J., \& Zielinski, W. (2003, April 29). The importance of the individual legacy old-growth tree in the maintenance of biodiversity in commercial redwood forests. Pacific Southwest Research Station. Berkeley, CA. U.S. Department of Agriculture.

Murphy, D. D., \& Noon, B. R. (1992). Integrating scientific methods with habitat conservation planning: Reserve design for northern spotted owls. Ecological Applications, 2(1), 3-17.

Nadkarni, N. M. (1994). Diversity of species and interactions in the upper tree canopy of forest ecosystems. American Zoologist, 34(1), 70-78.

Nadkarni, N. M., Parker, G. G., Rinker, H. B., \& Jarzen, D. M. (2004). The nature of forest canopies. In M. D. Lowman, \& H. B. Rinker (Eds.), Forest canopies $\left(2^{\text {nd }}\right.$ ed., pp. 3-23). Burlington, MA: Elsevier Academic Press. 
Northup, R. R., Dahlgren, R. A., \& McColl, J. G. (1998). Polyphenols as regulators of plant-litter-soil interactions in northern California's pygmy forest: A positive feedback? Biogeochemistry, 42(1/2), 189-220.

Northup, R. R., Dahlgren, R. A., \& Yu, Z. (1995). Intraspecific variation of conifer phenolic concentration on a marine terrace soil acidity gradient; a new interpretation. Plant and Soil, 171, 255-262

Russell, W., \& Hageseth Michels, K. (2010). Stand development on a 127-yr chronosequence of naturally regenerating Sequoia sempervirens (Taxodiaceae) forests. Madroño, 57, 229-241.

Russell, W., \& Woolhouse, S. (2012). 'Pygmy' old-growth redwood characteristics on an edaphic ecotone in Mendocino County, California. In R. B. Standiford, R. B. Weller, D. D. Piirto, \& J. D. Stuart (Eds.), Proceedings of coast redwood forests in a changing California: A symposium for scientists and managers (pp. 304311). Gen. Tech. Rep. PSW-GTR-238. Albany, CA: Pacific Southwest Research Station, Forest Service, U.S. Department of Agriculture.

Sawyer, J. O., Gray, J., West, G. J., Thornburgh, D. A., Noss, R. F., Engbeck, J. H., Jr., Marcot, B. G., \& Raymond, R. (2000a). Chapter 2: History of redwood and redwood forests. In R. F. Noss (Ed.), The redwood forest: History, ecology, and conservation of the coast redwood (pp. 7-38). Washington, DC: Island Press.

Sawyer, J. O., Sillett, S. C., Libby, W. J., Dawson, T. E., Popenoe, J. H., Largent, D. L., Van Pelt, R., ... Del Tredici, P. (2000c). Chapter 4: Redwood trees, communities, and ecosystems: A closer look. In R. F. Noss (Ed.), The redwood forest: History, ecology, and conservation of the coast redwood (pp. 81-118). Washington, DC: Island Press.

Sawyer, J. O., Sillett, S. C., Popenoe, J. H., LaBanca, A., Sholars, T., Largent, D. L., Euphrat, F.,... Van Pelt, R. (2000b). Chapter 3: Characteristics of redwood forests. In R. F. Noss (Ed.), The redwood forest: History, ecology, and conservation of the coast redwood (pp. 39-79). Washington, DC: Island Press.

Shigo, A. (1998). Modern arboriculture: A system approach to the care of trees and their associates. Snohomish, WA: Shigo and Trees, Associates. (Orig. pub. 1991.)

Shigo, A. (2008). A new tree biology and dictionary: Facts, photos, and philosophies on trees and their problems and proper care. Snohomish, WA: Shigo and Trees, Associates. (Orig. pub. 1986.)

Sillett, S. C. (1999). Tree crown structure and vascular epiphyte distribution in Sequoia sempervirens rain forest canopies. Selbyana, 20(1), 76-97. 
Sillett, S. C., \& McCune, B. (1998). Survival and growth of Cyanolichen transplants in Douglas-fir forest canopies. The Bryologist, 101(1), 20-31.

Sillett, S. C., \& Van Pelt, R. (2000a). A redwood tree whose crown is a forest canopy. Northwest Science, 74(1), 34-43.

Sillett, S. C., \& Van Pelt, R. (2000b). A redwood tree whose crown may be the most complex on earth. L'Abre, 11-18.

Sillett, S. C., \& Van Pelt, R. (2007). Trunk reiteration promotes epiphytes and water storage in an old-growth redwood forest canopy. Ecological Monographs, 77, 335-359.

Sillett, S. C., Van Pelt, R., Koch, G. W., Ambrose, A. R., Carroll, A. L., Antoine, M. E., \& Mifsud, B. M. (2010). Increasing wood production though old age in tall trees. Forest Ecology and Management, 259, 976-994.

Soil Improvement Committee, California Fertilizer Association (SICCFA). (1980). Western fertilizer handbook ( ${ }^{\text {th }}$ ed.). Danville, IL: The Interstate Printers \& Publishers, Inc.

Spickler, J. C., Sillett, S., Marks, S. B., Welsh, H. H., Jr. (2006). Evidence of a new niche for a North American salamander: Aneides vagrans residing in the canopy of oldgrowth redwood forest. Herpetological Conservation and Biology, (1), 16-26.

Spies, T. (2009). Chapter 3: Science of old growth, or a journey into wonderland. In T. A. Spies \& S. L. Duncan (Eds.), Old growth in a new world: A Pacific Northwest reexamination (pp. 31-43). Washington, DC: Island Press.

Spies, T. A., \& Duncan, S. L. (2009). Chapter 1: Searching for old growth. In T. A. Spies \& S. L. Duncan (Eds.), Old growth in a new world: A Pacific Northwest reexamination (pp. 3-11). Washington, DC: Island Press.

Stokes, B. J., Ashmore, C., Rawlings, C., \& Sirois, D. L. (1989). Glossary of terms in timber harvesting and forest engineering. General Technical Report SO-73. New Orleans, LA: U.S. Department of Agriculture Forest Service.

Stone, E. C., \& Vasey, R. B. (1968). Preservation of coast redwood on alluvial flats. Science, 159(3811), 157-161.

Stuart, J. D., \& Sawyer, J. (2001). Trees and shrubs of California. Los Angeles: University of California Press. 
Tucker, R. M. (1999). Essential plant nutrients: Their presence in the North Carolina soils and role in plant nutrition. North Carolina Department of Agriculture and Consumer Services (October). Retrieved from www.ncagr.gov/agronomi/pdffiles/essnutr.pdf

Van Pelt, R., \& Nadkarni, N. M. (2004). Development of canopy structure in Pseudotsuga menziesii forests in the Southern Washington Cascades. Forest Science, 50, 326-341.

Van Pelt, R., \& North, M. P. (1996). Analyzing canopy structure in Pacific Northwest old-growth forests with a stand-scale crown model. Northwest Science, 70, 15-30.

Van Pelt, R., \& Sillett, S. (2008). Crown development of coastal Pseudotsuga menziesii including a conceptual model for tall conifers. Ecological Monographs, 78, 283311.

Waring, R. H., \& Major, J. (1964). Some vegetation of the California coastal redwood region in relation to gradients of moisture, nutrients, light, and temperature. Ecological Monographs, 34, 167-215.

Westman, W. E. (1975). Edaphic climax pattern of the pygmy forest region of California. Ecological Monograph, 45, 109-135.

Westman, W. E., \& Whittaker, R. H. (1975). The pygmy forest region of northern California: Studies on biomass and primary productivity. Journal of Ecology, 63, 493-520.

Yu, Z., Dahlgren, R. A., \& Northup, R. R. (1999). Evolution of soil properties and plant communities along an extreme edaphic gradient. European Journal of Soil Biology, 35(1), 31-38.

Zielinski, W. J., \& Gellman, S. T. (1999). Bat use of remnant old-growth redwood stands. Conservation Biology, 13(1), 160-167.

Zinke, P. J. (1988). The redwood forest and associated north coast forests. In M. G. Barbour \& J. Major (Eds.), Terrestrial vegetation of California (pp. 679-698). Davis, CA: California Native Plant Society. 


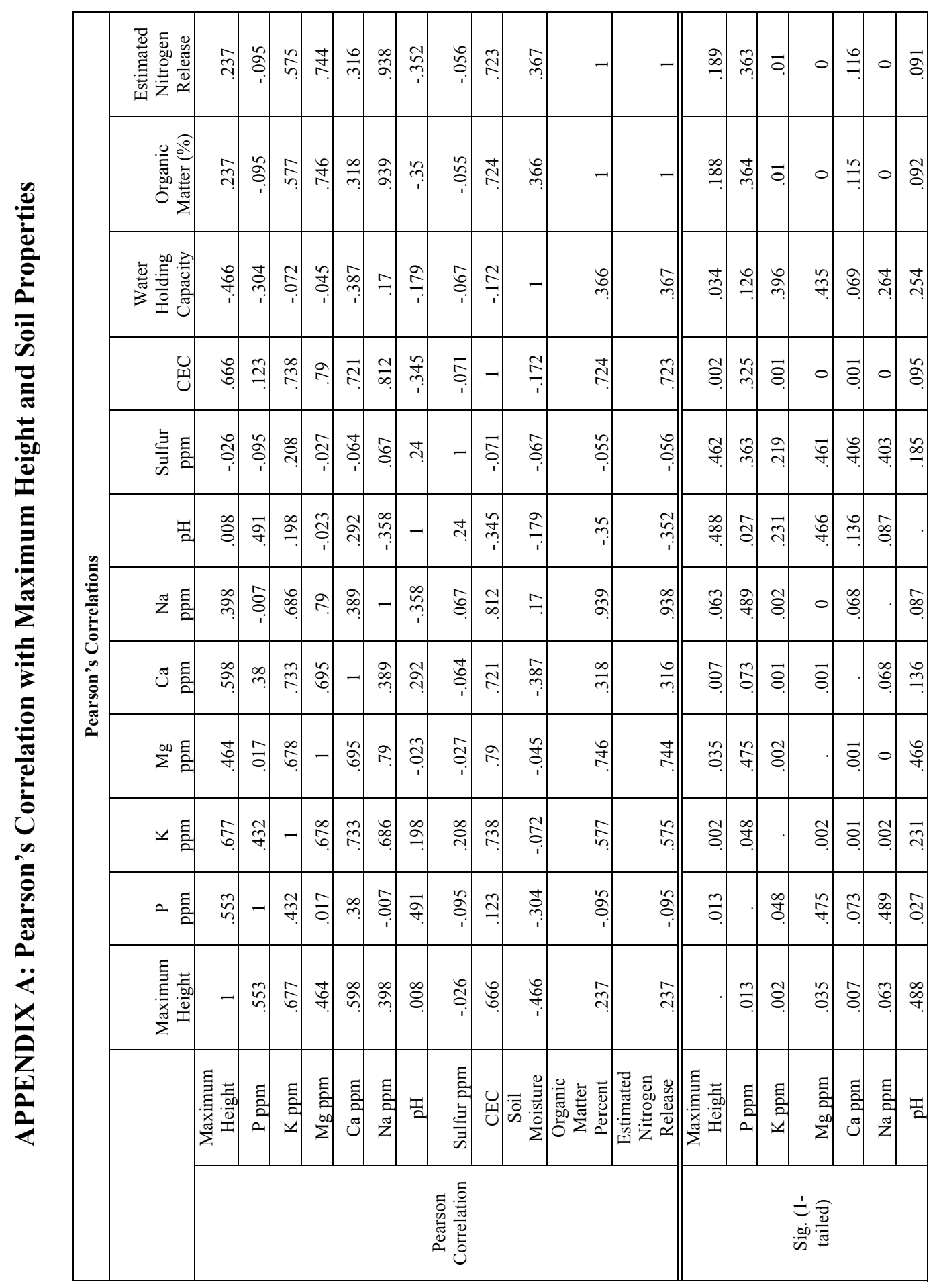




\begin{tabular}{|c|c|c|c|c|c|c|c|c|c|c|c|c|c|c|c|c|c|}
\hline & 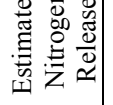 & $\begin{array}{l}\infty \\
\vec{f} .\end{array}$ & $\overrightarrow{\mathrm{a}}$ & $\stackrel{\infty}{\square}$. & 0 & & -6 & - & 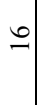 & 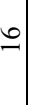 & - & $\because 0$ & $0 \quad-$ & $=$ & 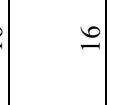 & 의 & $\underline{0}$ \\
\hline & 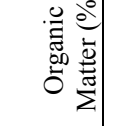 & ร. & $\overline{\mathrm{a}}$ & o. & & 0 & 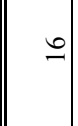 & $=$ & 0 & -2 & -2 & $=0$ & 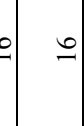 & -2 & $\stackrel{6}{-1}$ & 의 & $\stackrel{0}{0}$ \\
\hline & 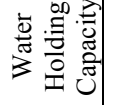 & $\stackrel{q}{q}$ & 유ํ & & 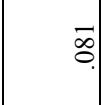 & , & -6 & $=$ & $=$ & 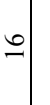 & -2 & 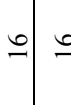 & 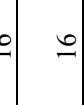 & 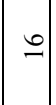 & $\stackrel{6}{-1}$ & $=$ & ? \\
\hline & $\begin{array}{l}0 \\
\text { I⿱⿴囗十丌 }\end{array}$ & ભે & & స్తి & $\bar{\Xi}$ & పे. & $\stackrel{0}{-1}$ & 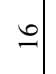 & 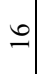 & - & 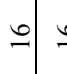 & $\div$ & - & - & 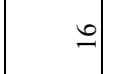 & 의 & $\stackrel{0}{0}$ \\
\hline & 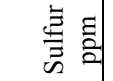 & & ఏ్ & $\tilde{q}$. & ร. & $\stackrel{\infty}{\neq}$ & $\div$ & 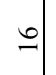 & 6 & 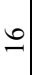 & $=1$ & $=0$ & 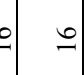 & 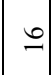 & 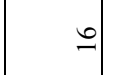 & - & $\stackrel{0}{\circ}$ \\
\hline & $\frac{\pi}{2}$ & $\stackrel{\infty}{\infty}$ & $\because$ & 苂 & ธุ. & จे़ी & $\div$ & 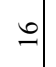 & - & 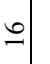 & $=$ & 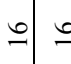 & $\div$ & $\div$ & - & 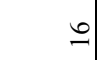 & $\stackrel{6}{\circ}$ \\
\hline 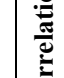 & $\widetilde{z}$ 站 & ợ. & 0 & 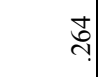 & 0 & 0 & 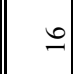 & 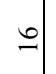 & 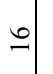 & 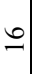 & $0=$ & $\div 0$ & 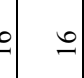 & $?$ & 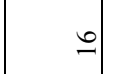 & 의 & $\stackrel{\circ}{-}$ \\
\hline 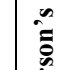 & లే & ๖े. & $\overline{\mathrm{s}}$ & हे & $\stackrel{n}{?}$ & $\stackrel{?=}{=}$ & 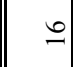 & $\stackrel{-}{-1}$ & 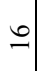 & 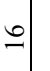 & 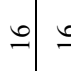 & $\because 0$ & ㄴ. & 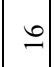 & 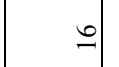 & $\stackrel{-}{-1}$ & $\stackrel{0}{-}$ \\
\hline & $\sum^{\infty}$ & to. & 0 & $\stackrel{\overbrace{}}{f}$ & 0 & 0 & 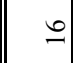 & 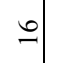 & -9 & $\stackrel{0}{-1}$ & 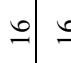 & $\div=$ & $0 \quad 0$ & $\div$ & $\div$ & - & $\stackrel{\circ}{\circ}$ \\
\hline & $\simeq$ & ते & $\overline{\mathrm{a}}$ & ?ి. & a. & a & 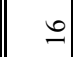 & $=$ & ? & 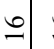 & 0 & $=0$ & $\stackrel{0}{0}$ & 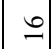 & 6 & 0 & $\underline{0}$ \\
\hline & $\therefore$ a & | & ڤે & $\stackrel{?}{\simeq}$ & 常: & 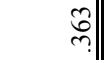 & $\div$ & 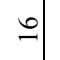 & $\stackrel{?}{-}$ & 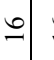 & $=0$ & $\because$ & $0 \quad 0$ & $\div$ & $\stackrel{0}{-}$ & $\stackrel{0}{-}$ & $\stackrel{\circ}{\sim}$ \\
\hline & 言 & . & ธิ & 仓े. & $\begin{array}{c}\infty \\
\stackrel{\infty}{?} \\
?\end{array}$ & $\stackrel{0}{\|}$ & $\stackrel{\bullet}{-}$ & 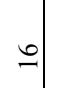 & - & 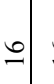 & $=0$ & $=0$ & $0 \quad 0$ & -2 & $\stackrel{0}{-}$ & - & $\stackrel{\bullet}{\simeq}$ \\
\hline & & 害言 & ن) & 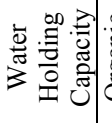 & 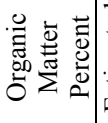 & 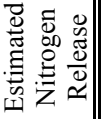 & 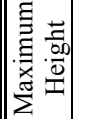 & 辛 & 咅 & 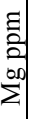 & 路 & 空 & 㝘 & $=0$ & 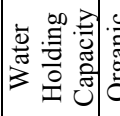 & 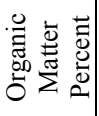 & 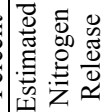 \\
\hline & & 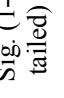 & & & & & & & & & & & z & & & & \\
\hline
\end{tabular}




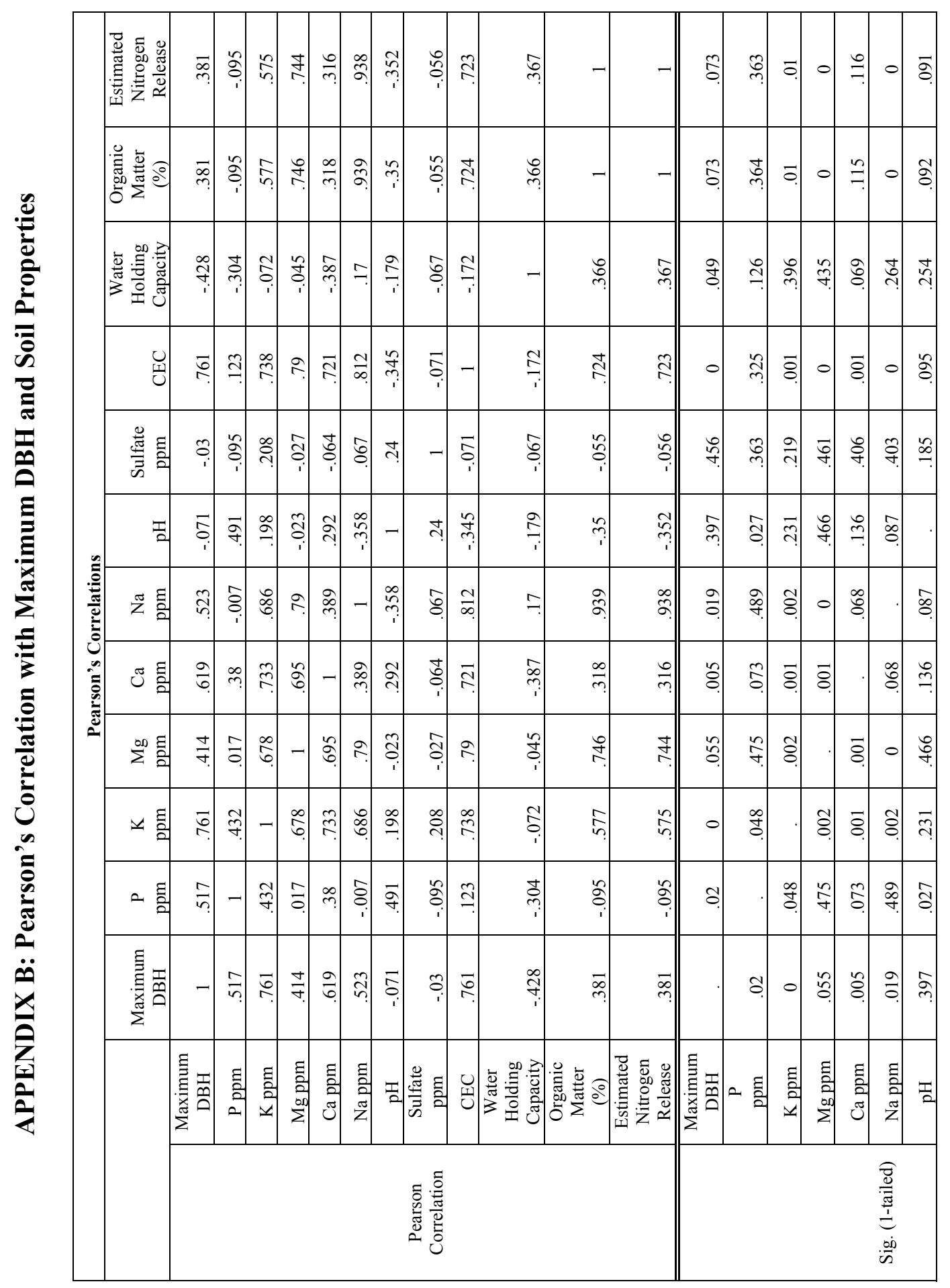




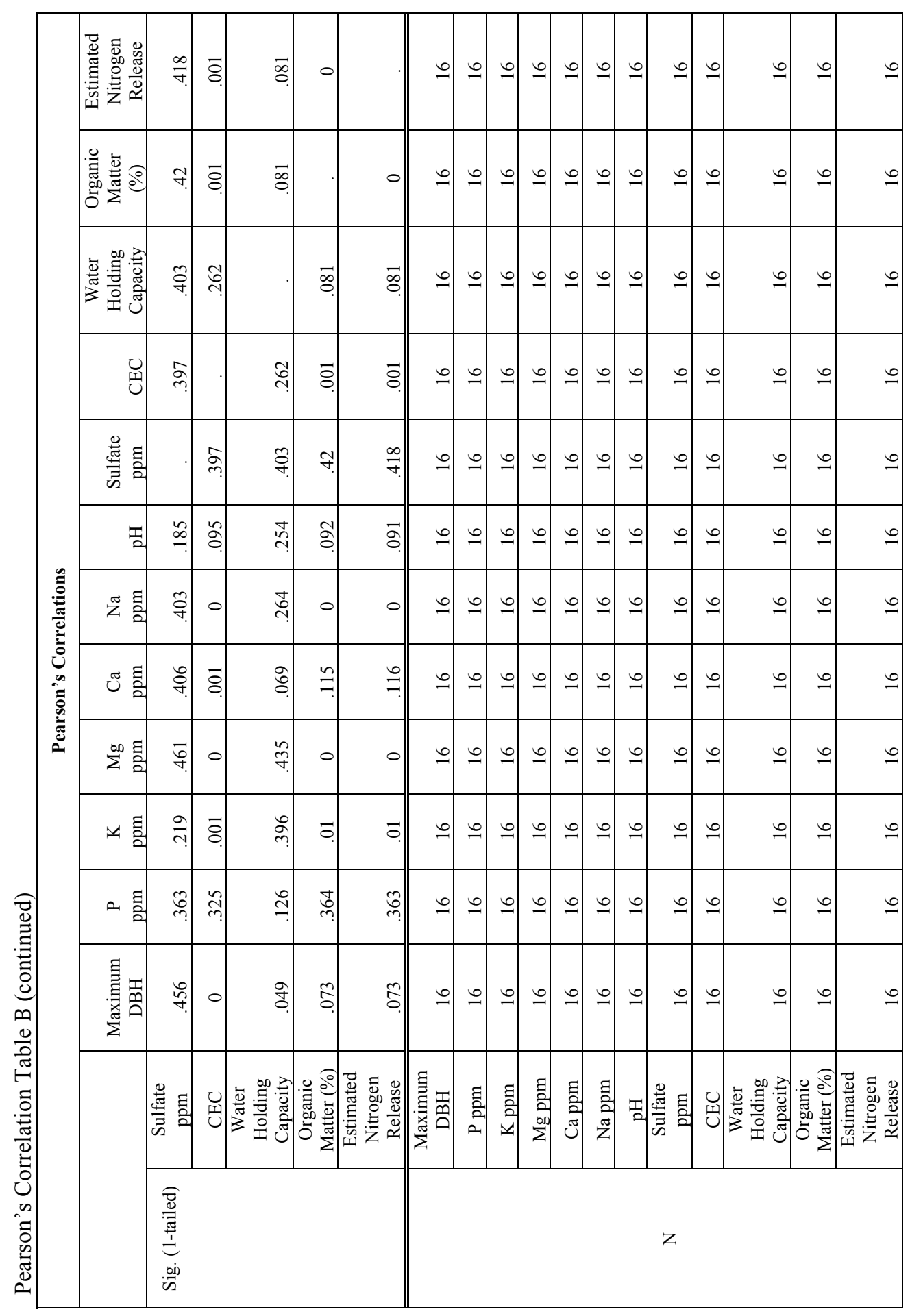




\begin{tabular}{|c|c|c|c|c|c|c|c|c|c|c|c|c|c|c|c|c|c|}
\hline & 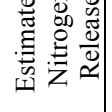 & ণิ & $\begin{array}{l}n \\
\vdots \\
i\end{array}$ & $\hat{n}$ & $\stackrel{f}{7}$ & \begin{tabular}{c|c}
0 & $\infty$ \\
$m$ & $\sigma$
\end{tabular} & ?. & \begin{tabular}{l}
0 \\
$\qquad$ \\
\hdashline
\end{tabular} & $\stackrel{\imath}{\imath}$ & : & - & - & $\bar{m}$ & ?ֶ? & o. & $0=$ & $\begin{array}{l}0 \\
\end{array}$ \\
\hline & 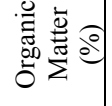 & $\stackrel{\infty}{\stackrel{\infty}{i}}$ & $\begin{array}{l}0 \\
0 \\
i \\
i\end{array}$ & $\hat{n}$ & $\stackrel{0}{\mathfrak{l}}$ & $\stackrel{\infty}{m} \mid \tilde{\sigma}$ & h. & ?. & 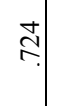 & $\begin{array}{l}: \\
: \\
? \\
?\end{array}$ & - & - & $\vec{m}$ & $\begin{array}{l}\text { ț } \\
\text { ?. }\end{array}$ & o. & $0 \%$ & $\begin{array}{lll}0 & 0\end{array}$ \\
\hline & 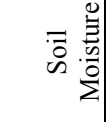 & $\tilde{\rho}$ & 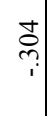 & 令 & $\begin{array}{l}0 \\
+ \\
\end{array}$ & 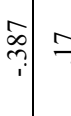 & ¿ & $\stackrel{0}{0}$ & \begin{tabular}{c}
1 \\
\\
\hdashline
\end{tabular} & - & $\begin{array}{l}\text { : } \\
\text { ?. }\end{array}$ & స్రి & f. & $\mid$ & ભి & $\stackrel{2}{q}$ & : \\
\hline & 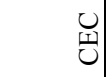 & $\stackrel{t}{\stackrel{m}{i}}$ & $\stackrel{?}{\beth}$ & $\stackrel{\infty}{\Re}$ & ? & 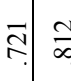 & $\stackrel{5}{4}$ & $\overrightarrow{0}$ & - & 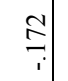 & $\stackrel{さ}{さ}$ & $\stackrel{?}{?}$ & $\stackrel{\Re}{\stackrel{0}{0}}$ & $\stackrel{\approx}{\approx}$ & $\overline{8}$ & $0 \bar{a}$ & 5 \\
\hline & 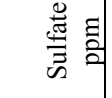 & $\because$ & $\begin{array}{l}n \\
o \\
i\end{array}$ & 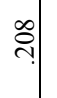 & तิ & 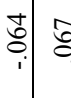 & 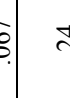 & - & $\overrightarrow{\vec{b}}$ & $\hat{8}$ & $\begin{array}{l}n \\
\hat{o} \\
i\end{array}$ & $\begin{array}{l}0.0 \\
\stackrel{0}{0} \\
0 \\
i\end{array}$ & $\stackrel{\widehat{o}}{\stackrel{p}{0}}$ & 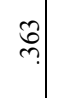 & $\stackrel{\vartheta}{\sim}$ & 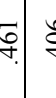 & 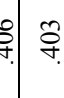 \\
\hline & a & อे & $\vec{q}$. & $\stackrel{\infty}{\stackrel{0}{=}}$ & 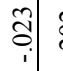 & 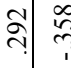 & - & $\stackrel{\unlhd}{\sim}$ & $\mid \begin{array}{c}2 \\
? \\
? \\
?\end{array}$ & $\stackrel{2}{7}$ & $\stackrel{m}{?}$ & $\begin{array}{c}1 \\
\text { ?. } \\
?\end{array}$ & 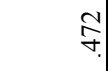 & $\widehat{\widehat{o}}$ & $\overrightarrow{\tilde{\vartheta}}$ & : & $\begin{array}{l}0 . \\
?:\end{array}$ \\
\hline 彦 & $\ddot{z} \bar{z}$ & $\stackrel{\text { }}{\stackrel{i}{i}}$ & $\hat{o}_{i}$ & : & $\vartheta$ & 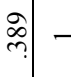 & $\ddot{c}$ & $\begin{array}{l}0 \\
0\end{array}$ & $\frac{7}{\infty}$ & 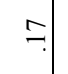 & ๙े. & $\stackrel{\infty}{\sim}$ & 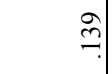 & 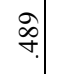 & ธิ & 0 & \\
\hline U & ฮూ & $\stackrel{\overbrace{}}{\stackrel{\leftrightarrow}{~}}$ & $\stackrel{\infty}{?}$ & $\stackrel{\overbrace{}}{\overbrace{}}$ & ộ. & $-\infty$ & ¿ & $\begin{array}{cc}t \\
0 \\
0\end{array}$ & $\overrightarrow{\mathrm{N}}$ & $\begin{array}{c}\hat{\infty} \\
? \\
i\end{array}$ & $\stackrel{\infty}{m}$ & $\stackrel{?}{m}$ & กี & $\mid \begin{array}{l}0 \\
0 \\
0\end{array}$ & $\overrightarrow{8}$ & 8 & $\stackrel{\circ}{\circ}$ \\
\hline 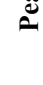 & $\sum^{\infty}$ & $\begin{array}{l}\stackrel{\circ}{\circ} \\
\stackrel{0}{1}\end{array}$ & 0 & 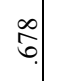 & - & ถู่ & $\tilde{c}$ & $\widehat{\widehat{c}}$ & $?$ & $\begin{array}{l}n \\
f \\
0 \\
i\end{array}$ & $\stackrel{0}{\stackrel{0}{7}}$ & $\underset{⿱}{\stackrel{+}{\sim} \|}$ & $\exists$ & $\mid \begin{array}{l}n \\
\mathfrak{f} \\
.\end{array}$ & ठे & $\bar{z}$ & 5 \\
\hline & $\checkmark$ ํํㄹ & 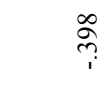 & $\stackrel{\overbrace{}}{ซ}$ & - & 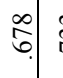 & $\stackrel{\overbrace{}}{\overbrace{}}$ & $\stackrel{\alpha}{0}$ & 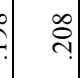 & $\stackrel{\infty}{\curvearrowright}$ & $\stackrel{\hat{o}}{i}$ & 点 & 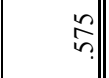 & t. & $\stackrel{\infty}{0}$ & & है: & కุ. \\
\hline & ค 虽 & & - & $\tilde{f}$ & ㅎ. & $\stackrel{\infty}{m}: \vec{\vdots}$ & $\bar{\sigma}$ & $\begin{array}{l}n \\
\vdots \\
i\end{array}$ & $\stackrel{\Omega}{\simeq}$ & 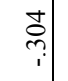 & $\begin{array}{l}n \\
o \\
\vdots \\
i\end{array}$ & $\begin{array}{l}0 \\
0 \\
i \\
i\end{array}$ & $\stackrel{\Omega}{=}$ & & $\stackrel{\infty}{0}$ & $\tilde{z}$ & 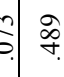 \\
\hline & 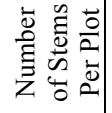 & - & $\stackrel{+}{\stackrel{\leftrightarrow}{n}}$ & $\stackrel{\infty}{\stackrel{\infty}{i}}$ & \begin{tabular}{l|l}
$\infty$ \\
$\stackrel{\infty}{0}$ \\
$\stackrel{1}{1}$
\end{tabular} & 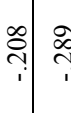 & $\frac{\circ}{c}$ & $\because$ & ?. & ఝీ. & ڤั) & ڤ્તે|l & & $\left|\begin{array}{l}\tilde{0} \\
.\end{array}\right|$ & \& & $\exists \approx$ & ज̦ \\
\hline & & 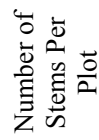 & 竞 & : & 춀 & 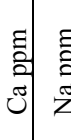 & 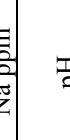 & 氙产 & : & 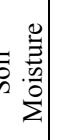 & 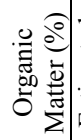 & 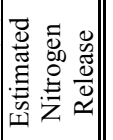 & 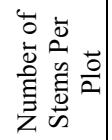 & 言 & 言 & 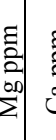 & 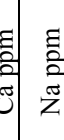 \\
\hline & & & & & & & $\begin{array}{l}\text { z: } \\
\text { o. } \\
\text { है }\end{array}$ & & & & & & & & & 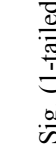 & \\
\hline
\end{tabular}




\begin{tabular}{|c|c|c|c|c|c|c|c|c|c|c|c|c|c|c|c|c|c|}
\hline & 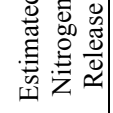 & $\overline{\mathrm{s}}$ & $\stackrel{\infty}{\vec{f}}$. & ฉे. & $\begin{array}{l}\overrightarrow{0} \\
\stackrel{0}{0}\end{array}$ & 0 & & 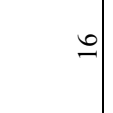 & - & $=1$. & $\div$ & 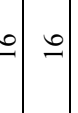 & -1 & -1 & $=\quad-$ & - & $\underline{0}$ \\
\hline & 总䓌 & ถุ. & ๆ. & $\bar{\Xi}$ & $\begin{array}{l}\vec{\infty} \\
\stackrel{0}{0}\end{array}$ & & o|| & $\stackrel{6}{-1}$ & $\simeq$ & $=1$ & -6 & $6=$ & -6 & -1 & 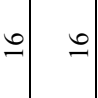 & 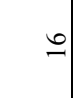 & $\stackrel{0}{\circ}$ \\
\hline & 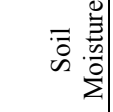 & ஸેّ & ช̂?. & స్రీ! & & $\begin{array}{c}\overrightarrow{0} \\
0\end{array}$ & sop.| & $\stackrel{0}{-1}$ & 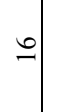 & $=$ & $\div$ & 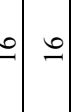 & 0 & -6 & $\stackrel{0}{-1}$ & $?$ & $\stackrel{\circ}{\circ}$ \\
\hline & $\begin{array}{l}0 \\
\text { 至 }\end{array}$ & ô. & ڤે. & & 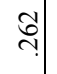 & $\bar{\Xi}$ & s.|. & 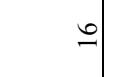 & $\simeq$ & $=$ & $\because \simeq$ & $=0$ & -9 & - & $\because \quad 0$ & 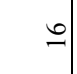 & $\underline{\square}$ \\
\hline & 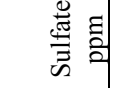 & 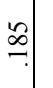 & & के & ồ. & ร. & $\stackrel{\infty}{\Rightarrow}$ & 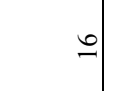 & 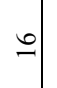 & $\underline{-1}$ & 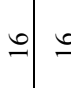 & $\begin{array}{c}2 \\
0\end{array}$ & 0 & 0 & 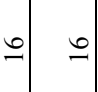 & $?$ & $\stackrel{\circ}{\circ}$ \\
\hline & 索 & & $\stackrel{\infty}{\simeq}$ & ọ. & 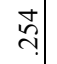 & ธิ & aे|| & $\stackrel{0}{2}$ & $\stackrel{-}{-}$ & 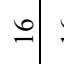 & 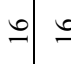 & $=0$ & - & -6 & 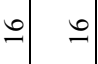 & $?$ & $\stackrel{\circ}{\circ}$ \\
\hline & z̃ & $\begin{array}{l}\hat{o} \\
0 \\
0\end{array}$ & ợ. & 0 & | & 0 & o|| & $\div$ & 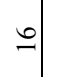 & $=$ & $\because 0$ & 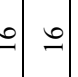 & 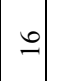 & - & 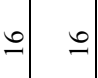 & 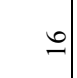 & $\stackrel{\circ}{\circ}$ \\
\hline & తే : & $\stackrel{0}{?}$ & ఫे & s. & 8 & $\cong$ & $\stackrel{?}{=}$ & 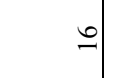 & 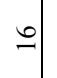 & ㅇ. & 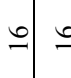 & 0 & 0 & - & 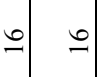 & 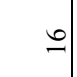 & 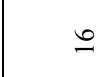 \\
\hline & $\sum^{\infty}$ 赔 & 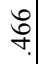 & $\overrightarrow{\vec{b}}$ & 0 & $\stackrel{\sim}{q}$ & 0 & ०| & 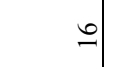 & - & $=1$. & $\because$ & 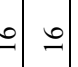 & 0 & -6 & \begin{tabular}{l|l}
- & -
\end{tabular} & 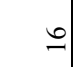 & $\stackrel{\circ}{\circ}$ \\
\hline & $\longleftarrow$ 형 & ণ़ & $\stackrel{\vec{े}}{0}$ & $\overline{\mathrm{s}}$ & ๗ి. & $\overline{0}$. & 0 & 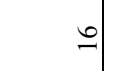 & - & $\stackrel{-}{-1}$ & $\because$ & 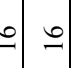 & - & 0 & $\because \quad-\quad$ & 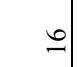 & $\stackrel{\circ}{-}$ \\
\hline & a 형 & 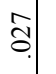 & $\stackrel{\overbrace{}}{?}$ & $\stackrel{n}{n}$ & $\begin{array}{l}0 \\
\nearrow\end{array}$ & 常 & గ్రి| & 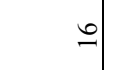 & 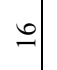 & $\stackrel{0}{-}$ & $\div$ & 6 & 0 & $\stackrel{\circ}{-}$ & 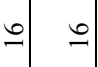 & $=$ & $\stackrel{\circ}{\circ}$ \\
\hline & 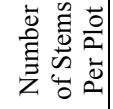 & ปิ & 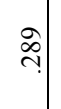 & مُ. & 守. & $\vec{m}$ & $\vec{m}$ & $\simeq$ & 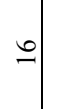 & $=1$. & $=0$ & $\begin{array}{c}6 \\
0\end{array}$ & 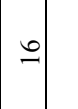 & $\stackrel{0}{-}$ & \begin{tabular}{l|l}
- & -
\end{tabular} & -6 & $\stackrel{0}{\circ}$ \\
\hline & & 稀 & हू & & : & : & 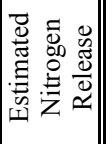 & 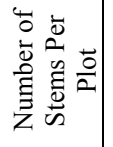 & 章 & 咅: & 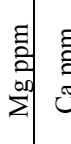 & 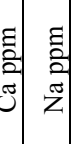 & 氙愛 & 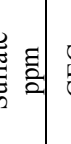 & 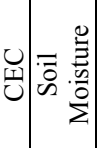 & 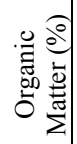 & 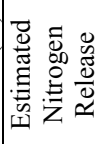 \\
\hline & & & 离 & & & & & & & & & & z & & & & \\
\hline
\end{tabular}




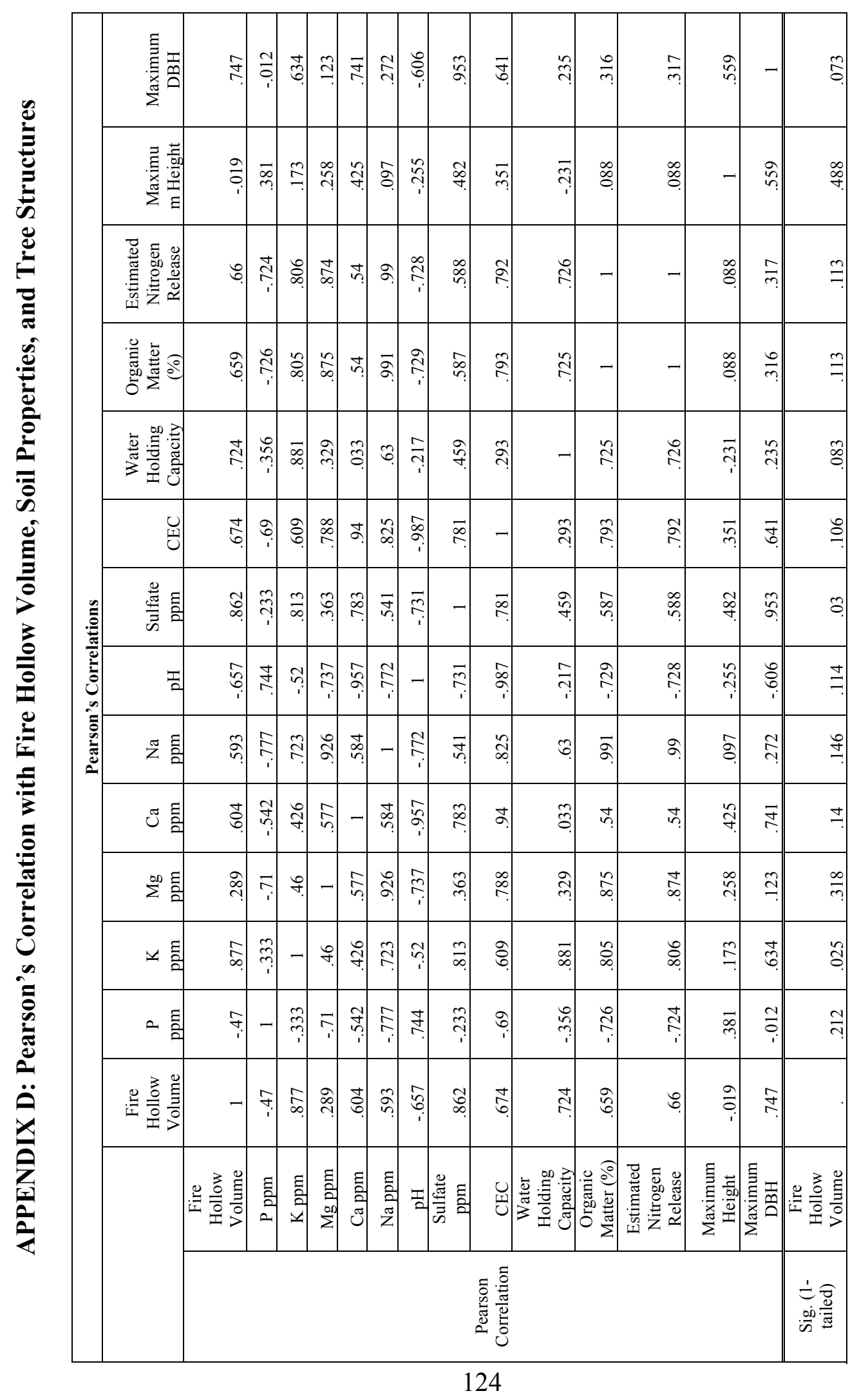




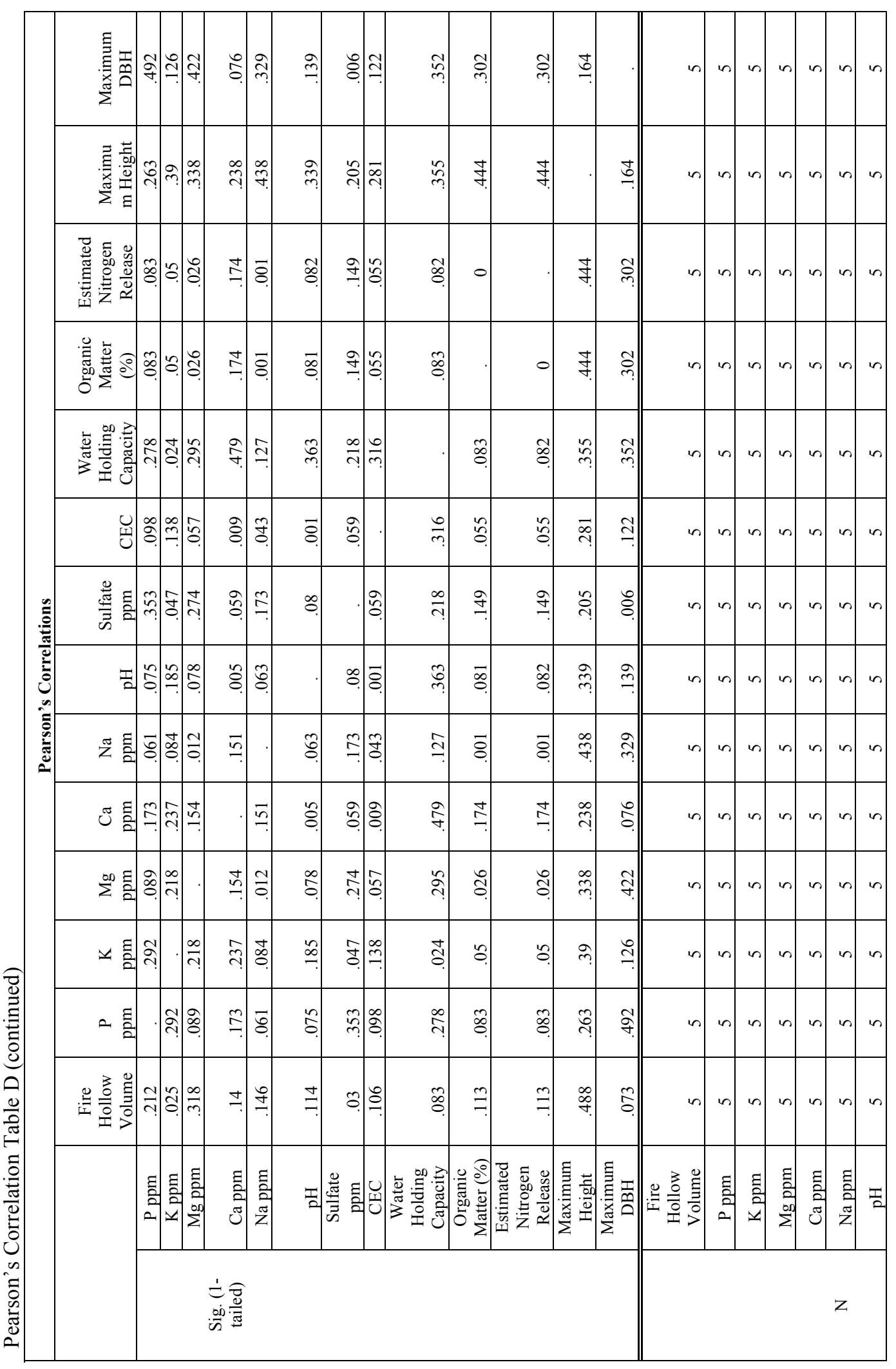




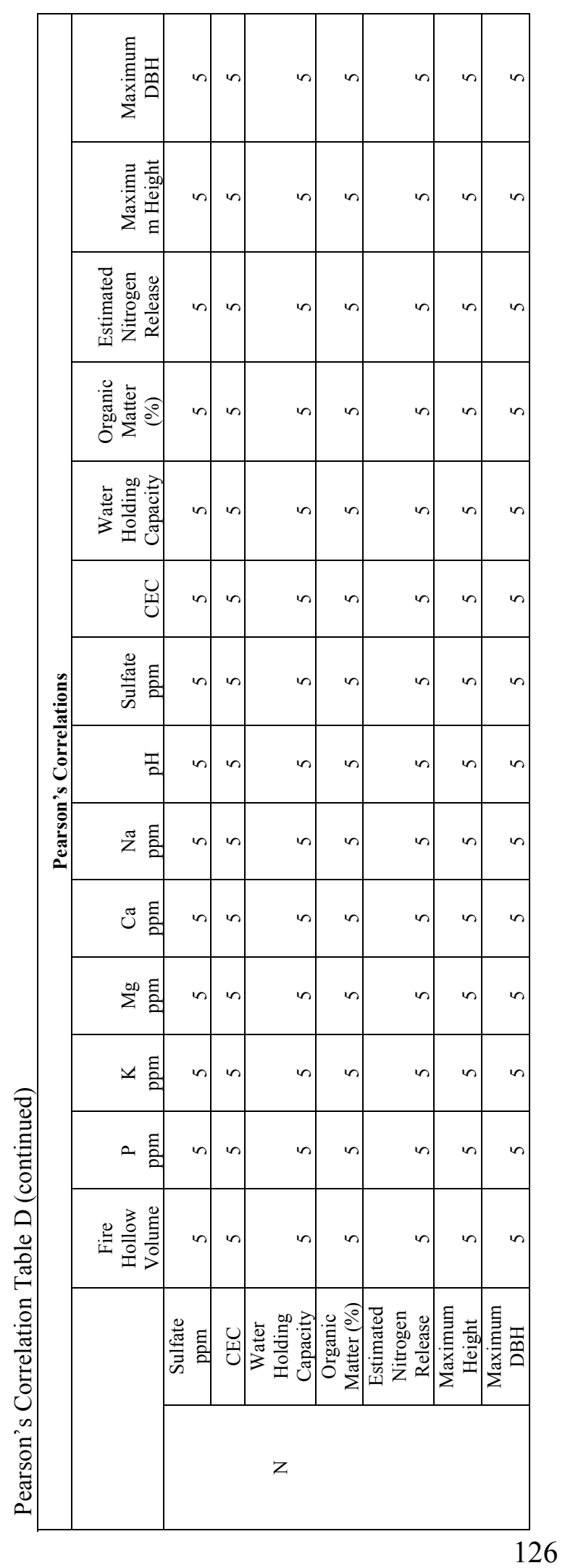




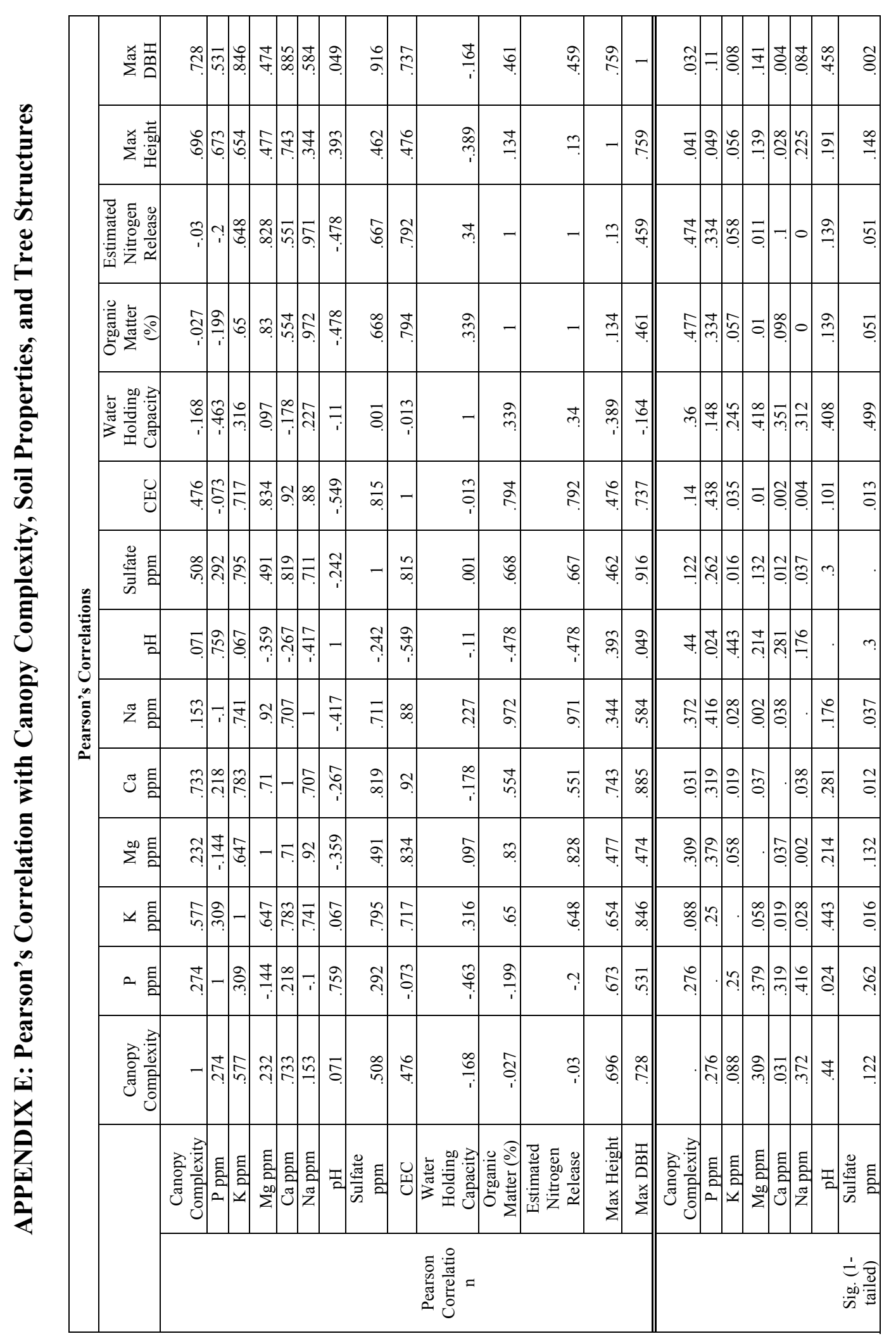




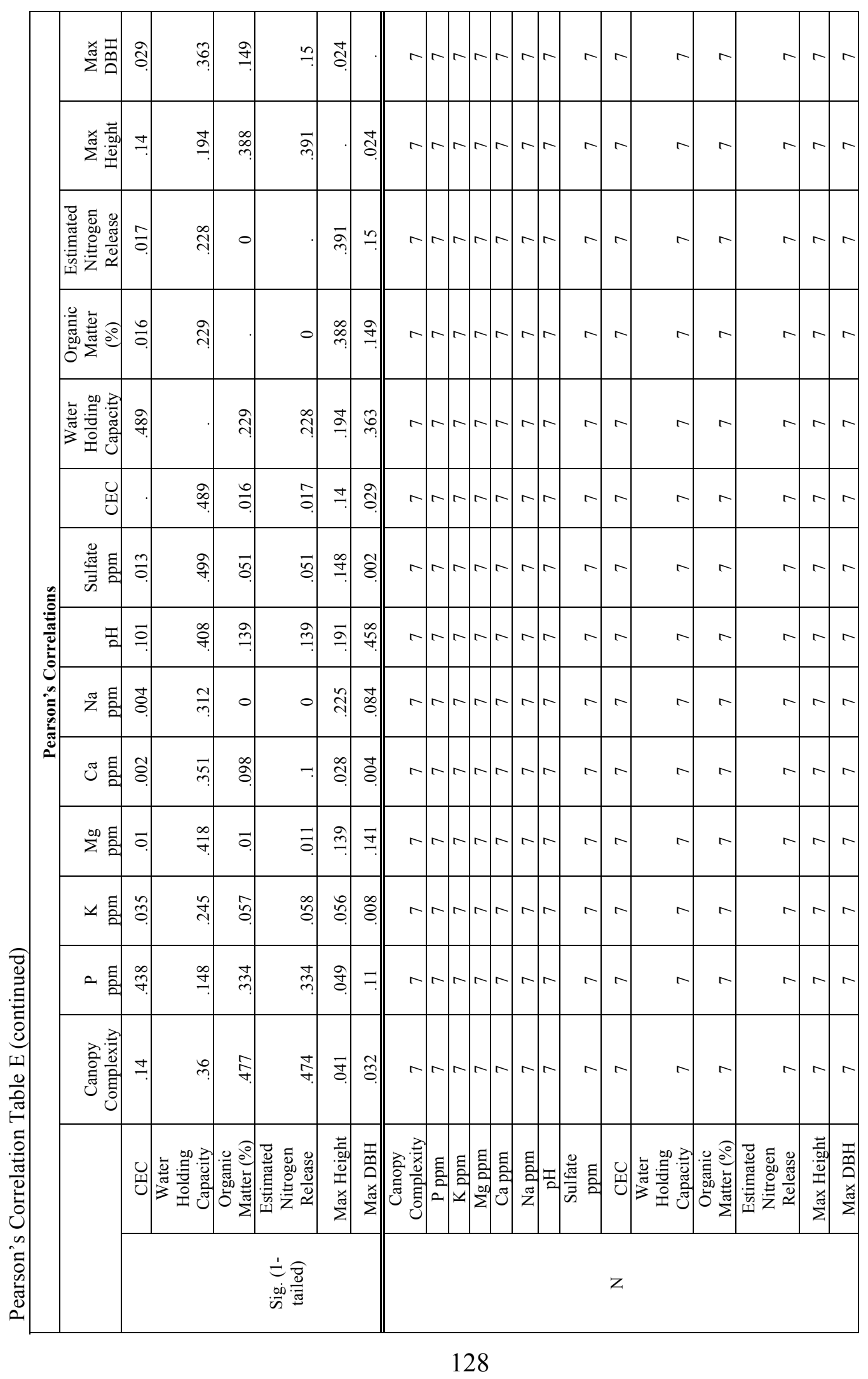

